\title{
Flora da Bahia: Iridaceae
}

\author{
Pâmela Novais de Oliveira ${ }^{1^{*}}$, Ana Maria Giulietti ${ }^{1,2, a}$ \& Reyjane Patrícia de Oliveira ${ }^{1, b}$ \\ ${ }^{1}$ Programa de Pós-Graduação em Botânica, Departamento de Ciências Biológicas, Universidade Estadual de \\ Feira de Santana, Feira de Santana, Bahia, Brasil. \\ ${ }^{2}$ Instituto Tecnológico VALE de Desenvolvimento Sustentável, Belém, Pará, Brasil.
}

\begin{abstract}
Resumo - É apresentado o tratamento taxonômico da família Iridaceae para o estado da Bahia, Brasil. São reconhecidas 24 espécies, distribuídas em sete gêneros: Alophia (A. drummondii), Cipura (2 espécies), Eleutherine (E. bulbosa), Neomarica (8), Pseudiris (P. speciosa), Sisyrinchium (4) e Trimezia (7). Sete espécies são endêmicas da Bahia. São apresentados chaves de identificação, descrições, comentários taxonômicos e ecológicos, ilustrações e mapas de distribuição das espécies no estado.
\end{abstract}

Palavras-chave adicionais: florística, Iridoideae, Nordeste do Brasil, taxonomia.

Abstract (Flora of Bahia: Iridaceae) - The taxonomic treatment of the Iridaceae from Bahia state, Brazil, is presented. Twenty-four species and seven genera are recognised: Alophia (A. drummondii), Cipura (2 species), Eleutherine (E. bulbosa), Neomarica (8), Pseudiris (P. speciosa), Sisyrinchium (4) and Trimezia (7). Seven species are endemic to Bahia. Identification keys, descriptions, taxonomic and ecological comments, illustrations and distribution maps of the species in Bahia are presented.

Additional key words: floristics, Iridoideae, Northeast Brazil, taxonomy.

\section{IRIDACEAE}

Ervas com caule subterrâneo em cormo, rizoma ou bulbo; cormos ou bulbos, se presentes, com catafilos fibrosos ou membranáceos, de cor castanha a vermelha ou púrpura. Folhas unifaciais, equitantes, dísticas ou espiraladas, cilíndricas ou planas, lineares a ensiformes, plicadas ou não, paralelinérvias, invaginantes na base. Escapos cilíndricos ou achatados, áfilos ou portando uma a muitas brácteas foliáceas em sua extensão. Inflorescências em ripídios ou espigas, terminais ou axilares, pedunculadas ou sésseis. Flores vistosas, efêmeras, trímeras, diclamídeas; tépalas livres ou conatas, petaloides, as externas e internas iguais ou bem diferenciadas entre si; estames 3 , opostos às tépalas externas, filetes livres ou conatos, às vezes adnatos ao perianto; anteras lineares, oblongas ou sagitadas, rimosas ou raramente poricidas; ovário ínfero, geralmente trilocular, raro unilocular, pluriovulado, placentação axilar ou raramente parietal; estiletes 3, livres ou unidos, muitas vezes petaloides, estigmas inteiros a profundamente divididos, apicais ou laterais. Frutos cápsulas loculicidas; sementes globosas a obovais, elípticas ou piramidais.

Iridaceae pertence à ordem Asparagales (APG IV 2016). Inclui 66 gêneros e cerca de 2030 espécies, com distribuição cosmopolita e centro de diversidade na África do Sul, seguido pela América do Sul (Goldblatt et al. 2008). No Brasil, são referidos 23 gêneros, sendo dois endêmicos, Pseudotrimezia R.C.Foster e Pseudiris Chukr \& A.Gil, e 190 espécies, 106 endêmicas (Eggers

\footnotetext{
*Autora para correspondência: pam_lhug@hotmail.com;

aanagiulietti@hotmail.com; brpatricia@uefs.br

Editor responsável: Alessandro Rapini

Submetido: 31 maio 2016; aceito: 22 nov. 2016

Publicação eletrônica: 19 dez. 2016; versão final: 20 dez. 2016
}

et al. 2016). Suas espécies se distribuem da Amazônia ao Rio Grande do Sul, sendo encontradas principalmente em áreas de floresta atlântica, cerrado, campos rupestres e nos campos do sul (Eggers 2008). Algumas espécies têm grande importância como plantas ornamentais, sendo no Brasil destacadas as espécies dos gêneros Trimezia Salisb. ex Herb. e Neomarica Sprague (Lorenzi \& Sousa 1999).

Para a Bahia, foram reconhecidos sete gêneros e 24 espécies: Alophia (A. drummondii), Cipura (2 espécies), Eleutherine (E. bulbosa), Neomarica (8), Pseudiris (P. speciosa), Sisyrinchium (4) e Trimezia (7); sete delas são endêmicas do estado.

Chave para os gêneros (para representações das estruturas reprodutivas, veja as Figuras 1 e 2)

1. Caule subterrâneo tipo bulbo, coberto por catafilos membranáceos; folhas plicadas.

2. Flores brancas, tépalas externas e internas subiguais; catafilos avermelhados ou purpúreos

3. Eleutherine

2'. Flores amarelas, azuis ou roxas, tépalas externas e internas desiguais; catafilos castanhos.

3. Tépalas internas patentes; anteras panduriformes, com conectivo amplo

1. Alophia

3'. Tépalas internas eretas; anteras lineares, com conectivo delgado

2. Cipura

1'. Caule tipo cormo, coberto por catafilos fibrosos, ou rizoma conspícuo ou inconspícuo; folhas não plicadas.

4. Tépalas externas e internas subiguais; estames alternos aos estiletes 6. Sisyrinchium

4'. Tépalas externas e internas desiguais; estames opostos e adpressos aos estiletes.

5. Rizoma; folhas equitantes; escapo achatado .. 
5'. Cormo; folhas espiraladas; escapo cilíndrico ou elíptico.

6. Tépalas internas com estrias longitudinais; ramos do estilete com 2 cristas estigmáticas petaloides; anteras azuis .......

5. Pseudiris

6'. Tépalas internas com estrias transversais; ramos do estilete com (2)3 cristas estigmáticas cuspidadas ou truncadas; anteras amarelas, esverdeadas ou marrons

7. Trimezia

\section{Alophia Herb.}

Ervas com bulbo envolto por catafilos membranáceos, castanhos. Folhas espiraladas, planas ou cilíndricas, lineares ou linear-ensiformes, plicadas. Escapo simples ou pouco ramificado, portando 1-4 brácteas em sua extensão. Ripídios terminais, laxos, pedunculados; espatas membranáceas. Flores brancas ou roxas; tépalas desiguais, as externas maiores, obovais a oboval-elípticas, patentes, com estrias transversais na base, as internas menores, obovais a oboval-elípticas, patentes, com estrias transversais na região mediano-basal; filetes livres ou parcialmente unidos, filiformes, glabros, anteras panduriformes, alternas, adpressas aos estiletes, com conectivo amplo, tecas posicionadas lateralmente nos bordos do conectivo; ovário oval a oboval, glabro, estiletes unidos na região mediano-basal, livres no ápice, divergindo entre ou acima das anteras, ramos profundamente divididos em dois braços filiformes, reflexos, estigmas apicais, globosos. Cápsulas obovoides a cilíndricas, ápice truncado, glabras; sementes globosas a obovais.

Alophia compreende cinco espécies, distribuídas desde o sul dos Estados Unidos até a América do Sul, na Guiana e Brasil (Goldblatt \& Manning 2008). No Brasil, está representado por duas espécies, A. medusa (Baker) Goldblatt em Goiás e A. drummondii na Região Nordeste (Eggers et al. 2016).

\subsection{Alophia drummondii (Graham) R.C.Foster,} Contr. Gray Herb. 155: 34. 1945.

Figuras 3, 4 e 23A, B.

Nomes populares: alho-brabo e alho-do-mato.

Ervas $12-75 \mathrm{~cm}$ alt.; bulbos $1,2-4 \times 0,7-2,5 \mathrm{~cm}$. Folhas $1-3$ por planta, $20-51 \times 0,2-1 \mathrm{~cm}$, lineares a linear-ensiformes, membranáceas. Escapo $9-52 \mathrm{~cm}$ compr., simples ou ramificado, portando 1-3 brácteas lineares a linear-ensiformes, a primeira bráctea $9-48 \times$ $0,3-1,4 \mathrm{~cm}$, as demais $2,5-5,5 \times 0,2-0,4 \mathrm{~cm}$, separadas por entrenós de 0,8-7 cm compr. Ripídios 1-10, laxos; pedúnculo 1,5-9,5 cm compr.; espatas 1,5-6,5 × 0,4 $1,4 \mathrm{~cm}$. Flores roxas; tépalas externas obovais, $1-2,5 \times$ $0,7-1,5 \mathrm{~cm}$, ápice arredondado a truncado, região mediano-basal amarelada com estrias castanhovináceas; tépalas internas $1-1,5 \times 0,5-0,8 \mathrm{~cm}$, involutas, ápice arredondado, região basal amarelada com estrias castanho-vináceas, região mediana esbranquiçada com estrias roxas, podendo conter duas máculas amarelo-intensas na concavidade interna mediana; filetes roxos, $0,2-0,5 \mathrm{~cm}$ compr., unidos na base, anteras roxas, $0,4-0,8 \mathrm{~cm}$ compr; ovário $4-5 \mathrm{~cm}$ compr., oval, estiletes roxos, $0,8-1$ compr., unidos até ca. $0,6 \mathrm{~cm}$ compr., base cilíndrica, região mediana alargada, ramos divididos em dois braços filiformes, $0,1-0,3 \mathrm{~cm}$ compr. Cápsulas oblongas, $1,5-3 \times 0,8-$ $1,2 \mathrm{~cm}$; sementes ca. $0,3 \times 0,2 \mathrm{~cm}$.

Apresenta distribuição disjunta entre as regiões áridas do sul dos Estados Unidos até o oeste do México e a América do Sul (Goldblatt \& Manning 2008). No Brasil, ocorre nos estados de Alagoas, Ceará, Paraíba (Alves et al. 2011), Pernambuco (Eggers et al. 2016), sendo registrada pela primeira vez para o Maranhão, Piaú, Rio Grande do Norte e Bahia a partir deste estudo. A8, B5, B7, B8, B9, C5, C8/9, D4, D5, D6, D8, D9, F3, F7, G4, G7: caatinga e floresta estacional semidecidual. Encontrada com flores de dezembro a agosto e com frutos de março a abril. As flores se abrem às 6:00 horas da manhã e se fecham por volta das 11:00 horas.

Material selecionado - Cariranha, a $1 \mathrm{~km}$ do rio Carinhanha, $14^{\circ} 18^{\prime} 41^{\prime \prime S}, 43^{\circ} 48^{\prime} 32^{\prime \prime} \mathrm{W}, 28 \mathrm{dez}$. 2007, M.L. Guedes \& F.S. Gomes

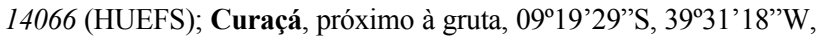
13 mar. 2011, E. Melo et al. 9416 (HUEFS); Euclides da Cunha, 20 mar. 2004, M.L. Guedes et al. 10901 (ALCB); Gentio do Ouro, $11^{\circ} 07^{\prime} \mathrm{S}, 42^{\circ} 07^{\prime} \mathrm{W}, 23$ fev. 1977, R.M. Harley 18978 A (CEPEC, MBM, SPF, UEC); Itapicuru, $3 \mathrm{~km}$ de Itapicuru, BA-402 para Olindina, 1 abr. 1976, G. Davidse \& W.G. D'Arcy 11784 (SP); Jaguarari, Parque, $08^{\circ} 38^{\prime} 52^{\prime \prime}$ 'S, 39'23'13'W, 2 abr. 2009, E. Melo et al. 6197 (HUEFS); Juazeiro, estrada para Sobradinho, $4 \mathrm{~km}$ antes da bifurcação para Junco, $09^{\circ} 31^{\prime} 54^{\prime \prime S}, 40^{\circ} 34^{\prime} 08^{\prime \prime} \mathrm{W}, 7$ jul. 2009, $J$. Paula-Souza et al. 9924 (HVASF); Maracás, fazenda Tanquinho, 20 jan. 1981, L.P. Queiroz \& M.L. Guedes 70 (ALCB); Morpará, caminho para fazenda Ema, ca. $3 \mathrm{~km}, 11^{\circ} 33^{\prime} \mathrm{S}, 43^{\circ} 16^{\prime} \mathrm{W}, 22 \mathrm{jan} .2001$, M.L. Guedes \& D. Paulo Filho 7815 (ALCB, CEPEC, HUEFS); Morro do Chapéu, fazenda São João Brejões, rio Salitre,

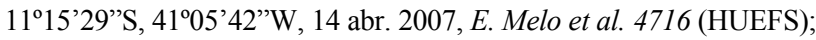
Paulo Afonso, aldeia Serrota, $09^{\circ} 29^{\prime} \mathrm{S}, 38^{\circ} 05^{\circ} \mathrm{W}, 16$ jun. 2006, $M$. Colaço 174 (HUEFS); Pilão Arcado, "Lú Pequeno", ca. 55 km W de Pilão Arcado, na estrada para Brejo de Zacarias, $10^{\circ} 06^{\prime} 25^{\prime \prime}$ 'S, 42'51'32”W, 19 mar. 2006, E.B. Souza et al. 1582 (HUEFS, HUESC); Poções, rodovia BR-116, trecho Poções-Jequié, a 34 km de Poções, 5 mar. 1978, S.A. Mori et al. 9543 (CEPEC); Remanso, caminho para Pau Ferro, 09 $38^{\prime} 44^{\prime \prime}$, 42 $42^{\circ} 14^{\prime} 05^{\prime \prime} \mathrm{W}, 27$ fev. 2000, G. Cavalcanti et al. 4 (ALCB, HUEFS, HUESC, SPF); Riachão das Neves, estrada para o aterro sanitário, $13^{\circ} 46^{\prime} 49^{\prime \prime} \mathrm{S}, 44^{\circ} 54^{\prime} 39^{\prime \prime} \mathrm{W}, 5$ abr. 2005, J.G. Carvalho-Sobrinho et al. 436 (HUEFS); Santo Inácio, entrada a ca. $1 \mathrm{~km}$ do entroncamento para Santo Inácio, estrada de chão em direção a uma queda d'água, $11^{\circ} 05^{\prime} 25^{\prime \prime} \mathrm{S}, 42^{\circ} 42^{\prime} 31^{\prime \prime} \mathrm{W}, 16$ maio 2002, T.S. Nunes et al. 966 (HUEFS); Serrinha, próximo à Torre da Embratel, povoado Barra do Vento, 11051'79"S, $38^{\circ} 01^{\prime} 99^{\prime \prime} \mathrm{W}, 5$ ago. 2014, P.N. Oliveira et al. 122 (HUEFS).

Material adicional - BRASIL. CEARÁ: Brejo Santo, Barragem do Reservatório Porcos, 07³5'22'S, 38 $8^{\circ} 51^{\prime} 56^{\prime}$ 'W, 17 abr. 2013, F.F.S. Silva 791 (HUVASF). MARANHÃO: Barão do Grajaú, ca. $10 \mathrm{~km}$ da cidade na BR-230, $06^{\circ} 43^{\prime} 54^{\prime} \mathrm{S}, 43^{\circ} 05^{\prime} 08^{\prime}$ 'W, 25 jan. 2012, R.M. Harley et al. 56451 (HEUFS). PARAÍBA: 

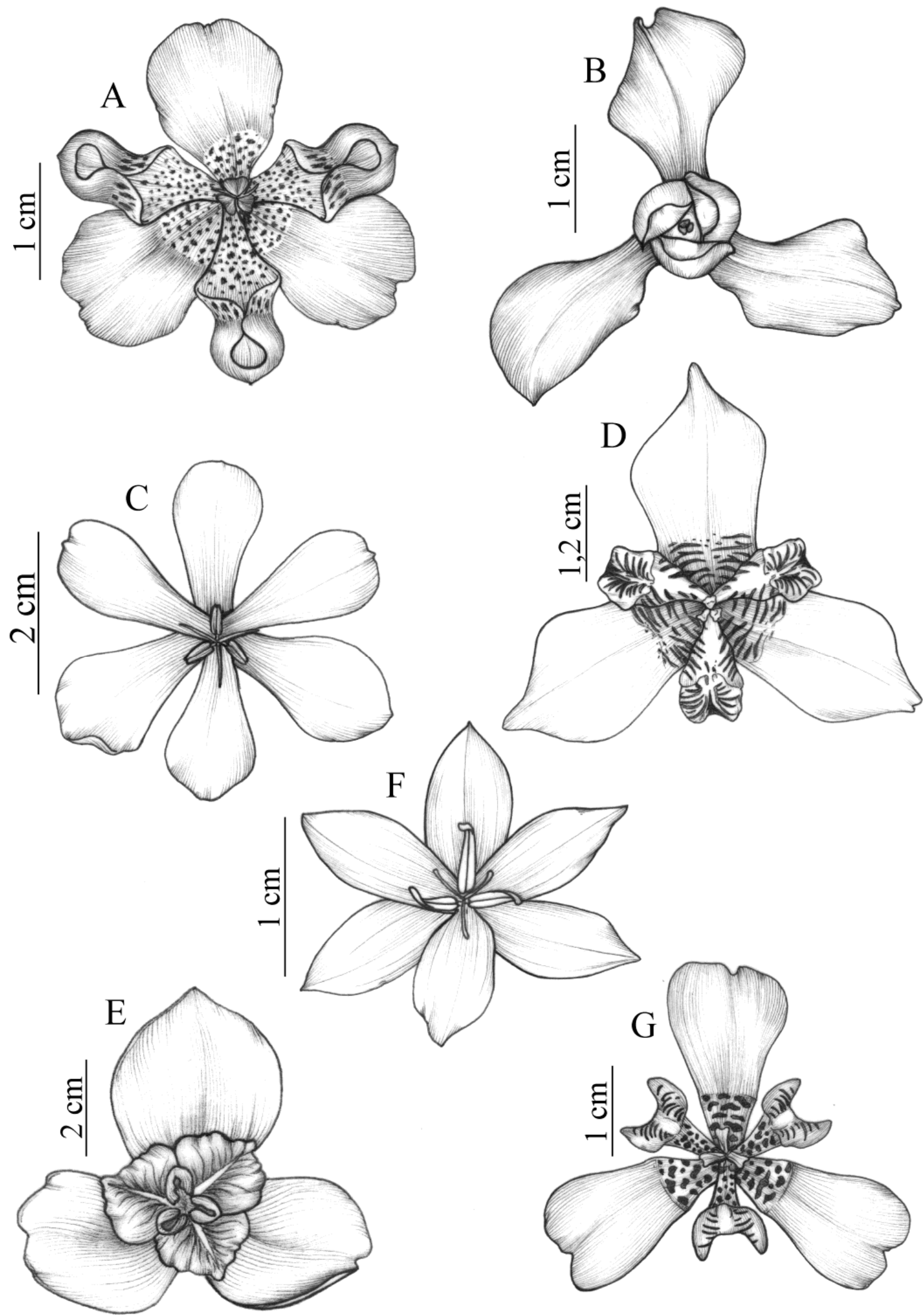

Figura 1. Flores de representantes dos gêneros de Iridaceae encontrados no estado da Bahia. A- Alophia drummondii; B- Cipura paludosa; C- Eleutherine bulbosa; D- Neomarica portosecurensis; E- Pseudiris speciosa; F- Sisyrinchium vaginatum; G- Trimezia caulosa. (A- Oliveira 122 HUEFS; B- Popovkin 614 HUEFS; C- Popovkin 1122 HUEFS; D- Gil 156 UEC; E - Cardoso 434 HUEFS; F- Oliveira 112 HUEFS; G- Oliveira 115 HUEFS). 

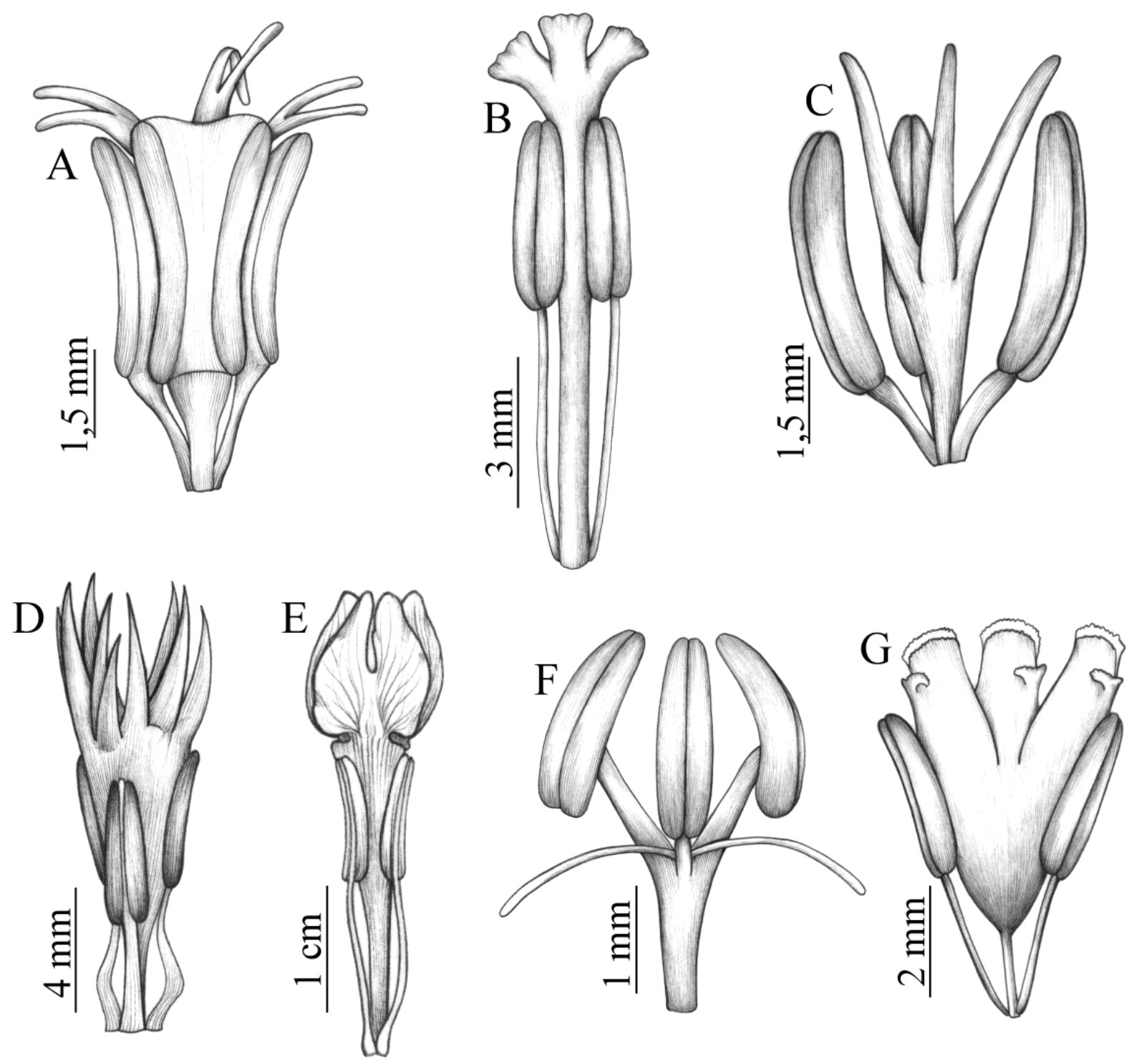

Figura 2. Estames e estiletes de representantes dos gêneros de Iridaceae encontrados no estado da Bahia. A- Alophia drummondii; B- Cipura paludosa; C- Eleutherine bulbosa; D- Neomarica portosecurensis; E- Pseudiris speciosa; F- Sisyrinchium vaginatum; G- Trimezia caulosa. (A- Oliveira 122 HUEFS; B- Popovkin 614 HUEFS; C- Popovkin 1122 HUEFS; D- Gil 156 UEC; E- Cardoso 434 HUEFS; F- Oliveira 112 HUEFS; G- Oliveira 115 HUEFS).

Monteiro, sítio Olho D’água do Silva, 0752'30”S, 37¹3'44”W, 9 jul. 2009, J.A. Siqueira-Filho et al. 2182 (HUVASF). PIAUÍ: Morro

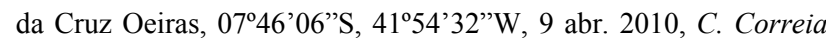
539 (HUEFS). RIO GRANDE DO NORTE: Jucurutu, RPPN Stoessel de Britto, 4 jun. 2008, A.A. Roque 613 (HUEFS, UFRN); Serra Negra do Norte, Estação Ecológica do Seridó, Trilha Norte, 06 34'35"S, 37015'08'W, 22 maio 2006, R.T. Queiroz 868 (HUEFS, UFRN).

Alophia drummondii apresenta flores com anteras panduriformes, com amplo conectivo, posicionando as tecas lateralmente nas bordas da antera, e estiletes com ramos profundamente divididos em dois braços filiformes, reflexos. No material selecionado neste trabalho, foi observada variação quanto ao porte dos indivíduos e tamanho das estruturas, incluindo bulbo, folhas, escapos, brácteas, flores e frutos. A espécie é, muitas vezes, equivocadamente identificada como
Calydorea gardneri Baker, possivelmente devido à semelhança da porção vegetativa entre os indivíduos de menor porte de $A$. drummondi e os de $C$. gardneri. Contudo, as duas espécies podem ser diferenciadas pela morfologia dos estames e estiletes. Calydorea gardneri distingue-se de A. drummondi por apresentar anteras lineares, reflexas, e estiletes unidos em quase todo o seu comprimento, com pequena porção apical dividida em três ramos lineares e indivisos (Goldblatt \& Henrich 1991). Alophia drummondii também é erroneamente identificada como A. linearis (Kunth) Klatt. Esta confusão decorre da indicação do material Blanchet 2741 no Herbário K como tipo de $A$. linearis, informação mantida por Eggers et al. (2016) na Flora do Brasil. Contudo, uma análise acurada do material revelou que a exsicata é, na verdade, de $A$. drummondii. Alophia linearis, tratada como Larentia 


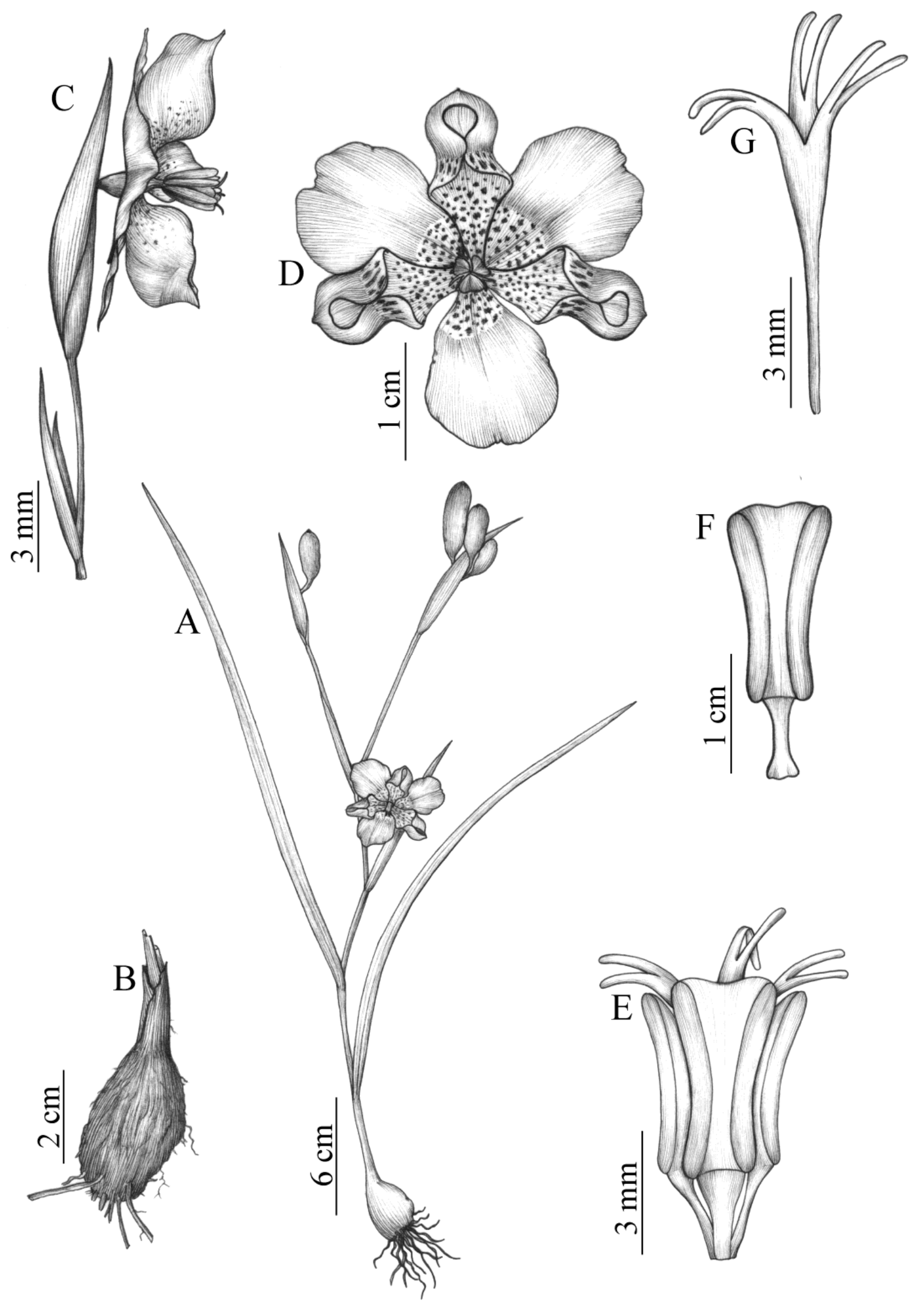

Figura 3. A-G. Alophia drummondii: A- hábito; B- bulbo; C- ripídio com flor, vista lateral; D- flor, vista frontal; E- estames e estiletes; F- estame; G- estilete. (A- Melo 4716 HUEFS; B-G- Oliveira 122 HUEFS). 
linearis (Kunth) Klatt, ocorre em áreas de cerrado na Região Centro-Oeste (Eggers et al. 2016) e apresenta anteras sem conectivo visível, lineares, adpressas aos ramos do estilete apenas na porção apical das tecas (Goldblatt \& Manning 2008).

\section{Cipura Aubl.}

Ervas com bulbo envolto por catafilos membranáceos, castanhos, entremeados por resina. Folhas espiraladas, planas, lineares a linearensiformes, plicadas. Escapo cilíndrico, portando uma bráctea terminal, lanceolada, plicada. Ripídios axilares, congestos, sésseis ou subsésseis; espatas membranáceas. Flores azuis, brancas ou amarelas; tépalas subiguais ou desiguais, as externas maiores, obovais a oblanceoladas, reflexas ou patentes, as internas oboval-oblongas, eretas, côncavas, revolutas ou involutas, escondendo total ou parcialmente os estames e estiletes; filetes livres, filiformes, glabros, anteras lineares, alternas ou opostas aos estiletes; ovário oblongo, glabro, estiletes unidos na região mediano-basal, livres no ápice, ramos truncados ou com 2-4 lacínios, região estigmática na face interna dos lacínios. Cápsulas oblongas a ovoides, truncadas; sementes globosas.

Cipura inclui oito espécies, distribuídas da América Central a América do Sul (Goldblatt et al. 2008). Na América do Sul, ocorre na Guiana Francesa, Guiana, Bolívia, Peru, Colômbia e Brasil, em ambientes úmidos ou em cerrados (Chukr \& Capellari Jr. 2003). No Brasil, o gênero está representado por quatro espécies (Eggers et al. 2016), sendo duas representadas na Bahia.

\section{Chave para as espécies}

1. Flores azuis; tépalas internas escondendo totalmente os estames e estiletes; ramos dos estiletes truncados ..................... 2.1. C. paludosa

1 '. Flores amarelas; tépalas internas escondendo parcialmente os estames e estiletes; ramos dos estiletes com quatro lacínios agudos

\subsection{C. xanthomelas}

2.1. Cipura paludosa Aubl., Hist. P1. Guiane 1: 38; t. 13. 1775.

Figuras 5A-D, 6 e 23C-E.

Ervas $10-30 \mathrm{~cm}$ alt.; bulbos $1,2-2 \times 0,8-1,7 \mathrm{~cm}$. Folhas 1-4 por planta, $16-32 \times 0,3-2 \mathrm{~cm}$, linearensiformes, membranáceas. Escapo $4-13 \mathrm{~cm}$ compr., ápice portando uma bráctea foliácea, linear-ensiforme, de 10,5-39 × 0,3-0,6 cm. Ripídios 1-6, sésseis a curto-pedunculados; pedúnculos até $1 \mathrm{~cm}$ compr.; espatas 2,5-4,5 $\times 0,6-1 \mathrm{~cm}$. Flores azuis; tépalas externas obovais, $1-3 \times 0,5-1,5 \mathrm{~cm}$, patentes ou eretas, ápice arredondado a cuneado, região basal com margem reflexa; tépalas internas oboval-elípticas, 0,6$1 \times 0,4-0,6 \mathrm{~cm}$, eretas, escondendo totalmente os estames e estiletes, ápice arredondado, revoluto, região

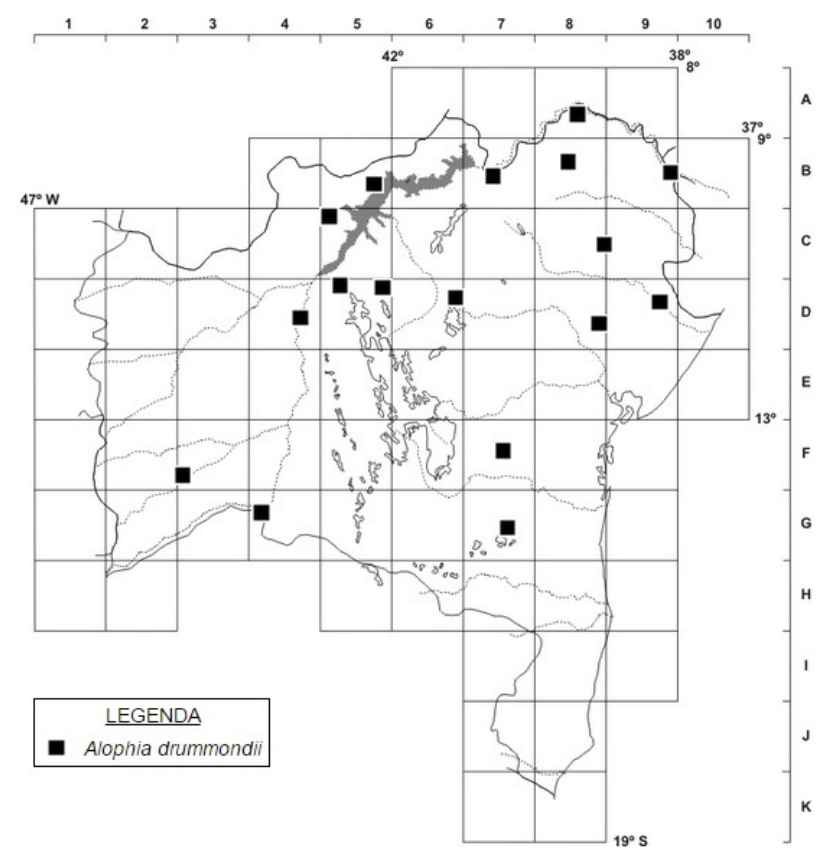

Figura 4. Mapa de distribuição de Alophia drummondii no estado da Bahia.

mediana com estria longitudinal amarela; filetes azuis, 0,25-0,5 cm compr., anteras brancas, ca. 0,3 cm compr; ovário $0,8-1 \times 0,1-0,2 \mathrm{~cm}$, estiletes azuis, $0,7-$ $1,3 \mathrm{~cm}$ compr., unidos até $0,4-0,9 \mathrm{~cm}$ compr., ramos truncados. Cápsulas elipsoides, $1,4-2,5 \times 0,6-0,8 \mathrm{~cm}$; sementes $0,13-0,15 \times$ ca. $0,1 \mathrm{~cm}$.

Amplamente distribuída na América tropical, desde o sul do México até o sudeste do Brasil (Goldblatt \& Henrich 1987). No Brasil, está indicada para as Regiões Norte, Nordeste, Centro-Oeste e Sudeste (Eggers et al. 2016). Na Bahia, ocorre principalmente na porção oeste do estado, em áreas de cerrado, com apenas uma coleta registrada na porção leste, no município de Entre Rios, em área de mata atlântica. D2, D9/10, F3, G4: cerrado, na porção oeste do estado, e mata atlântica, na porção leste; em altitudes entre 430 e $590 \mathrm{~m}$. Floresce e frutifica de janeiro a outubro. As flores se abrem pela manhã e se fecham por volta das 14:00 horas.

Material selecionado - Barreiras, Cachoeira do Redondo no Rio de Janeiro, cerca de $20 \mathrm{~km}$ em estrada de terra depois da

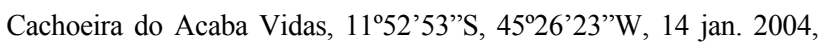
M. Machado \& M.V.M. Oliveira 124 (HUEFS); Correntina, rio Corrente, 21 jan. 1997, G. Hatschbach et al. 66036 (MBM); Entre Rios, Pau de Umbigo, próximo à entrada da fazenda Coité, $11^{\circ} 52^{\prime} \mathrm{S}$, $38^{\circ} 02^{\prime}$ W, 8 out. 2014, P.N. Oliveira et al. 120 (HUEFS); Formosa do Rio Preto, Arroz de Baixo, ca. $11 \mathrm{~km}$ da cidade, fazenda do Sr. Júlio,

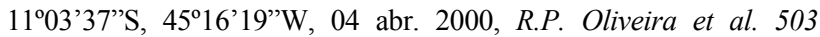
(CEPEC, HUEFS); Malhada, rodovia BR-030, próximo ao trevo para Iuiú, 30 out. 2004, G. Hatschbach \& E. Barbosa 78782 (MBM).

Cipura paludosa é a espécie-tipo do gênero (Aublet 1775). É facilmente reconhecida pela presença de bulbo com catafilos entremeados por resina, folhas linear-ensiformes plicadas, escapo com uma longa bráctea terminal foliácea e inflorescência congesta, 
com um a vários ripídios curto-pedunculados partindo da axila da bráctea. Geralmente ocorre em áreas alagadas, nas margens de lagos ou rios. Assemelha-se vegetativamente a Cipura xanthomelas, distinguindose principalmente pelas flores azuis (vs. flores amarelas), tépalas internas envolvendo completamente o gineceu e o androceu (vs. envolvendo parcialmente) e estiletes com ramos truncados (vs. com quatro lacínios agudos).

2.2. Cipura xanthomelas Maxim. ex Klatt., Abh. Naturf. Ges. Halle 15: 362. 1882.

Figuras 5E-H, 6 e 23F, G.

Nome popular: salsinha.

Ervas $15-70 \mathrm{~cm}$ alt.; bulbos $2,5-6 \times 2-5 \mathrm{~cm}$. Folhas 2-5 por planta, 4-70 $\times 0,5-2 \mathrm{~cm}$, linearensiformes, membranáceas. Escapo 8-55 cm compr., ápice portando uma bráctea foliácea, linear-ensiforme, de 10,5-24,5 × 0,6-1,5 cm. Ripídios $2-8$, sésseis a curto-pedunculados; pedúnculo até $0,5 \mathrm{~cm}$ compr.; espatas 2-6,2 × 0,8-1,3 cm. Flores amarelas; tépalas externas obovais a oblanceoladas, 1,5-3,6 × 0,3-1,4 $\mathrm{cm}$, patentes ou eretas, ápice arredondado a cuneado, região mediano-basal com margem reflexa; tépalas internas obovais, 0,6-1,5 × 0,2-1 cm, eretas, revolutas, escondendo parcialmente os estames e estiletes, ápice arredondado, máculas castanhas a negras na concavidade interna; filetes amarelos, 0,3-0,6 cm compr., anteras amarelas, 0,55-0,7 cm compr; ovário 0,5-1 $\times$ 0,1-0,3 cm, estiletes amarelos, 1,2-1,5 cm compr., unidos até 0,4-0,9 cm compr., ramos com quatro lacínios agudos, cristas estigmáticas triangulares, ápice agudo, as duas laterais $0,3-0,4 \mathrm{~cm}$ compr., as duas centrais ca. $0,1 \mathrm{~mm}$ compr. Cápsulas elipsoides a ovoides, 1,3-1,7 × 0,4-0,8 cm; sementes $0,13-0,15 \times$ ca. $0,1 \mathrm{~cm}$.

Cipura xanthomelas é endêmica do Brasil, citada para os estados da Bahia, Maranhão, Goiás, Mato Grosso, Mato Grosso do Sul e Minas Gerais (Eggers et al. 2016). D1, E9, F1, F6, G5: caatinga, campo rupestre e cerrado, entre 450-1700 de altitude. Floresce de janeiro a julho e frutifica de fevereiro a julho. As flores se abrem pela manhã e se fecham por volta das 14:00 horas.

Material selecionado - Abaíra, Campo de Ouro Fino, $13^{\circ} 15^{\prime} \mathrm{S}$, 4154'W, 6 fev. 1992, E.N. Lughadha et al. H51050 (CEPEC, HUEFS, MBM, SPF); Caetité, $14 \mathrm{~km}$ de Caetité em direção a Mamiaçu, estrada de terra à esquerda da principal, entre Araçá e Pau Ferro, 10 jan. 2008, A.L. Côrtes et al. 62 (HUEFS); Correntina, fazenda Jatobá, $13^{\circ} 14^{\prime}$ S, $46^{\circ} 04^{\prime}$ W, 4 mar. 1991, L.G. Viollati et al. 248 a (SPF); Formosa do Rio Preto, ca. $20 \mathrm{~km}$ da guarita da

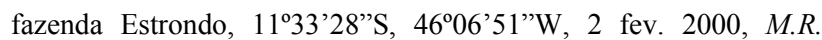
Fonseca et al. 1263 (CEPEC, HUEFS); Piatã, caminho para Três

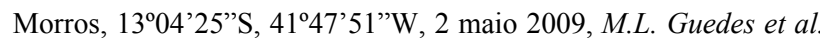
15133 (ALCB); Rio de Contas, fazenda Vacaro, 130.'03”'S, 41'29'13'W, 28 fev. 2002, A.M. Giulietti \& R.M. Harley 2065 (HUEFS); São Sebastião do Passé, área da Estação Experimental Sósthenes Miranda, Km 62 da BR-324, 16 jul. 1983 J.L. Hage et al. 1738 (CEPEC).
O hábito de Cipura xanthomelas assemelha-se ao de $C$. paludosa. No entanto, a cor da flor registrada nas etiquetas de herbários ou uma observação cuidadosa dos estiletes é suficiente para separá-las, pois $C$. xanthomelas apresenta os estiletes com quatro lacínios agudos muito característicos.

\section{Eleutherine Herb.}

Ervas com bulbo envolto por catafilos membranáceos, vermelhos a púrpura. Folhas espiraladas, planas, lineares a lanceoladas, plicadas. Escapo cilíndrico, simples ou ramificado, portando uma bráctea terminal, lanceolada, plicada. Ripídios axilares, laxos, pedunculados; espatas membranáceas a coriáceas. Flores brancas; tépalas subiguais, obovais, patentes, glabras; filetes livres, filiformes, glabros, anteras lineares, alternas aos estiletes; ovário oblongo, glabro, estiletes livres entre si, inteiros, reflexos, indivisos, estigmas apicais, globosos. Cápsulas cilíndricas, glabras; sementes elípticas.

Eleutherine é representado por apenas duas espécies, distribuídas na América Central e na América do Sul (Goldblatt et al. 2008). No Brasil, ocorre somente E. bulbosa (Eggers et al. 2016).

3.1. Eleutherine bulbosa (Mill) Urb., Repert. Spec. Nov. Regni Veg. 15: 305. 1918.

Figuras 5I-L, 6 e 23H, I.

Nome popular: ruibarbo.

Ervas 18-30 cm alt.; bulbos 1,5-4 × 1-2 cm. Folhas 1 ou 2 por planta, 9,5-17,5 × 6-7 cm, linearensiformes, membranáceas. Escapo 6-20 cm compr., ápice portando uma bráctea foliácea, linear-ensiforme, de 2,5-15 × 0,5-7 cm. Ripídios 3 ou 4, laxos; pedúnculo 1,3-4 cm compr.; espatas $1-1,5 \times 0,4-0,8$ $\mathrm{cm}$. Flores com tépalas obovais a oblanceoladas, 1-2,2 $\times 0,5-1 \mathrm{~cm}$, patentes, ápice arredondado, nervuras medianas evidentes, brancas a amarelas; filetes amarelos, 0,1-0,3 cm compr., anteras amarelas, ca. 0,4 $\mathrm{cm}$ compr.; ovário $0,2-0,3 \times$ ca. $0,15 \mathrm{~cm}$, estiletes amarelos, ca. 0,6 cm compr. Cápsulas não vistas.

Comum na região Neotropical, sendo associada ao cultivo humano para usos medicinais (Goldblatt \& Manning 2008). No Brasil, é citada para os estados do Acre, Paraíba, Distrito Federal, Goiás, Minas Gerais, Rio de Janeiro, São Paulo e Paraná (Eggers et al. 2016), sendo registrada pela primeira vez para a Bahia neste estudo. D/E9, I8: mata atlântica. Floresce de fevereiro a maio.

Material examinado - Entre Rios, Formoso, $12^{\circ} 01^{\prime} \mathrm{S}, 38^{\circ} 02^{\prime} \mathrm{W}$, 30 maio 2012, A.V. Popovkin \& J.C. Mendes 1122 (HUEFS); Santa Cruz Cabrália, Estação Ecológica do Pau-Brasil, cerca de 16 km W de Porto Seguro, rodovia BR-367 Porto Seguro-Eunápolis, 16²3'S, $39^{\circ} 08^{\prime} \mathrm{W}, 22$ fev. 1984, F.S. Santos 284 (CEPEC).

Eleutherine bulbosa é facilmente reconhecida por apresentar bulbo envolto por catafilos vermelhos a purpúreos, sendo a única espécie de Iridaceae da Bahia a apresentar essa característica. Também apresenta as 

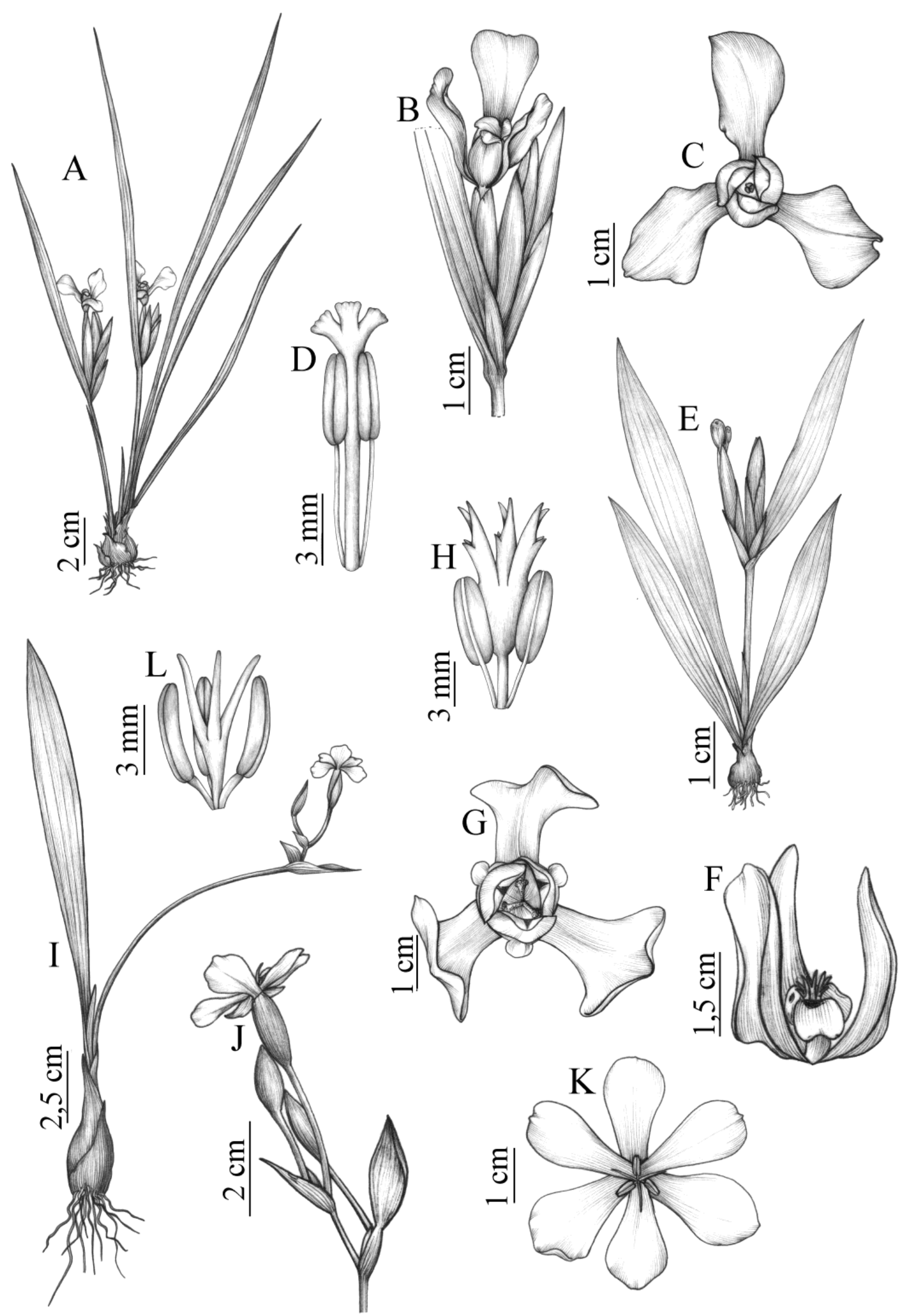

Figura 5. A-D. Cipura paludosa: A- hábito; B- inflorescência com flor, vista lateral; C- flor, vista frontal; D- estames e estiletes. E-H. C. xanthomelas: E- hábito; F- flor, vista lateral; G- flor, vista frontal; H- estames e estiletes. I-L. Eleutherine bulbosa: I- hábito; J- inflorescência; K- flor, vista frontal; L- estames e estiletes. (A, B- Oliveira 503 HUEFS; C, D- Popovkin 614 HUEFS; E- Lughadha H51050 CEPEC; F-H- Stannard H51774 HUEFS; I-L- Popovkin 1122 HUEFS). 


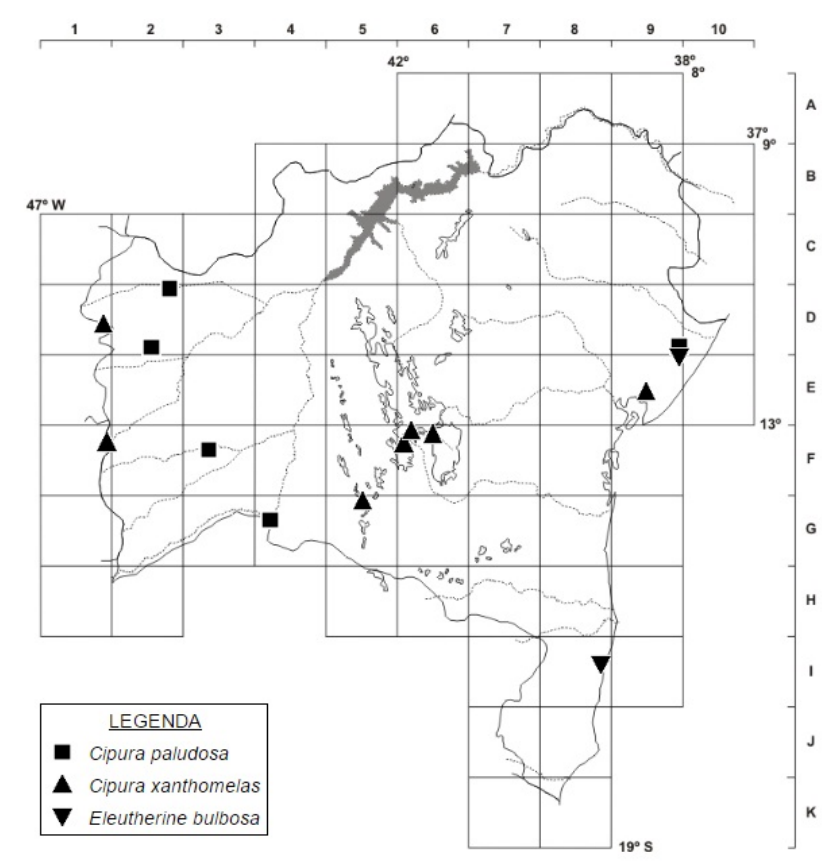

Figura 6. Mapa de distribuição de Cipura paludosa, C. xanthomelas e Eleutherine bulbosa no estado da Bahia.

folhas plicadas, uma única bráctea foliácea terminal no escapo, flores com tépalas subiguais, brancas, e estiletes cilíndricos, livres entre si.

\section{Neomarica Sprague}

Ervas com rizoma vertical ou horizontal. Folhas equitantes, planas, ensiformes a lanceoladas. Escapo achatado, alado, terminando em uma bráctea foliácea, linear-ensiforme. Ripídios axilares, laxos ou congestos, sésseis ou pedunculados, protegidos ou não por uma segunda bráctea, pedunculada ou séssil; espatas coriáceas. Flores brancas, amarelas ou roxas; tépalas desiguais, as externas maiores, obovais a oboval-elípticas, patentes, deflexas ou eretas, com estrias transversais na região basal; tépalas internas oboval-elípticas a oboval-oblongas, panduriformes, eretas, com ápice revoluto, concavidade interna mediana densamente pilosa, estrias transversais na região mediano-basal ou em toda a sua extensão; filetes livres, filiformes, de base dilatada, glabros, anteras lineares, opostas, adpressas aos estiletes; ovário oblongo, glabro, estiletes unidos na região mediano-basal, livres no ápice, ramos cuspidados, bífidos, trífidos ou multífidos, duas zonas estigmáticas transversais basais nas cristas. Cápsulas oboval-oblongas a cilíndricas, ápice truncado; sementes elípticas a ovais.

Neomarica compreende 24 espécies, que se distribuem no Brasil, do Piauí ao Rio Grande do Sul, com uma única espécie também nativa na Argentina, Paraguai e Uruguai (Gil et al. 2014). No Brasil, o maior centro de diversidade do gênero encontra-se na porção leste, particularmente na Região Sudeste e no sul da Bahia, onde estão amplamente distribuídas ao longo da costa brasileira, com algumas espécies em matas interioranas (Capellari Jr. 2000; Gil 2012). Na Bahia, ocorrem oito espécies, em subosques da mata atlântica, sendo cinco endêmicas.

\section{Chave para as espécies}

1. Folhas $0,5-1 \mathrm{~cm}$ larg.; tépalas internas com mácula apical castanha, triangular 4.2. N. castaneomaculata

1'. Folhas 2-6,5 cm larg.; tépalas internas sem mácula apical.

2. Pedúnculo da segunda bráctea 1,5 a $5,5 \mathrm{~cm}$ compr.; inflorescência laxa.

3. Ervas de $0,8-2 \mathrm{~m}$ alt.; segunda bráctea $8-15 \mathrm{~cm}$ compr.; frutos $6-8 \mathrm{~cm}$ compr.

3'. Ervas de 0,2-0,8 m alt.; segunda bráctea 2-6,5 cm compr.; fruto ca. $4 \mathrm{~cm}$ compr.

4.7. N. sabinei

4. Rizoma horizontal, totalmente subterrâneo; pedúnculo dos ripídios 5-6 cm compr.; estiletes brancos, ca. 2 cm compr.; anteras amarelas, 0,6-0,9 cm compr.

4.3. N. eburnea

4'. Rizoma vertical, com parte aérea longa; pedúnculo dos ripídios 1,5-3 cm compr.; estiletes roxos, 0,6-0,8 cm compr.; anteras brancas, 0,2-0,25 cm compr.

4.4. N. floscella

2 '. Pedúnculo da segunda bráctea até $0,5 \mathrm{~cm}$ compr.; inflorescência congesta.

5. Ripídio 1, inserido na segunda bráctea; tépalas externas eretas e côncavas, conferindo à flor um aspecto globoso; tépalas internas com margem involuta; estiletes $1-1,2 \mathrm{~cm}$ compr.

5'. Ripídios 1-6 (quando 1, nunca inserido na segunda bráctea); tépalas externas patentes (flor sem aspecto globoso); tépalas internas com margem não involuta; estiletes 1,5-2 cm compr.

6. Primeira bráctea 57-82 cm compr.; segunda bráctea com projeção alada conspícua, 11-14,3 cm compr.; flores bicromáticas (em tons de amarelo e castanho); tépalas externas com estrias castanhas longitudinais sinuosas na região mediana

4.1. N. brachypus

6'. Primeira bráctea 17-50 cm compr.; segunda bráctea com projeção alada inconspícua, 3-10 cm compr.; flores multicoloridas (em tons de amarelo, branco, castanho, azul e roxo); tépalas externas sem listras longitudinais na região mediana.

7. Ripídios 1-6; tépalas externas com região mediano-apical incurvada (subereta); tépalas internas com região mediano-apical tomentosa; estiletes com cristas de ápice longo-acuminado

7'. Ripídios 1 ou 2; tépalas externas com região mediano-apical patente ou recurvada; tépalas internas com região mediano-apical glabra; estiletes com cristas de ápice agudo .. 4.6. N. portosecurensis 
4.1. Neomarica brachypus (Baker) Sprague, Bull. Misc. Inform. Kew: 280. 1928.

Figuras 7A-D, 8 e 24A, B.

Ervas $0,5-0,9 \mathrm{~m}$ alt.; rizoma vertical subterrâneo, raramente com pequena porção aérea, $1,5-2 \mathrm{~cm}$ diâm. Folhas 5-7 por planta, 50-90 × 4-6 cm, largoensiformes. Escapo 8-20 $\times 1-1,5 \mathrm{~cm}$, mais curto que as folhas, deixando as flores comprimidas próximo à base da planta; primeira bráctea mais larga que o escapo, 57$82 \times 4,5-5 \mathrm{~cm}$, lanceolada. Ripídios 1-3, congestos; pedúnculo $0,7-1,5 \mathrm{~cm}$; segunda bráctea $11-14,3 \times 1-2,5$ $\mathrm{cm}$, ereta, folhosa, com projeção alada conspícua, séssil; espatas 3,5-5,5 $\times 1-2 \mathrm{~cm}$. Flores amarelas; tépalas externas elípticas a obovais, 4-4,5 × 1,5-2 cm, patentes, ápice arredondado a acuminado, estrias transversais castanhas na base, estrias longitudinais sinuosas castanhas na região mediana; tépalas internas obovaloblongas, 1,5-2 × 1-1,5 cm, ápice arredondado, região mediano-basal com estrias castanhas e tricomas capitados, duas máculas amarelo-intensas na concavidade interna; filetes amarelos, ca, $0,7 \mathrm{~cm}$ compr., anteras amarelas, ca. $0,7 \mathrm{~cm}$ compr.; ovário ca. $1,5 \mathrm{~cm}$ compr., estiletes amarelos, 1,8-2 cm compr., unidos até ca. $1,4 \mathrm{~cm}$ compr., ramos trífidos, cristas longotriangulares, ápice agudo, as laterais ca. $0,4 \mathrm{~cm}$, a central ca. $0,2 \mathrm{~cm}$. Cápsulas não vistas.

Endêmica do sul da Bahia (Gil 2012). G8, H8, K8: subosque de mata higrófila, em altitudes entre $450 \mathrm{e}$ $900 \mathrm{~m}$. Floresce de outubro a julho.

Material selecionado - Almadina, rodovia Almadina-Ibituã, entrada ca. $5 \mathrm{~km}$ da sede do município, fazenda Cruzeiro do Sul, Serra de Sete-paus, ca. $8 \mathrm{~km}$ da entrada $14^{\circ} 44^{\prime} 06^{\prime \prime}$ 'S, 3941'46"W, 15-16 jan. 1998, J.G. Jardim et al. 1241 (CEPEC, RB); Arataca, rodovia Arataca-Una, Serra do Peito de Moça, RPPN Palmeira/IESB, 15'10'27'S, 39²0'22'W, 17 dez. 2005, J.G. Jardim et al. 4827 (CEPEC); Barro Preto, Serra da Pedra Lascada, 13,7 km de Barro Preto, na estrada que passa pela fazenda São Miguel, 14\%46'13”S, 39¹2'10”'W, 23 jan. 2004, P. Fiaschi et al. 1912 (CEPEC); Jussari, RPPN Serra Teimoso, fazenda Teimoso, $1,7 \mathrm{~km}$ da entrada, 1509'16”'S, 39³1'52”'W, 13 fev. 2004, A.M. Amorim et al. 4479 (CEPEC); Mucuri, assentamento Paulo Freire, $2 \mathrm{~km}$ antes da sede do assentamento, $18^{\circ} 04^{\prime 2} 24^{\prime} \mathrm{S}, 39^{\circ} 40^{\prime} 24^{\prime \prime} \mathrm{W}, 4$ out. 2000, L.A. MattosSilva et al. 4139 (ALCB, CEPEC, HUEFS, HUESC).

Neomarica brachypus caracteriza-se pelas folhas largo-ensiformes e pela inflorescência congesta, com flores situadas próximo à base da planta, segunda bráctea folhosa e com projeção alada conspícua, e 1 a 3 ripídios congestos. As flores bicromáticas em tons de amarelo e castanho diferenciam-na de todas as outras espécies de Neomarica (Gil 2012). Vegetativamente, assemelha-se a $N$. portosecurensis e $N$. unca, devido às folhas largas, ultrapassando o escapo em comprimento, e pelos ripídios congestos. No entanto, a presença da segunda bráctea bem desenvolvida, com projeção alada conspícua, facilita sua distinção.

\subsection{Neomarica castaneomaculata A.Gil M.C.E.Amaral, Phytotaxa 286(2): 90. 2016.} Figuras 7E-I, 8, 24C, D.
Ervas $0,5-0,7 \mathrm{~cm}$ alt.; rizoma vertical subterrâneo, recurvado, $0,5-0,8 \mathrm{~cm}$ diâm. Folhas $5-8$ por planta, $36-45 \times 0,5-1 \mathrm{~cm}$, ensiformes. Escapo $38-50 \times 0,3-$ $0,5 \mathrm{~cm}$, ultrapassando as folhas em comprimento, projeção da nervura conspícua; primeira bráctea de largura igual ou maior que o escapo, 6,5-16 × 0,4-1 $\mathrm{cm}$, lanceolada. Ripídios 1 ou 2, laxos; pedúnculo $2-$ $2,5 \mathrm{~cm}$; segunda bráctea $2,4-3 \times 0,4-0,6 \mathrm{~cm}$, ereta ou patente, navicular, com projeção alada inconspícua e pedúnculo de 2-4 cm compr.; espatas $3-3,2 \times 0,5-0,8$ $\mathrm{cm}$. Flores brancas; tépalas externas elípticas, $2-2,5 \times$ $0,8-1 \mathrm{~cm}$, patentes, ápice arredondado, base amarelada com estrias castanhas; tépalas internas obovaloblongas, $1,5-1,8 \times$ ca. $0,5 \mathrm{~cm}$, ápice arredondado, região mediano-apical com margens amareladas e estrias castanhas, ápice com grande mácula castanha, triangular; filetes castanhos, ca. 0,4 cm compr., anteras verdes, ca. 0,4 cm compr.; ovário ca. 0,6 cm compr., estiletes amarelos, ca. 1,2 cm compr., unidos até ca. 0,8 $\mathrm{cm}$ compr., ramos trífidos, cristas longo-triangulares, ápice agudo, as laterais ca. $0,3 \mathrm{~cm}$, a central ca. $0,2 \mathrm{~cm}$. Cápsulas não vistas.

Ocorre nos estados da Bahia e Espírito Santo, em vales e encostas de mata atlântica ombrófila, sempre relacionada a margens de cursos d'água (Oliveira et al. 2016). E8: mata ciliar. Floresce em maio.

Material examinado - Elísio Medrado, Gambá, topo do afloramento, Morro dos Lírios, 1252'S, 39²8'W, 19 maio 2003, C. van den Berg 949 (parátipo HUEFS).

Material adicional - BRASIL. ESPÍRITO SANTO: Santa Tereza, Estação Biológica de Caixa D’água, 4 fev. 1986, B. Fernandes 1840 (isótipo ESA); estrada Santa Tereza-Alto do Santo Antônio, 22 abr. 1983, C. Farney et al. 299 (parátipo RB).

Neomarica castaneomaculata diferencia-se das demais espécies do gênero pelas flores com uma mácula castanha de aspecto triangular no ápice das tépalas internas. É facilmente reconhecida pelas folhas estreitas, com 0,5-1 cm de largura, escapo ultrapassando as folhas em comprimento, inflorescência laxa, tépalas externas com região mediano-apical branca e ausência de máculas amarelointensas na base do terço superior das tépalas internas.

\subsection{Neomarica eburnea A.Gil \& M.C.E.Amaral,} Phytotaxa 164(1): 48. 2014.

Figuras 8 e 24E, F.

Ervas $0,4-0,8 \mathrm{~m}$ alt.; rizoma horizontal subterrâneo, geralmente recurvado, $1,5-2 \mathrm{~cm}$ diâm. Folhas 4-6 por planta, 40-72 $\times 2-4 \mathrm{~cm}$, ensiformes. Escapo 47,5-80 × 1-1,8 cm, ultrapassando as folhas em comprimento, com projeção da nervura conspícua; primeira bráctea com a mesma largura do escapo, 2,5$23 \times 1-2,5 \mathrm{~cm}$, navicular. Ripídios 1-4, laxos; pedúnculo 5-6 cm; segunda bráctea 2,7-6,5 × 0,6-2 cm, ereta ou patente, navicular, com projeção alada pequena a média e pedúnculo de 3,8-5,5 cm compr.; espatas 4-6 $\& \times 1-1,6 \mathrm{~cm}$. Flores creme (cor de marfim); tépalas externas elípticas, 4-4,6 × 2-2,6 cm, patentes ou reflexas, ápice acuminado, base amarelada com estrias 


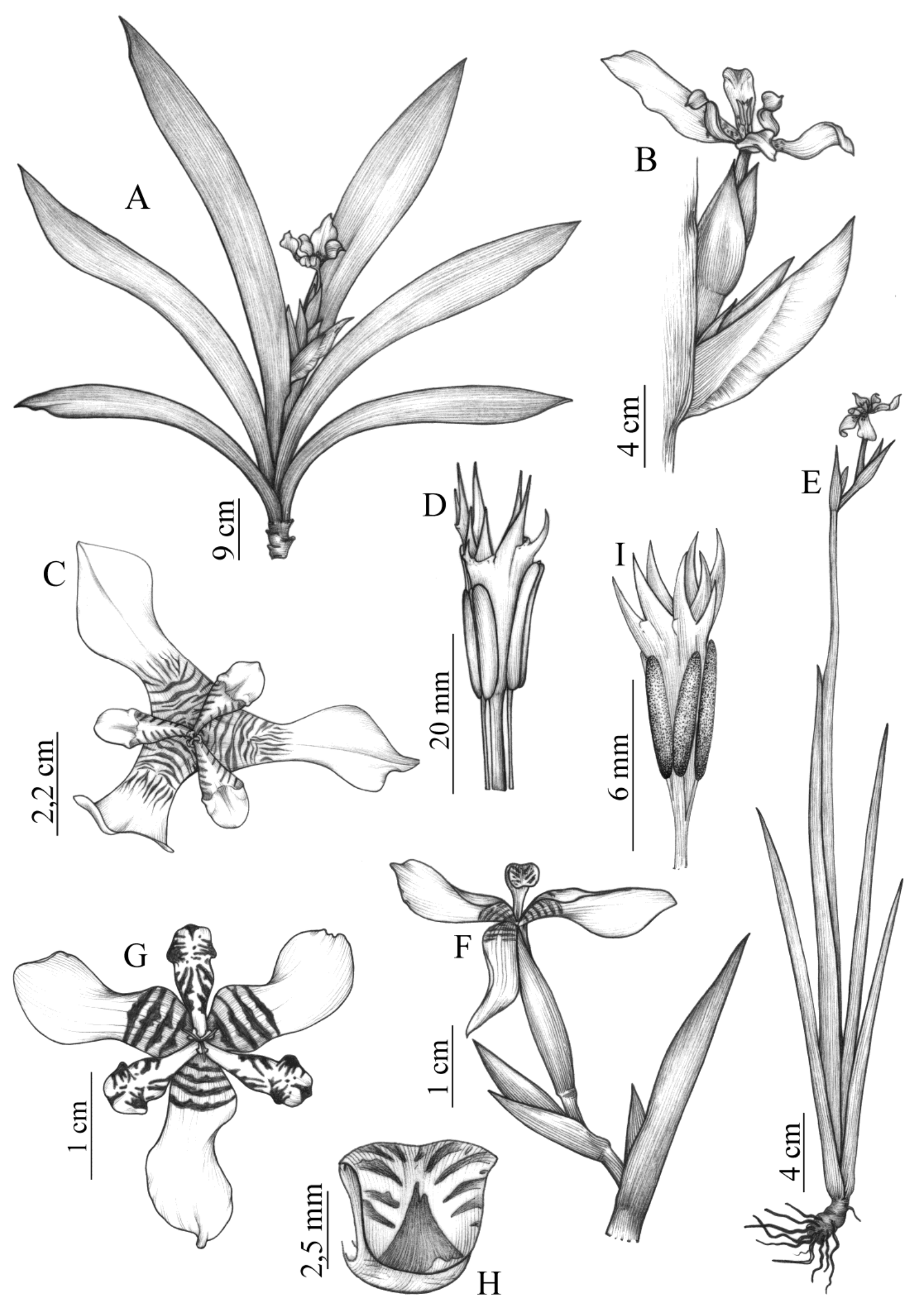

Figura 7. A-D. Neomarica brachypus: A- hábito; B- inflorescência; C- flor, vista frontal; D- estames e estiletes. E-I. Neomarica castaneomaculata: E- hábito; F- inflorescência; G- flor, vista frontal; H- tépala interna com grande mácula triangular no ápice; I- estames e estiletes. (A- Amorim 4479 CEPEC; B-D- Jardim 4488 CEPEC; E, F- van den Berg 949 HUEFS; G, I- Gil 148 UEC; H- Gil 168 UEC). 


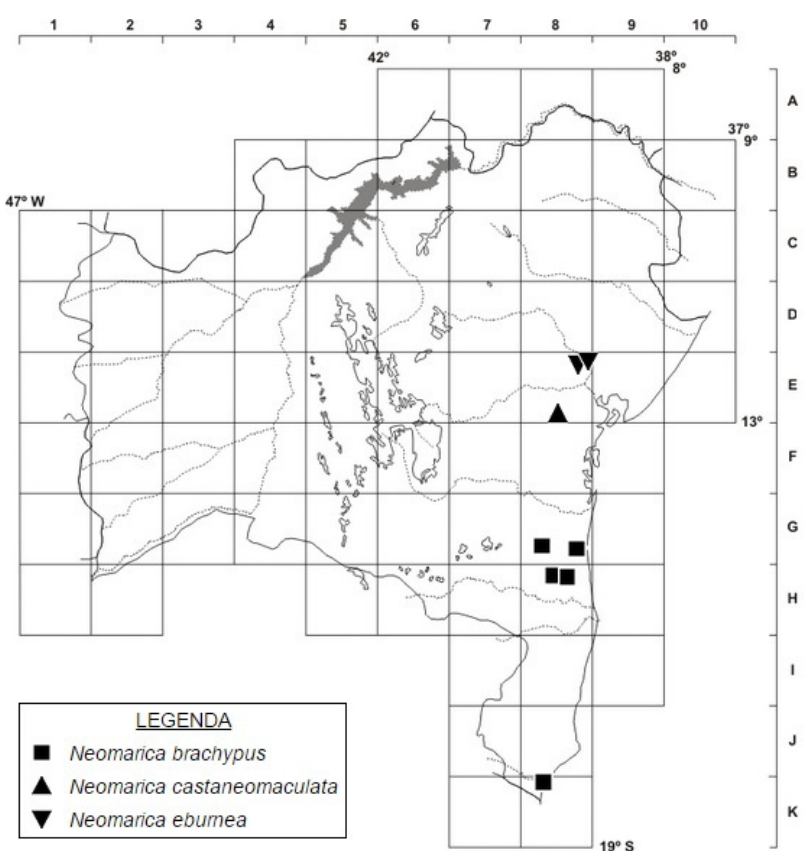

Figura 8. Mapa de distribuição de Neomarica brachypus, $N$. castaneomaculata e $N$. eburnea no estado da Bahia.

castanhas; tépalas internas oboval-oblongas, 2,8-3,2 $\times$ 1,1-1,2 cm, ápice arredondado, região mediano-apical com estrias roxas, margem branca, duas máculas amarelo-intensas na concavidade interna, região basal com estrias castanhas; filetes amarelos, 0,4-0,5 cm compr, anteras amarelas, 0,6-0,9 cm compr; ovário ca. $1,4 \mathrm{~cm}$ compr., estiletes brancos, ca. $2 \mathrm{~cm}$ compr, unidos até ca. 1,2 cm compr., ramos trífidos, cristas longo-triangulares, ápice acuminado, as laterais ca. 0,6 $\mathrm{cm}$, a central ca. $0,3 \mathrm{~cm}$. Cápsulas oboval-oblongas, ca. $4 \times 1,6 \mathrm{~cm}$.

Endêmica da Bahia (Gil et al. 2014). E8: subosque de remanescentes de floresta estacional seca, em altitudes entre 380 e $460 \mathrm{~m}$. Floresce de outubro a fevereiro. As flores se abrem e murcham no período da manhã, diferentemente das outras espécies de Neomarica, cujas flores murcham à tarde (Gil et al. 2014).

Material selecionado - Anguera, morro da fazenda Retiro, $12^{\circ} 10^{\prime} 01^{\prime \prime S}, 39^{\circ} 11^{\prime} 16^{\prime} \mathrm{W}, 21$ nov. 2006, D. Cardoso \& F. França 1426 (parátipo HUEFS); Feira de Santana, Distrito de Maria Quitéria, Pé de Serra, Serra de São José, $12^{\circ} 06^{\prime} 56^{\prime}$ 'S, 3902'56”W, 1 mar. 2005, A. Gil et al. 161 (holótipo UEC).

Neomarica eburnea caracteriza-se pelo escapo ultrapassando as folhas em comprimento, com projeção da nervura conspícua, inflorescência laxa, ripídios com pedúnculos de 5-6 $\mathrm{cm}$ de comprimento e segunda bráctea navicular, com pedúnculos conspícuos de 3,8$5,5 \mathrm{~cm}$ de comprimento. Pela morfologia floral, assemelha-se a $N$. portosecurensis, por apresentar flores predominantemente creme e cristas longotriangulares. No entanto, difere prontamente por apresentar a segunda bráctea conspicuamente pedunculada (vs. séssil a subséssil) e ripídios laxos (vs. congestos).
4.4. Neomarica floscella A.Gil \& M.C.E.Amaral, Phytotaxa 164(1): 51. 2014.

Figuras 10 e $25 \mathrm{~A}, \mathrm{~B}$.

Ervas $0,2-0,7 \mathrm{~m}$ alt.; rizomas verticais, ca. $1-5 \mathrm{~cm}$ acima do solo, 0,7-2 cm diâm. Folhas 6-9 por planta, 20-70 × 1,5-3 cm, ensiformes. Escapo 25-60 × 1-2 $\mathrm{cm}$, geralmente com o mesmo comprimento das folhas, projeção da nervura conspícua; primeira bráctea com a mesma largura do escapo, 7-22 × 1-2 cm, lanceolada. Ripídios 3-5, laxos; pedúnculo 1,5-3 cm; segunda bráctea $2-5,7 \times 0,5-0,8 \mathrm{~cm}$, ereta ou patente, navicular, com projeção alada conspícua e pedúnculo de 1,5-3 $\mathrm{cm}$ compr.; espatas 2,5-3,5 $\times 0,4-0,6 \mathrm{~cm}$. Flores brancas; tépalas externas elípticas a obovais, 2-2,1 $\times$ 0,9-1,1 cm, patentes ou reflexas, ápice obtuso a acuminado, base pilosa, amarelada com estrias castanhas; tépalas internas oboval-oblongas, 1,2-1,3 $\times$ 0,3-0,4 cm, ápice arredondado, pilosas em toda a extensão, região basal amarelada com estrias castanhas, região mediano-apical com estrias roxas ou azuis, duas máculas amarelo-intensas na concavidade interna; filetes castanhos a amarelos, 0,2-0,25 cm compr, anteras amarelas, 0,2-0,25 cm compr.; ovário 0,6-0,7 cm compr., estiletes $0,6-0,8 \mathrm{~cm}$ compr., roxoclaros, unidos até ca. 0,4-0,6 cm compr., ramos trífidos, cristas longo-triangulares, ápice agudo, as laterais e central de mesmo tamanho, ca. $1 \mathrm{~mm}$. Cápsulas cilíndricas, ca. $4 \times 1 \mathrm{~cm}$.

Endêmica do sul da Bahia (Gil et al. 2014). G8/9: em subosque de mata higrófila. Floresce e frutifica o ano todo.

Material selecionado - Itacaré, APA de Itacaré/Serra Grande, assentamento rural Camboinha, $\mathrm{Km} 12$ da rodovia Itacaré-Serra Grande, 14 fev. 2014, P.N. Oliveira et al. 116 (HUEFS); Uruçuca, Distrito de Serra Grande, 7,3 km na estrada Serra Grande-Itacaré, cerca de $7 \mathrm{~km}$ da entrada para Serra Grande-Itacaré, 14\%25'46”'S, 3903'12"W, 1 fev. 2006, A. Gil et al. 180 (holótipo UEC).

Neomarica floscella possui rizoma vertical com parte aérea longa, escapo geralmente com o mesmo comprimento das folhas, com projeção da nervura conspícua, inflorescência laxa, com três a cinco ripídios e pedúnculos de 1,5-3 cm de comprimento. Apresenta a menor flor dentre as espécies de Neomarica da Bahia, com 3-4 cm de diâmetro, sendo predominantemente branca.

\subsection{Neomarica involuta A.Gil \& M.C.E.Amaral,} Phytotaxa 286(2): 93. 2016.

Figuras 9A-D, 10 e 25C, D.

Ervas $0,2-0,4 \mathrm{~m}$ alt.; rizoma vertical ou horizontal subterrâneo, com extensão acima do solo, 0,7-1 cm diâm. Folhas 4-6 por planta, inseridas ao longo de um caule herbáceo aéreo, 24-40 × 2,5-3,5 cm, largo- a estreito-ensiformes. Escapo 10-17 × 1-2 cm, mais curto que as folhas, projeção da nervura conspícua; primeira bráctea com o dobro da largura do escapo, 12-35 × 2-4 cm, lanceolada. Ripídio 1, séssil, inserido na segunda bráctea; segunda bráctea $2-8 \times 0,4-1 \mathrm{~cm}$, ereta, sem ou com pequena projeção alada, séssil ou 
pedúnculo até $0,5 \mathrm{~cm}$ compr.; espatas $3-3,5 \times$ ca. 0,5 $\mathrm{cm}$. Flores amarelas; tépalas externas elípticas a obovais, 5-6 × 2-4 cm, eretas, côncavas, ápice obtuso, região basal com estrias castanhas e margem revoluta; tépalas internas oboval-oblongas, 3,5-4 × 1,5-2 cm, ápice arredondado, região apical branca, com margem roxa, conspicuamente involuta, conferindo aspecto tubular, duas máculas amarelo-intensas na concavidade interna, base com estrias castanhas; filetes amarelos, ca. 0,2 cm compr., anteras amarelas, ca. 0,6 cm compr.; ovário ca. $0,9 \mathrm{~mm}$ compr., estiletes amarelos, $1-1,2 \mathrm{~cm}$ compr., unidos até ca. 0,6 cm compr., ramos trífidos, cristas longo-triangulares, ápice agudo, as laterais ca. $0,4 \mathrm{~cm}$, a central ca. $0,2 \mathrm{~cm}$. Cápsulas cilíndricas, 2,4$4 \times 1-1,5 \mathrm{~cm}$.

Ocorre nos estados da Bahia, Espírito Santo e Minas Gerais, em interior de floresta atlântica (Oliveira et al. 2016). H8: floresta ombrófila densa montana, em altitudes entre 835 e $1000 \mathrm{~m}$. Floresce e frutifica de maio a dezembro.

Material selecionado - Camacã, RPPN Serra Bonita, acesso pela rodovia Jacareci, ca. $10,6 \mathrm{~km}$ de Camacã, 15²2'52'S, 39³4'11'W, 27 jul. 2005, A.M. Amorim et al. 4164 (parátipo CEPEC).

Material adicional - BRASIL. ESPÍRITO SANTO: Santa Maria de Jetibá, terreno do Berger, 4 mar. 2006, L. Kollmann \& M.S.V. Berger 8738 (isótipo UEC).

Neomarica involuta é facilmente reconhecida pelas folhas inseridas ao longo de um caule aéreo herbáceo e pelo ripídio único, séssil, inserido na segunda bráctea. Diferencia-se das demais espécies do gênero pelas flores amarelas, com tépalas eretas e côncavas, conferindo um aspecto globoso à flor. É a única espécie de Trimezieae com ápice das tépalas internas de margem involuta, em forma de tubo.

\subsection{Neomarica portosecurensis (Ravenna) Chukr, Novon 11(4): 379. 2001.}

Figuras 9E-H, 10 e 25E, F.

Ervas $0,5-0,85 \mathrm{~m}$ alt.; rizomas verticais subterrâneos, por vezes com porção aérea, $1-2 \mathrm{~cm}$ diâm. Folhas 4-6 por planta, 45-63 × 2-4 cm, largo- a estreito-ensiformes. Escapo 10-37 × 1-2,5 cm, mais curto que as folhas; primeira bráctea com cerca do dobro da largura do escapo, 17-38 $\times 2-5 \mathrm{~cm}$, lanceolada. Ripídios 1 ou 2, congestos; pedúnculo até $1 \mathrm{~cm}$; segunda bráctea $3-8 \times 0,7-1,5 \mathrm{~cm}$, ereta, com projeção alada média, séssil a curto-pedunculada; espatas 4-5 × 1-1,5 cm. Flores creme; tépalas externas elípticas, 2,5-3 × 1-1,5 cm, patentes, ápice cuspidado, base amarelada com estrias transversais castanhas, margens amareladas; tépalas internas oboval-oblongas, $1-1,5 \times 0,5-1 \mathrm{~cm}$, ápice obtuso, glabro, região mediano-basal com estrias castanhas, glabras, duas máculas amarelo-intensas na concavidade interna, estrias azuis a roxas no ápice; filetes amarelos, $0,4-0,5$ cm compr., anteras brancas, $0,4-0,5 \mathrm{~cm}$ compr.; ovário $0,8-1 \mathrm{~cm}$ compr., estiletes ca. $1,5 \mathrm{~cm}$ compr., brancos com região basal amarelada, unidos até ca. $1 \mathrm{~cm}$ compr., ramos trífidos, cristas longo-triangulares, ápice agudo, as laterais ca. $0,5 \mathrm{~cm}$, a central ca. $0,3 \mathrm{~cm}$. Cápsulas oboval-oblongas, $5-7 \times 1-2 \mathrm{~cm}$.

Endêmica da Bahia (Chukr \& Giulietti 2001; Gil 2012), ocorrendo principalmente no sul do estado. E8, E9/10, G8, I8, J8: interior de floresta ombrófila antropizada, em floresta de tabuleiro, com altitudes entre 50 e $170 \mathrm{~m}$. Floresce de agosto a fevereiro e frutifica de setembro a março.

Material selecionado - Esplanada, Algodão, $12^{\circ} 10^{\prime} \mathrm{S}$, $37^{\circ} 58^{\prime} \mathrm{W}, 2$ out. 2013, A.V. Popovkin \& J.C. Mendes 1551 (HUEFS); Eunápolis, saída de Eunápolis a Itamaraju, BR-101, 40 $\mathrm{km}$ de Itamaraju, 16 set. 1968, J. Almeida \& T.S. Santos 34 (CEPEC, RB); Ilhéus, rodovia Ilhéus-Itacaré, BA-001, na altura do $\mathrm{Km} 20$, estrada à esquerda, para a Lagoa Encantada, 14³5'10"S, $39^{\circ} 07^{\prime} 02^{\prime \prime} \mathrm{W}, 13$ fev. 2014, P.N. Oliveira et al. 114 (HUEFS); Porto Seguro, RPPN Estação Veracel, 16 $30^{\circ}$ 'S, $39^{\circ} 15^{\prime} \mathrm{W}, 27$ ago. 2012, G.M. Carvalho et al. 401 (CEPEC); Prado, Parque Nacional do Descobrimento, entrada à esquerda no $\mathrm{Km} 8$ da estrada principal que atravessa o Parque, $17^{\circ} 11^{\prime} \mathrm{S}, 39^{\circ} 20^{\prime} \mathrm{W}, 3$ nov. 2011, L. Daneu et al. 217 (CEPEC); Santa Cruz Cabrália, Reserva Biológica de PauBrasil, 17 set. 1971, T.S. Santos 1954 (isótipo CEPEC); Santa Teresinha, Serra da Jiboia, no caminho para as antenas no topo da serra, 27 fev. 2005, A. Gil \& L.Y.S. Aona 156 (UEC).

Neomarica portosecurensis assemelha-se vegetativamente a $N$. brachypus e $N$. unca, pelas folhas largas que ultrapassam o escapo em comprimento e pela inflorescência congesta, com a segunda bráctea séssil a curto-pedunculada. Distingue-se de $N$. brachypus por ter a segunda bráctea com projeção alada inconspícua (vs. conspícua), flores multicoloridas (vs. bicromáticas, em tons de amarelo e castanho) e tépalas externas sem listras longitudinais na região mediana (vs. com estrias longitudinais sinuosas), e de $N$. unca pelo número de ripídios, geralmente maior (até 6 vs. até 2), e tépalas externas com ápice patente ou recurvado (vs. incurvado).

\subsection{Neomarica sabinei (Lindl.) Chukr, Novon 11(4):} 379. 2001 (como "sabini").

Figuras 11A-E, 12 e 26A, B.

Ervas 0,8 a 2 m alt.; rizoma vertical ou horizontal, subterrâneo, 2-3 cm diâm. Folhas 5-10 por planta, 43$100 \times 2-5 \mathrm{~cm}$, ensiformes. Escapo 40-130 × 1,5-3 cm, geralmente ultrapassando as folhas em comprimento; primeira bráctea semelhante ao ápice das folhas, mesma largura do escapo, 15-54 × 1,5-3,5 cm, lanceolada. Ripídios 1-4, laxos, sendo 1 séssil na axila do pedúnculo da segunda bráctea $\mathrm{e}$ os outros emergindo desta, com pedúnculos de 1,5-3 cm compr.; segunda bráctea $8-15 \times 1-2,2 \mathrm{~cm}$, patente, navicular, com projeção alada média e pedúnculo de $1,5-4 \mathrm{~cm}$ compr.; espatas 6-8 × 0,6-2,5 cm. Flores brancas, azuis ou roxas; tépalas externas elípticas ou largo-elípticas, 4-6 $\times 2-4 \mathrm{~cm}$, patentes ou reflexas, ápice acuminado, base amarelada com estrias castanhas e tricomas capitados; tépalas internas oboval-elípticas, 2,5-4,5 × $1,3-2,5 \mathrm{~cm}$, tricomas capitados em toda a extensão, ápice obtuso, região basal amarelada com estrias 


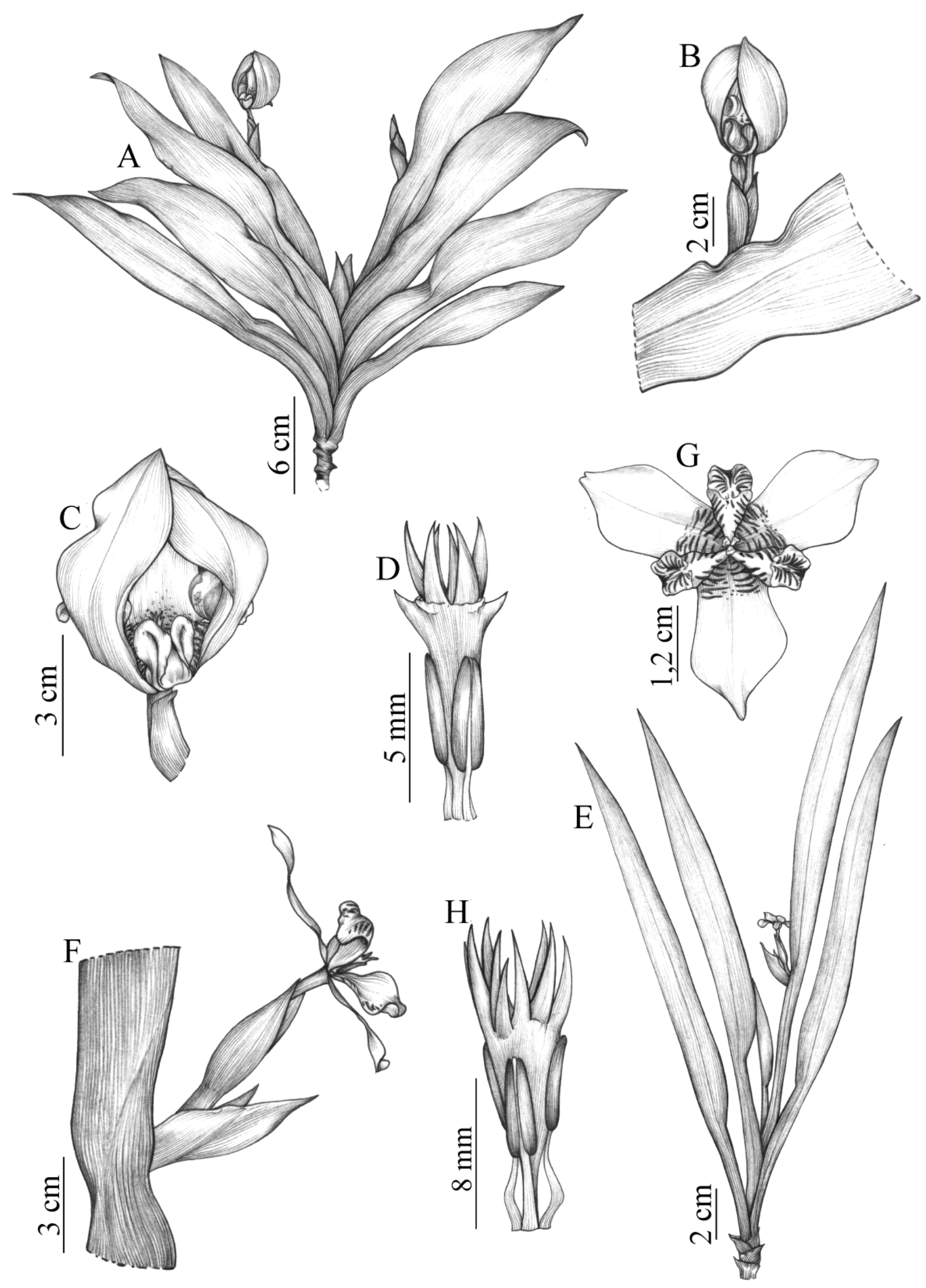

Figura 9. A-D. Neomarica involuta: A- hábito; B- inflorescência; C- flor, vista lateral; D- estames e estiletes. E-H. N. portosecurensis: E- hábito; F- Inflorescência; G- flor, vista frontal; H- estames e estiletes. (A, B- Perdiz 284 UEC; C, D- Kollmann 8738 UEC; E, FCarvalho 401 CEPEC; G, H- Gil 156 UEC). 


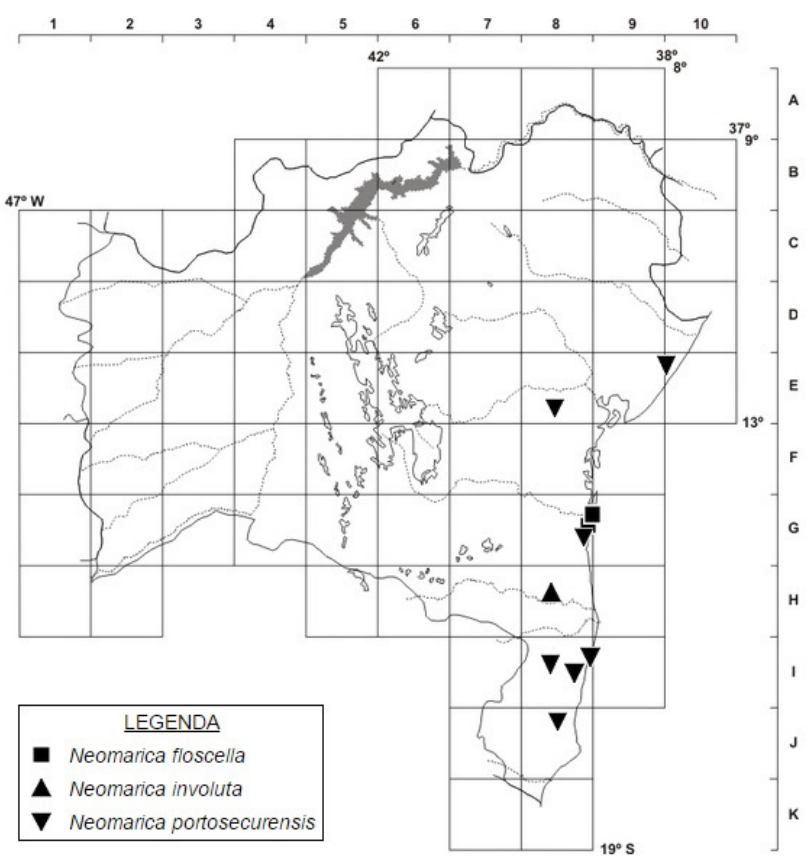

Figura 10. Mapa de distribuição de Neomarica floscella, $N$. involuta e $N$. portosecurensis no estado da Bahia.

castanhas, região mediano-apical com estrias roxas ou azuis, duas máculas amarelo-intensas na concavidade interna; filetes castanhos a amarelos, 0,4-0,7 cm compr., anteras amarelas, 0,8-1,5 cm compr.; ovário $1-1,3 \mathrm{~cm}$ compr., estiletes 2-2,3 cm compr., amarelados com lacínios brancos ou arroxeados, unidos até ca. 1,3 cm compr., ramos trífidos, cristas curto-triangulares, ápice agudo, as laterais ca. $0,5 \mathrm{~cm}$, a central ca. $0,25 \mathrm{~cm}$. Cápsulas obovoides, $6-8 \times 1,2-2$ $\mathrm{cm}$.

Ocorre na Bahia e no Espírito Santo, principalmente em matas de encosta e restinga (Gil 2012); amplamente utilizada em paisagismo, também pode ser encontrada em outros estados brasileiros. D10, E8, E9, F7, F8, G8, G8/9, H9, I8, I8/9, J8: caatinga, capoeira, mata de restinga, mata ombrófila densa, em altitudes até $800 \mathrm{~m}$. Floresce de janeiro a agosto e frutifica de fevereiro a setembro.

Material selecionado - Almadina, 12 mar. 1971, S.P. Raimundo 1125 (CEPEC); Belmonte, Km 20 a 21 da rodovia Belmonte-Itapebi, 26 jul. 1988, T.S. Santos et al. 4386 (CEPEC); Buerarema, aldeia dos índios Tupinambás da Serra do Padeiro, 14 ${ }^{\circ} 57^{\prime}$ S, 39 $9^{\circ} 17^{\prime} \mathrm{W}, 27$ maio 2007, G.S. Campos \& A.P. Alencar 65 (ALCB); Camaçari, Arembepe, Lagoa da Capivara, 17 ago. 2005, E.P. Queiroz \& F.S. Araújo 1141 (RB); Caravelas, MassanganoMacaco, 1740'21'S, 39¹5'35'W, 23 ago. 2011, E.N. Matos 402

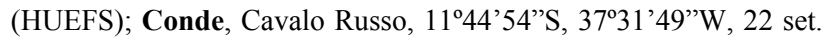
2002, N.G. Jesus 1482 (HUEFS); Elísio Medrado, Gambá, Morro dos Lírios, $12^{\circ} 52^{\prime} \mathrm{S}, 39^{\circ} 28^{\prime} \mathrm{W}, 19$ maio 2003, H. Vageler 948 (HUEFS); Igrapiúna, Pedra Branca, Casa de Edete Carolina Souza Santos, 21 jul. 2010, M.L. Guedes et al. 17473 (ALCB); Ilhéus, rodovia em direção a Una, em frente ao arraial Canabrava, 1459'39"S, 3859'59”'W, 13 fev. 2014, P.N. Oliveira et al. 113 (HUEFS); Itacaré, litoral sul, Fazenda das Bromélias, $14^{\circ} 16^{\prime} \mathrm{S}$, 3859'W, 17 mar. 2006, J.S. Santana et al. 42 (ALCB); Jequié, Km
7 da estrada Jequié-Ipiaú, 10 fev. 1983, A.M. Carvalho \& T. Plowman 1601 (CEPEC); Nova Viçosa, Km 5 da rodovia de Nova Viçosa para o Posto da Mata, 24 abr. 1973, R.S. Pinheiro 2107 (CEPEC); Olivença, Canabrava, 3-5 km W, 14 jun. 2003, G. Hatschbach et al. 75337 (MBM); Porto Seguro, ca. $8 \mathrm{~km} \mathrm{~N} \mathrm{de}$ Porto Seguro, 16²3'S, 3902'W, 21 mar. 1974, R.M. Harley 17283 (CEPEC, RB); Prado, 21 jan. 1974, T.S. Santos 2731 (CEPEC); Presidente Tancredo Neves, Riachão dos Caboclos, Casa de Maria dos Montes Merces Santos, 1322'37'’S, 39²0'52'W, 20 jul. 2010, M.L. Guedes et al. 17434 (ALCB); Santa Cruz Cabrália, Estação Ecológica do Pau-Brasil, ESPAB, ca. $16 \mathrm{~km} \mathrm{~W}$ de Porto Seguro, BR-367, Porto Seguro-Eunápolis, $16^{\circ} 23^{\prime}$ 'S, 3908'W, 22 fev. 1984, F.S. Santos 268 (CEPEC); Santa Terezinha, Serra da Jiboia, ca. 4 km após Pedra Branca, 1251'01'’S, 39²8'32'W, 2 mar. 2001, L.P. Queiroz et al. 6460 (HUEFS, UEC); Santo Antônio, estrada para Belmonte, 16 $06^{\circ} 22^{\prime \prime}$, 38 38 $57^{\prime} 43^{\prime} \mathrm{W}, 27$ dez. 2005, T.S. Nunes et al. 1412 (HUEFS).

Neomarica sabinei é amplamente cultivada no Brasil e foi introduzida em outros continentes, como África, Europa e Ásia, como também no norte do continente americano (Churkr \& Capellari Jr. 2003). A espécie é comum na Bahia e facilmente diferenciada das demais espécies do gênero pelo grande porte, com alturas variando de 0,8 a $2 \mathrm{~m}$, além do arranjo de sua inflorescência, na forma de um ripídio axilar à segunda bráctea e dois a três ripídios emergindo desta a partir de curtos pedúnculos. A espécie apresenta grande plasticidade fenotípica, principalmente em relação às flores, que podem variar de cor, do branco até o roxo ou azul, e ainda com grande variação do tamanho e forma dos verticilos florais.

Ao publicar o nome Marica sabini, Lindley (1826) prestou uma homenagem ao Capitão Edward Sabine, explorador inglês da América do Sul e África, tendo seu epíteto específico sido corrigido para "sabinei" (Gil 2012).

\subsection{Neomarica unca (Ravenna) A.Gil, Harvard Pap.} Bot. 14(2): 99. 2009.

Figuras 11D-I, 12 e 26C, D.

Ervas 0,4 a 0,7 m alt.; rizoma vertical subterrâneo, por vezes com porção aérea, $1-1,5 \mathrm{~cm}$ diâm. Folhas $6-$ 11 por planta, inseridas no mesmo ponto do rizoma, 35-70 × 4-6,5 cm, largo-ensiformes. Escapo 11-25 $\times$ $1,2-2,5 \mathrm{~cm}$, mais curto que as folhas; primeira bráctea com cerca do dobro da largura do escapo, 18-50 × 3,5$5 \mathrm{~cm}$, lanceolada. Ripídios 1-6, congestos; pedúnculo 0,5-1 cm compr.; segunda bráctea 5-10 × 1,2-1,5 cm, ereta ou patente, com projeção alada média, séssil ou com pedúnculo de ca. 0,5 cm compr.; espatas 4-5,6 $\times$ 0,6-1 cm. Flores amarelas; tépalas externas elípticas, 2,5-3,7 × 1-1,2 cm, patentes, ápice agudo, incurvado, margem amarelada, base com estrias transversais castanhas; tépalas internas oboval-oblongas, 1,5-2,5 $\times$ 0,6-0,8 cm, estrias transversais castanhas em toda a extensão, ápice obtuso, região mediano-apical densamente tomentosa, com estrias longitudinais roxas no centro, duas máculas amarelo-intensas na concavidade interna; filetes amarelos, $0,4-0,5 \mathrm{~cm}$ 


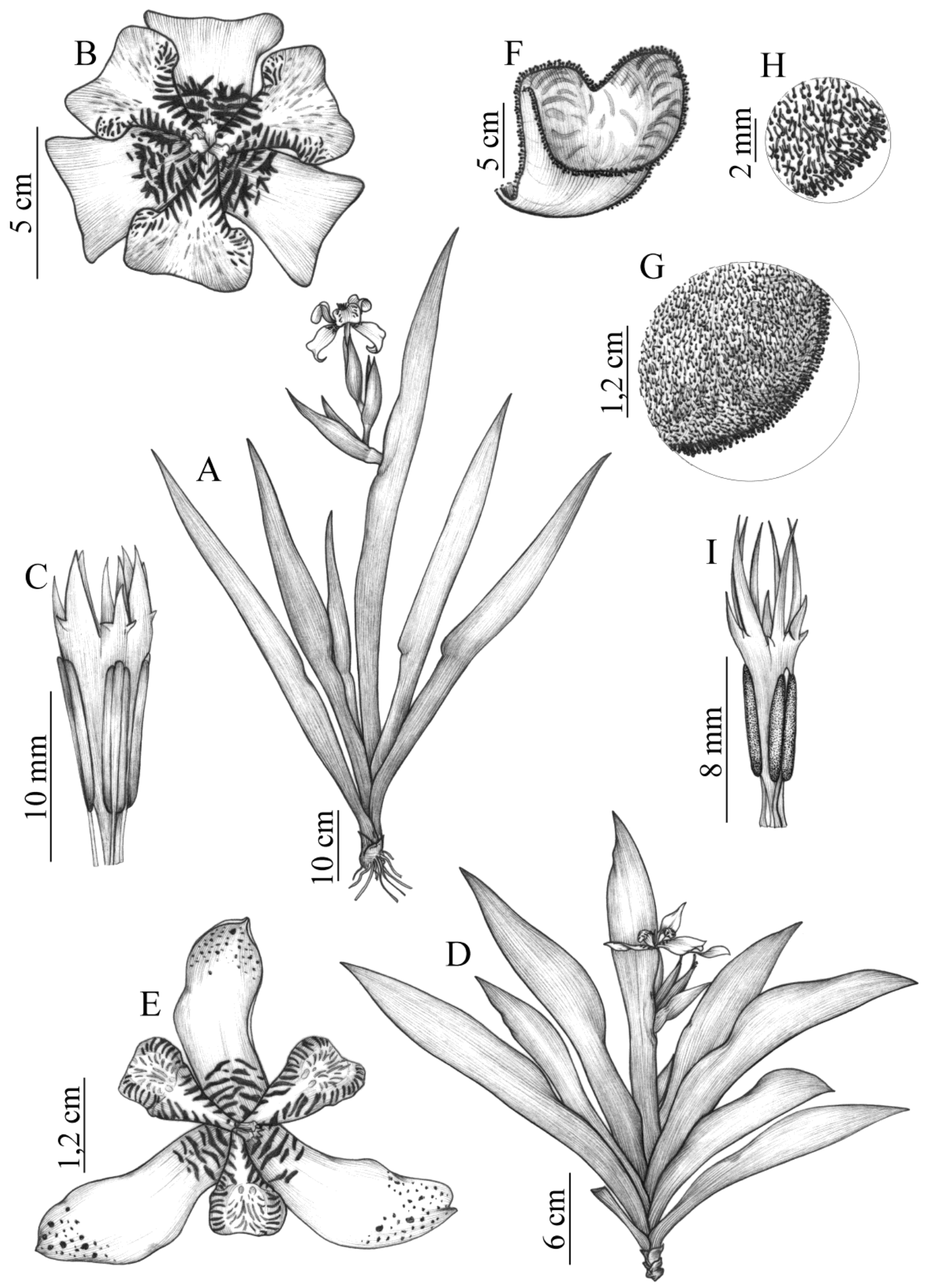

Figura 11. A-E. Neomarica sabinei: A- hábito; B- flor, vista frontal; C- estames e estiletes. D-I. N. unca: D- hábito; E- flor, vista frontal; F- tépala interna; G, H- detalhe do ápice da tépala interna densamente tomentoso; I- estames e estiletes. (A- Carvalho 1601 CEPEC; B, C- Oliveira 113 HUEFS; D- Jardim 4030 HUEFS; E- Jardim 4030; F-I- Gil 151 UEC). 
estiletes 1,6-2 cm compr., amarelos, unidos até 0,8-1 $\mathrm{cm}$ compr., ramos trífidos, cristas de ápice longoacuminado, as laterais $0,6-0,8 \mathrm{~cm}$, a central $0,3-0,4$ $\mathrm{cm}$. Cápsulas não observadas.

Endêmica de uma pequena região no sul da Bahia (Gil et al. 2009). H7, J8: floresta ombrófila densa, em altitudes entre 100 e $200 \mathrm{~m}$. Floresce de outubro a fevereiro.

Material selecionado - Itamaraju, fazenda Pau-Brasil, nov. 1990, P. Ravenna 3349 (holótipo MBM); Porto Seguro, Parque Nacional Monte Pascoal, trilha para o pico do Monte Pascoal, no início da trilha, com declividade baixa, 15¹5'53's, 40³4'29'W, 14 nov. 1996, W.W. Thomas et al. 11230 (CEPEC); Prado, rodovia para Cumuruxatiba, ca. 23 km, fazenda Conjunto Santo Antônio, 1700'18'S, 39¹5'06'W, 30 out. 2002, J.G. Jardim et al. 4030 (CEPEC, HUEFS).

Neomarica unca assemelha-se a $N$. brachypus e $N$. portosecurensis; diferenciando-se de N. brachypus por possuir a segunda bráctea com projeção alada inconspícua e flores multicoloridas e de $N$. portosecurensis por ter de 1 a 6 ripídios, tépalas externas com ápice incurvado e internas com região mediano-apical tomentosa.

\section{Pseudiris Chukr \& A.Gil.}

Ervas com cormo envolto por catafilos fibrosos, castanhos. Folhas espiraladas, planas, linear-ensiformes a ensiformes, subcoriáceas. Escapo cilíndrico, simples ou ramificado, portando brácteas naviculares em sua extensão. Ripídios terminais, laxos, pedunculados; espatas subcoriáceas. Flores lilás a azuis; tépalas desiguais, obovais a elípticas, patentes a reflexas, com tricomas capitados; filetes brancos, livres, filiformes, glabros, anteras azuis, lineares, adpressas aos ramos do estilete; ovário oblongo, glabro, estiletes roxos, unidos na região mediano-basal, livres no ápice, divergindo acima das anteras, ramos divididos em duas cristas petaloides, duas zonas estigmáticas transversais basais nas cristas. Cápsulas oboval-oblongas a oblongas, glabras; sementes angulares.

Pseudiris foi descrito para os campos rupestres do estado da Bahia, sendo representado por apenas uma espécie, $P$. speciosa (Gil et al. 2008).

\subsection{Pseudiris speciosa Chukr \& A.Gil, Proc. Calif.} Acad. Sci., ser. 4, 59(19): 725. 2008.

Figuras 1E, 2E, 12 e 26E, F.

Nome popular: lírio.

Ervas $40-170 \mathrm{~cm}$ alt.; cormos $2,5-5 \times 2,5-4 \mathrm{~cm}$.

Folhas 1-3 por planta, 30-129 × 0,7-2,2 cm. Escapo 49-147 cm compr., portando 3 ou 4 brácteas de 6,5-44 $\times 0,4-1,6 \mathrm{~cm}$, separadas por entrenós de $7-40 \mathrm{~cm}$ compr. Ripídios 1-3; pedúnculo 4,5-19 cm compr.; espatas 6-9 × 0,4-1,6 cm. Flores com tépalas externas maiores, obovais a oblongas, 3,5-6 × 1-2,4 cm, ápice emarginado, base com tricomas capitados; tépalas internas obovais a elípticas, $2-3,5 \times 0,8-1 \mathrm{~cm}$, ápice acuminado, região mediano-basal com estrias longitudinais roxas e listra mediana longitudinal linear,

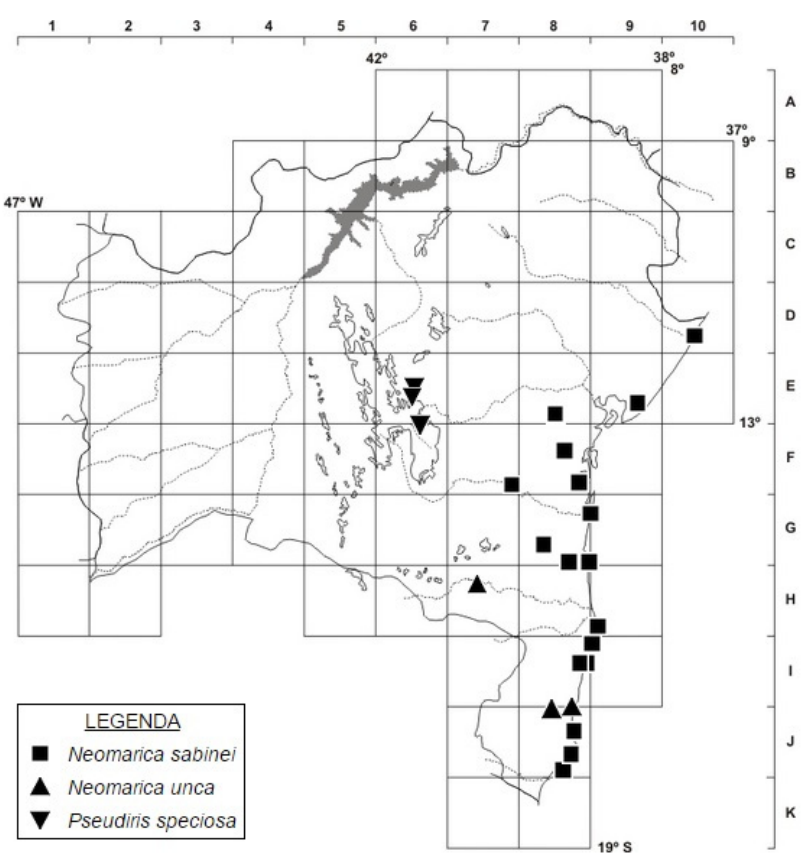

Figura 12. Mapa de distribuição de Neomarica sabinei, $N$. unca e Pseudiris speciosa no estado da Bahia.

amarela, com tricomas capitados; filetes 1,2-2 cm, anteras 1-1,3 cm compr.; ovário 0,8-1 cm compr., estiletes 3,2-3,7 cm compr., cristas petaloides, 1-1,2 $\mathrm{cm}$ compr., triangulares, ápice arredondado a truncado, eretas. Cápsulas 2,5-4 × 1-1,5 cm.

Restrita a uma porção da Chapada Diamantina (Gil et al. 2008), em altitudes entre 910 e $1500 \mathrm{~m}$. E6, E/F6: campo rupestre. Floresce e frutifica de janeiro a outubro.

Material selecionado - Lençóis, Serra da Chapadinha,

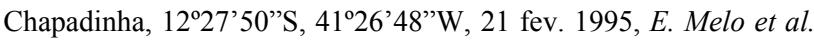
1660 (parátipo ALCB, CEPEC, SPF); Mucugê, Projeto Sempre Viva, 26 fev. 2001, A.A. Ribeiro-Filho 214 (holótipo HUEFS, isótipo UEC); Palmeiras, Parque Nacional Chapada Diamantina, Serra da Fumaça, 12³6'22'S, 41²8'59”'W, 27 out. 2012, G. Almeida-Silva \& M.F.M. Barros 307 (HUEFS).

Pseudiris speciosa se caracteriza por possuir caule subterrâneo do tipo cormo, envolto por catafilos fibrosos, folhas planas, subcoriáceas, escapo cilíndrico, com três ou quatro brácteas separadas por entrenós longos, flores lilás a azuis, tépalas desiguais e ramos do estilete com duas cristas petaloides amplas. A ornamentação de suas tépalas é bastante singular, devido às listras longitudinais medianas amarelas nas tépalas externas.

\section{Sisyrinchium L.}

Ervas com rizomas. Folhas equitantes, planas ou cilíndricas, lineares a lanceoladas, não plicadas. Escapos planos ou cilíndricos, simples ou ramificados, áfilos ou com uma a várias brácteas em sua extensão. Ripídios terminais ou axilares, laxos ou congestos, pedunculados ou sésseis; espatas membranáceas a crassas. Flores brancas, amarelas, róseas, azuis ou roxas, 
tépalas subiguais, ovais, oval-oblongas ou lanceoladas, patentes ou eretas, glabras ou não; filetes livres ou formando tubo estaminal, glabros ou pilosos, anteras oblongas, lineares ou sagitadas, alternas aos estiletes, muitas vezes recurvadas e retorcidas na maturidade; ovário globoso a subgloboso, glabro ou piloso, estiletes cilíndricos, unidos apenas na base ou em quase toda a sua extensão, livres no ápice, divergentes entre si, indivisos, estigmas apicais, globosos. Cápsulas globosas a obovoides, glabras ou pilosas.

Sisyrinchium possui cerca de 140 espécies, distribuídas no continente americano, incluindo uma espécie na Groelândia (Goldblatt et al. 2008). É o maior gênero de Iridaceae no Novo Mundo, especialmente em regiões de clima temperado ou subtropical, ou em altitudes elevadas (Chukr \& Capellari Jr. 2003; Goldblatt et al. 2008). Para o Brasil, são indicadas 67 espécies (Eggers et al. 2016) e, na Bahia, está representado por quatro espécies restritas à Chapada Diamantina.

\section{Chave para as espécies}

1. Folhas basais ausentes; diversas brácteas alternas ao longo do escapo 6.4. S. vaginatum

1'. Folhas basais presentes; uma ou duas brácteas no ápice do escapo.

2. Folhas e escapo cilíndricos

6.2. S. luzula

2'. Folhas e escapo planos.

3. Folhas 0,1-0,2 cm larg.; escapo portando apenas uma bráctea no ápice; filetes pilosos, anteras oblongas

6.1. S. commutatum

3'. Folhas 0,4-0,6 cm larg.; escapo portando duas brácteas alternas no ápice; filetes glabros, anteras sagitadas ... 6.3. S. nidulare

6.1. Sisyrinchium commutatum Klatt, Hamburger Garten- Blumenzeitung 16: 164. 1860.

Figuras $13 \mathrm{~A}-\mathrm{C}$, 14 e 27A, B.

Ervas 13 a $22 \mathrm{~cm}$ alt. Folhas $3-8$ por planta, 5-16 $\times 0,1-0,2 \mathrm{~cm}$, planas, cartáceas, margem delgada. Escapo 9,5-16,5 cm compr., plano, ápice portando uma bráctea terminal, plana, de $2-5 \times 0,1-0,2 \mathrm{~cm}$. Ripídios 1-3, congestos; pedúnculo 0,1-4 cm compr.; espatas $0,6-0,8 \times 0,3-0,4 \mathrm{~cm}$. Flores amarelas; tépalas oboval-oblongas, $0,25-0,5 \times 0,2-0,5 \mathrm{~cm}$, patentes, nervuras medianas evidentes, castanho-vináceas, ápice mucronado; filetes amarelos, 0,15-0,2 cm compr., unidos até $0,1-0,15 \mathrm{~cm}$ compr., formando tubo estaminal, com tricomas por toda a sua extensão, base com densos tricomas glandulares, anteras amarelas, oblongas, 0,05-0,1 cm compr; ovário $0,14-0,2 \times$ ca. $0,1 \mathrm{~cm}$, subgloboso, piloso, estiletes amarelos, 0,2-0,3 cm compr., parcialmente inclusos no tubo estaminal. Cápsulas obovoides, 0,2-0,3 × 0,2-0,3 mm; sementes $0,05-0,1 \times 0,06-0,1 \mathrm{~cm}$.

Ocorre nos estados da Bahia, Goiás, Mato Grosso do Sul, Minas Gerais, Rio de Janeiro, São Paulo e Paraná (Eggers et al. 2016), alcançando o norte do Paraguai (Chukr \& Capellari Jr. 2003). C7, D6, D7,
F7: campo rupestre e mata de cipó, em altitudes entre 840 e $1020 \mathrm{~m}$. Floresce e frutifica de setembro a dezembro e em abril.

Material selecionado - Jacobina, estrada Araújo para a Serra do Tombador, $11^{\circ} 14^{\prime} 28^{\prime \prime} \mathrm{S}, 40^{\circ} 41^{\prime} 42^{\prime \prime} \mathrm{W}$, nov. 2011, N. Roque 3472 (ALCB); Maracás, fazenda Vale Aprazível, propriedade do Sr. Fernando Carvalho, 1329'06”S, 40²4'26”'W, 22 abr. 2002, K.R.B. Leite et al. 227 (HUEFS); Mirangaba, próximo a Caboré, $10^{\circ} 55^{\prime} \mathrm{S}$, $40^{\circ} 40^{\prime} \mathrm{W}, 1$ set. 1981, L.M.C. Gonçalves 171 (MBM, RB); Morro do Chapéu, Cachoeira do Rio Ferro Doido, trilha que liga a

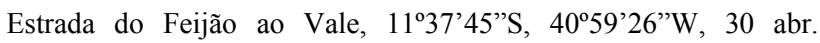
1999, F. França et al. 2760 (HUEFS).

Sisyrinchium commutatum caracteriza-se por possuir folhas e escapo planos, uma bráctea terminal contínua ao escapo e filetes parcialmente soldados com tricomas glandulares, mais densamente agrupados na base do tubo estaminal (Takeuchi et al. 2008). Os materiais analisados para a Bahia confirmam essas características, embora Chukr \& Capellari Jr. (2003) tenham descritos os filetes como totalmente soldados com base em espécimes de São Paulo. Assemelha-se a $S$. nidulare por apresentar folhas e escapo planos, mas distingue-se pelas folhas mais estreitas $(0,1-0,2 \mathrm{~cm}$ vs. 0,4-0,6 cm larg.), escapo com uma única bráctea (vs. 2 brácteas) e estames pilosos (vs. glabros).

\subsection{Sisyrinchium luzula Klotzsch ex Klatt, Linnaea} 31: 89. 1861 .

Figuras 13D-F, 14 e 27C.

Ervas 10 a $45 \mathrm{~cm}$ alt. Folhas 5-12 por planta, 5-26 $\times$ 0,1-0,2 cm, cilíndricas. Escapo 9,5-16,5 cm compr., cilíndrico, ápice portando uma bráctea terminal, oblonga, de $1-2,5 \times 0,1-0,2 \mathrm{~cm}$. Ripídios 1 ou 2 , congestos, sésseis ou subsésseis; espatas $0,4-1 \times 0,2-0,4$ $\mathrm{cm}$. Flores amarelas; tépalas oboval-oblongas, $0,7-1,1 \times$ 0,2-0,5 cm, patentes, nervuras medianas evidentes, castanho-vináceas, ápice acuminado; filetes amarelos, 0,14-0,25 cm compr., unidos até $0,1-0,2 \mathrm{~cm}$ compr., formando tubo estaminal, com tricomas por toda a sua extensão, base com densos tricomas glandulares, anteras amarelas, oblongas, 0,05-0,1 cm compr.; ovário 0,1$0,15 \times$ ca. $0,1 \mathrm{~cm}$, globoso, piloso, estiletes amarelos, $0,2-$ $0,4 \mathrm{~cm}$ compr., unidos até $0,15-0,25 \mathrm{~cm}$, parcialmente inclusos no tubo estaminal. Cápsulas obovoides, $0,3-0,4$ $\times 0,3-0,6 \mathrm{~cm}$; sementes ca. $0,1 \times 0,1 \mathrm{~cm}$.

Ocorre nos estados da Bahia, Mato Grosso, Mato Grosso do Sul, Minas Gerais, São Paulo, Paraná, Santa Catarina e Rio Grande do Sul (Eggers et al. 2016). D6, E6, F6: campo rupestre, cerrado, caatinga e carrasco alto, em altitudes entre 889 e $1450 \mathrm{~m}$. Floresce e frutifica de dezembro a fevereiro e de junho a agosto.

Material selecionado - Abaíra, Distrito de Catolés, Campo de Ouro Fino, 13 ${ }^{\circ} 15^{\prime} \mathrm{S} 41^{\circ} 54^{\prime \prime} \mathrm{W}, 29$ dez. 2013, P.N. Oliveira et al. 108

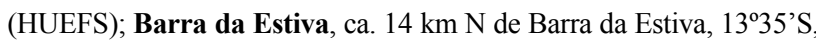
41ํ1'W, 2 fev. 1974, R.M. Harley 15845 (CEPEC, RB); Palmeiras,

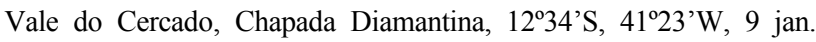
2010, A.A. Conceição 3283 (HUEFS); Morro do Chapéu, rodovia BA-426, Km 6 no sentido Morro do Chapéu/Jacobina, fazenda do Sr. Joaquim Coutinho, 12 ago. 1979, A.J. Ribeiro 47 (CEPEC). 
Sisyrinchium luzula pode ser facilmente reconhecida pelas folhas e escapo cilíndricos (Chukr \& Capellari Jr. 2003; Dias 2010), sendo a única espécie do gênero na Bahia a apresentar tais características. A presença de estruturas vegetativas queimadas nas exsicatas sugere que a floração da espécie ocorra depois da passagem do fogo.

6.3. Sisyrinchium nidulare (Hand.-Mazz.) I.M.Johnst., J. Arnold Arbor. 19: 383. 1938.

Figuras 13G-I e 14.

Ervas $17-38 \mathrm{~cm}$ alt. Folhas $3-8$ por planta, $15-30$ $\times$ 0,4-0,6 cm, planas, lineares, cartáceas, margem espessa. Escapo 11-23 cm compr., plano, ápice portando duas brácteas lineares, planas, a primeira 2,5$16 \times 0,3-0,5 \mathrm{~cm}$, a segunda $3-11 \times 0,3-0,5 \mathrm{~cm}$. Ripídios 3-5, congestos, subsésseis ou pedúnculos até $3,5 \mathrm{~cm}$ compr.; espatas $0,6-1 \times 0,3-0,4 \mathrm{~cm}$. Flores amarelas; tépalas obovais, $1,5-1,6 \times 0,5-0,8 \mathrm{~cm}$, patentes, nervuras medianas evidentes, castanhovináceas, ápice agudo; filetes amarelos, $0,3-0,6 \mathrm{~cm}$ compr., unidos até $0,1-0,3 \mathrm{~cm}$ compr., glabros, anteras amarelas, sagitadas, 0,4-0,6 cm compr., recurvadas na maturidade; ovário $0,1-0,2 \times$ ca. $0,2 \mathrm{~cm}$, subgloboso, glabro, estiletes amarelos, $0,4-0,6 \mathrm{~cm}$ compr., unidos até $0,2-0,3 \mathrm{~cm}$ compr. Cápsulas obovoides, ca. $0,4 \times$ $0,5 \mathrm{~mm}$; sementes $0,05-0,1 \times 0,05-0,1 \mathrm{~cm}$.

Ocorre nos estados da Bahia, Minas Gerais, São Paulo e Paraná (Eggers et al. 2016). E6, F6: campo rupestre e cerrado, na Chapada Diamantina, em altitudes entre 1000 e $1400 \mathrm{~m}$. Floresce e frutifica em maio, julho e dezembro.

Material selecionado - Mucugêe, Serra do Miguel, Parque Nacional da Chapada Diamantina, 12² $49^{\prime}$ 'S, $41^{\circ} 29^{\prime} \mathrm{W}, 12$ maio 2012, A.A. Conceição et al. 4111 (HUEFS); Rio de Contas, Pico das Almas, vertente leste, estrada abaixo da fazenda Silvina, $13^{\circ} 32$ 'S, 41 ${ }^{\circ} 55^{\prime} \mathrm{W}, 20$ dez. 1988, R.M. Harley \& S.J. Mayo 27402 (CEPEC, SPF).

Sisyrinchium nidulare caracteriza-se pelas folhas e escapo planos, ápice do escapo portando duas brácteas, além de estames glabros, com anteras sagitadas. Tem sido erroneamente identificada como $S$. palmifolium L. (Chukr \& Capellari Jr. 2003), que ocorre na Região Sul do Brasil, nos estados do Paraná, Santa Catarina e Rio Grande do Sul (Eggers et al. 2016). Sisyrinchium nidulare difere dessa espécie por apresentar porte menor, até $30 \mathrm{~cm}$ de altura (vs. até até $1,5 \mathrm{~m}$ alt.), margem da folha espessa (vs. delgada) e inflorescência congesta (vs. laxa).

Os exemplares coletados no estado da Bahia demonstram ainda variações quanto ao tamanho de algumas estruturas vegetativas, como hábito, folhas e escapo. Essas variações podem ser resultado de perturbações antrópicas constantes ao longo de sua distribuição.

6.4. Sisyrinchium vaginatum Spreng., Syst. Veg. (ed. 16) [Sprengel] 1: 166. 1825 [1824].

Figuras $15 \mathrm{~A}-\mathrm{H}, 16$ e 27D-G.

Nome popular: capim-lanceta.
Ervas 14-35 cm alt. Folhas basais ausentes. Escapo 12-33 cm compr., plano, simples ou ramificado, com várias brácteas distribuídas por toda a sua extensão; brácteas $0,6-8 \times 0,1-1 \mathrm{~cm}$, planas, escamiformes ou falcadas, alternas, separadas por entrenós. Ripídio 1, terminal ao escapo; espatas 0,7-3 $\times 0,1-0,5 \mathrm{~cm}$. Flores amarelas, tépalas obovais a elípticas, $0,7-1,5 \times 0,2-0,5 \mathrm{~cm}$, patentes, nervuras medianas evidentes, translúcidas, ápice agudo; filetes amarelos, $0,15-0,4 \mathrm{~cm}$ compr., unidos até $0,1-0,5 \mathrm{~cm}$ compr., glabros, anteras amarelas, oblongas, 0,2-0,5 $\mathrm{cm}$ compr., recurvadas na maturidade; ovário $0,1-0,3 \times$ $0,1-0,2 \mathrm{~cm}$, globoso a subgloboso, glabro, estiletes amarelos, 0,2-0,6 cm compr., unidos até $0,1-0,3 \mathrm{~mm}$ compr. Cápsulas obovoides, $0,3-1,2 \times 0,3-1 \mathrm{~mm}$; sementes $0,15-0,2 \times 0,1-0,25 \mathrm{~cm}$.

Sisyrinchium vaginatum é a espécie do gênero com maior distribuição geográfica, ocorrendo desde o México até o Uruguai (Chukr 1988). No Brasil, ocorre no Distrito Federal, Rio de Janeiro, São Paulo, Paraná, Rio Grande do Sul, Santa Catarina (Eggers et al. 2016) e Bahia. D2, D6, E2, E6, E9, F5, F6: brejo, caatinga, campo rupestre e cerrado, em altitudes entre 200 e $1850 \mathrm{~m}$. Floresce e frutifica o ano inteiro, com as flores se abrindo no período da tarde, por volta das 13:00 horas.

Material selecionado - Abaíra, Catolés, Campo de Ouro Fino baixo, $13^{\circ} 15^{\prime}$ 'S, 41 $54^{\prime}$ 'W, 19 jan. 1992, D.J.N. Hind \& R.F. Queiroz H50903 (CEPEC, HUEFS, K, SPF); Alagoinhas, 12 05'47'S, 38²2'06”'W, 24 maio 2010, E. Melo et al. 7929 (HUEFS); Barra da Estiva, estrada Barra da Estiva-Ituaçu, Morro da antena de televisão, 1341'29"S, 41 1919'05'W, 18 maio 1999, V.C. Souza et al. 22661 (ESA); Barreiras, Anel da Soja, estrada para a fazenda São

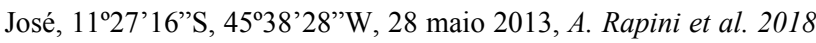
(HUEFS); Camaçari, próximo à rotatória do Polo Petroquímico, atrás do Posto Cegonha, 1240'25”S, 38¹7'58”W, 8 ago. 2013, L.C. Marinho et al. 466 (HUEFS); Caetité, 9,5 km S de Caetité, na rodovia para Brejinhos das Ametistas, $13^{\circ} 07^{\prime} \mathrm{S}, 42^{\circ} 30^{\prime} \mathrm{W}, 13$ abr. 1980, R.M. Harley 21320 (CEPEC); Érico Cardoso, estrada entre

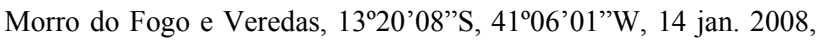
A. Rapini et al. 1521 (HUEFS); Lençóis, Serra da Chapadinha, 1247'44”'S, 41'26'23”'W, 24 fev. 1995, E. Melo et al. PCD 1735 (ALCB, CEPEC, HUEFS); Luiz Eduardo Magalhães, Moriçoca, 29 nov. 2003, A.B. Xavier et al. 230 (ALCB); Morro do Chapéu, Morrão, alto da antena, $11^{\circ} 35^{\prime}$ 'S, $41^{\circ} 12^{\prime} \mathrm{W}, 5$ maio 2007 , M. Freitas et al. 26 (HUEFS); Mucugê, Guiné, Serra do Esbarrancado, 12³1'45”S, 41'34'06”'W, A.A. Conceição 2853 (HUES);

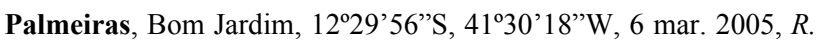
Funch 679 (HUEFS); Piatã, caminho para Três Morros, Ponto 2, 1304'24'S, 4148'14'W, 2 maio 2009, M.L. Guedes et al. 15102 (ALCB); Rio de Contas, estrada para o Pico das Almas,

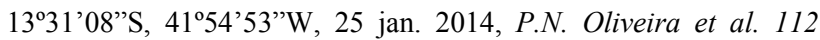
(HUEFS).

Sisyrinchium vaginatum é facilmente reconhecida pela ausência de folhas basais, presença de várias brácteas alternas ao longo do escapo, além dos filetes glabros, unidos até a metade do seu comprimento. Apresenta padrão floral bem definido, mas também uma grande plasticidade fenotípica nas partes 

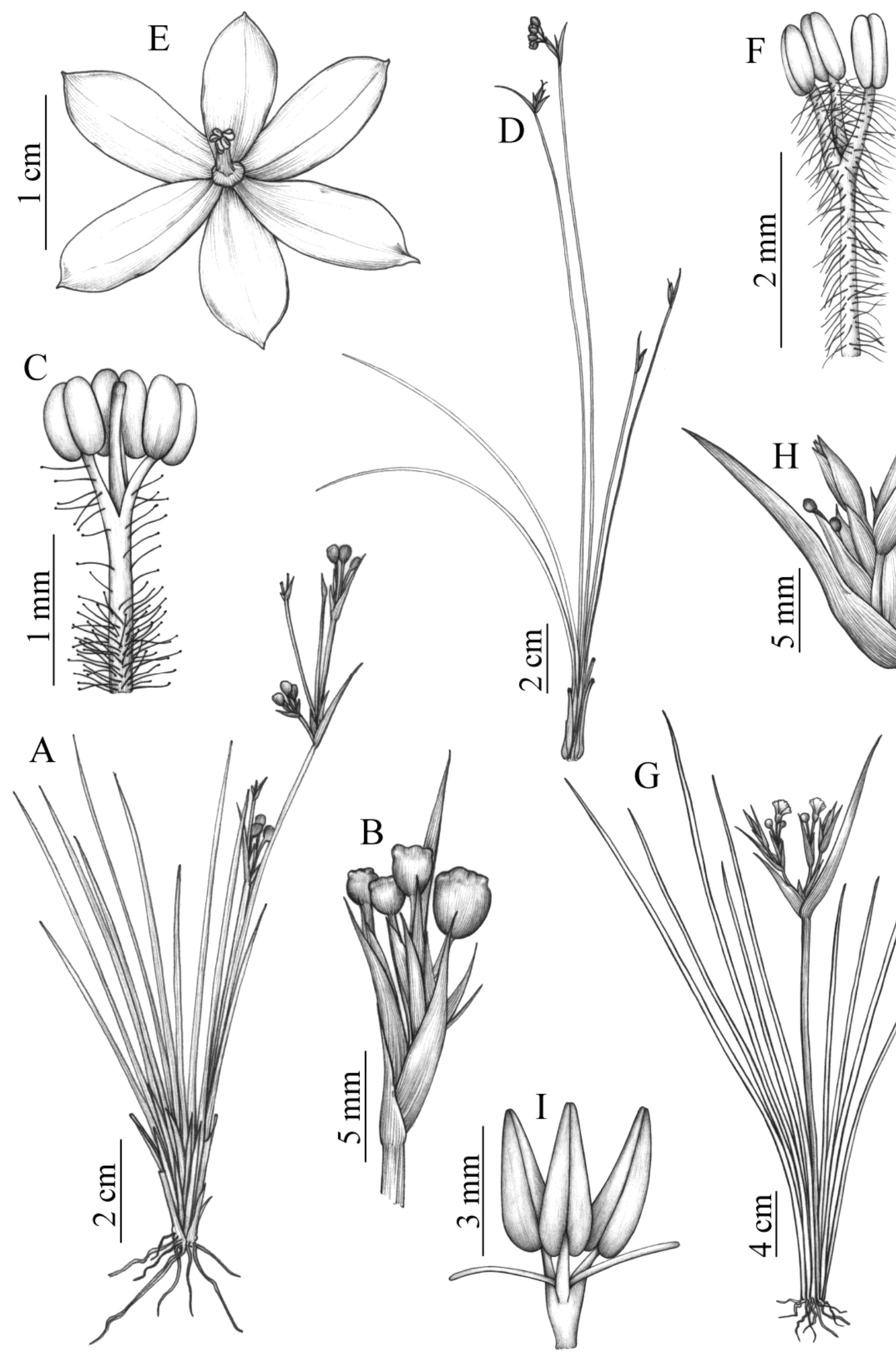


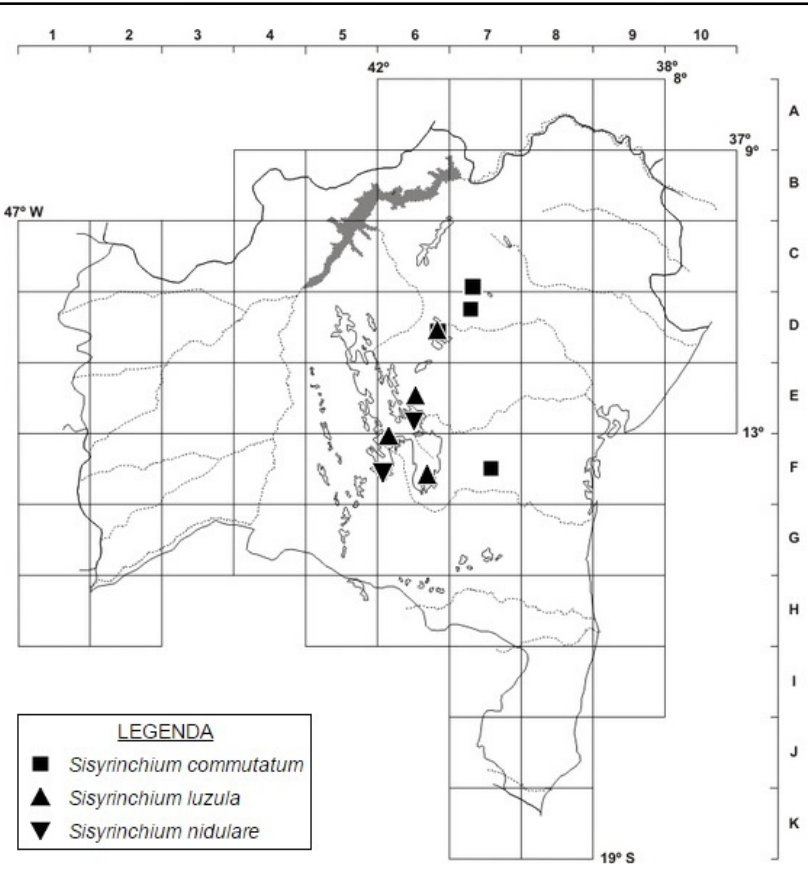

Figura 14. Mapa de distribuição de Sisyrinchium commutatum. S. luzula e S. nidulare no estado da Bahia.

vegetativas, variando principalmente quanto ao tamanho e forma das brácteas (Chukr 1992; Chukr \& Capellari Jr. 2003; Takeuchi et al. 2008; Dias 2010). Assim, é considerada aqui uma espécie polimórfica, ocorrendo em um complexo que precisa ser melhor investigado a partir da integração de abordagens morfológicas e moleculares. Na Bahia, apresenta ampla distribuição e três extremos morfológicos, que geralmente são encontrados nas mesmas localidades. $\mathrm{O}$ primeiro morfotipo é mais semelhante ao material-tipo (Figura 15A, B), sendo ramificado, com brácteas pequenas $(0,6-0,8 \times$ ca. $0,1 \mathrm{~cm})$, reduzidas a escamas $\mathrm{e}$ aderidas completamente ao escapo. O segundo morfotipo (Figura 15E, F) inclui indivíduos pouco ramificados, com brácteas de $1-2 \times 0,2-0,3 \mathrm{~cm}$, fortemente falcadas e não aderidas ao escapo. E o terceiro morfotipo (Figura $15 \mathrm{G}, \mathrm{H}$ ) possui escapo não ramificado, com brácteas grandes $(2,5-8 \times 0,7-1 \mathrm{~cm})$, falcadas e não aderidas completamente ao escapo. Em herbário, pode ser confundida com $S$. restioides Spreng., devido à presença de várias brácteas alternas, mas distingue-se pela ausência de folhas basais.

\section{Trimezia Salisb. ex Herb.}

Ervas com cormo envolto por catafilos fibrosos, castanhos. Folhas espiraladas, planas ou cilíndricas, lineares ou linear-ensiformes, plicadas ou não. Escapos cilíndricos, áfilos ou com 1-7 brácteas em sua extensão. Ripídios terminais ou axilares, laxos, sésseis ou pedunculados; espatas crassas. Flores amarelas ou roxas; tépalas desiguais, as externas maiores, obovais, oboval-elípticas ou lanceoladas, patentes, deflexas ou eretas, região mediano-basal com tricomas e estrias transversais; tépalas internas oboval-oblongas, panduriformes, revolutas, concavidade interna mediana densamente pilosa, estrias transversais por toda a sua extensão; filetes livres, filiformes, achatados, glabros, anteras oblongas ou lineares, opostas e adpressas aos estiletes; ovário oblongo, glabro, estiletes unidos na região mediano-basal, livres no ápice, ramos bífidos ou trífidos, cristas cuspidadas ou truncadas, região estigmática na face interna dos lacínios. Cápsulas oblongas ou oboval-oblongas, ápice truncado; sementes anguladas.

O gênero Trimezia inclui cerca de 20 espécies, distribuídas na porção tropical do continente americano, desde o sul dos Estados Unidos até a Região Sul do Brasil (Chukr \& Giulietti 2008). No Brasil, o gênero está representado por 21 espécies, com ampla distribuição no país, presentes em áreas de campos rupestres, cerrados ou bordas de matas (Eggers et al. 2016). Na Bahia, ocorrem sete espécies, sendo $T$. caulosa endêmica do estado.

\section{Chave para as espécies}

1. Folhas cilíndricas.

2. Escapo sem brácteas 7.4. T. juncifolia

2'. Escapo com duas brácteas ...... 7.2. T. cathartica

1'. Folhas lineares.

3. Escapo sem bráctas; flores lilás .. 7.7. T. violacea

3'. Escapo com 1 a 5 brácteas; flores amarelas.

4. Escapo com 2 a 5 brácteas subcoriáceas

7.6. T. sincorana

4'. Escapo com 1 bráctea foliácea.

5. Bráctea mais longa que o pedúnculo do ripídio; estiletes duplamente bífidos

7.5. T. martinicensis

5'. Bráctea mais curta que o pedúnculo do ripídio; estiletes trífidos.

6. Cristas do estilete longo-triangulares (plantas de campos rupestres)

\subsection{T. brevicaulis}

6'. Cristas do estilete truncadas, levemente franjadas (plantas da mata atlântica)

7.3. T. caulosa

\subsection{Trimezia brevicaulis Ravenna, Bol. Soc. Argent.} Bot. 10. 321. 1965.

Figuras $17 \mathrm{~A}-\mathrm{D}$ e 18.

Ervas 0,2-0,33 m alt.; cormo 0,8-1 $\times 0,5-0,7 \mathrm{~cm}$. Folhas $1-4$ por planta, $10-22 \times 0,1-0,3 \mathrm{~cm}$, lineares, cartáceas. Escapo $2-10 \mathrm{~cm}$ compr., ápice portando uma bráctea, menor que o comprimento do pedúnculo do ripídio, linear-ensiforme, $2-4 \times 0,3-0,5 \mathrm{~cm}$. Ripídio 1; pedúnculo 7-16 cm compr.; espatas 1,5-2 ×0,6-0,8 $\mathrm{cm}$. Flores amarelas; tépalas externas obovais a oboval-elípticas, $1-1,8 \times 0,7-1,2 \mathrm{~cm}$, patentes ou reflexas, com estrias castanho-vináceas na base; tépalas internas 1,2-1,5 × 0,3-0,4 cm, eretas, estrias castanhovináceas em toda a sua extensão; filetes castanhos, 0,2-0,4 cm compr., anteras amarelas, oblongoelípticas, 0,2-0,35 cm compr.; ovário ca. 0,5 × 0,1-0,2 $\mathrm{cm}$, estiletes amarelos, ca. 0,7 compr., unidos até ca. 


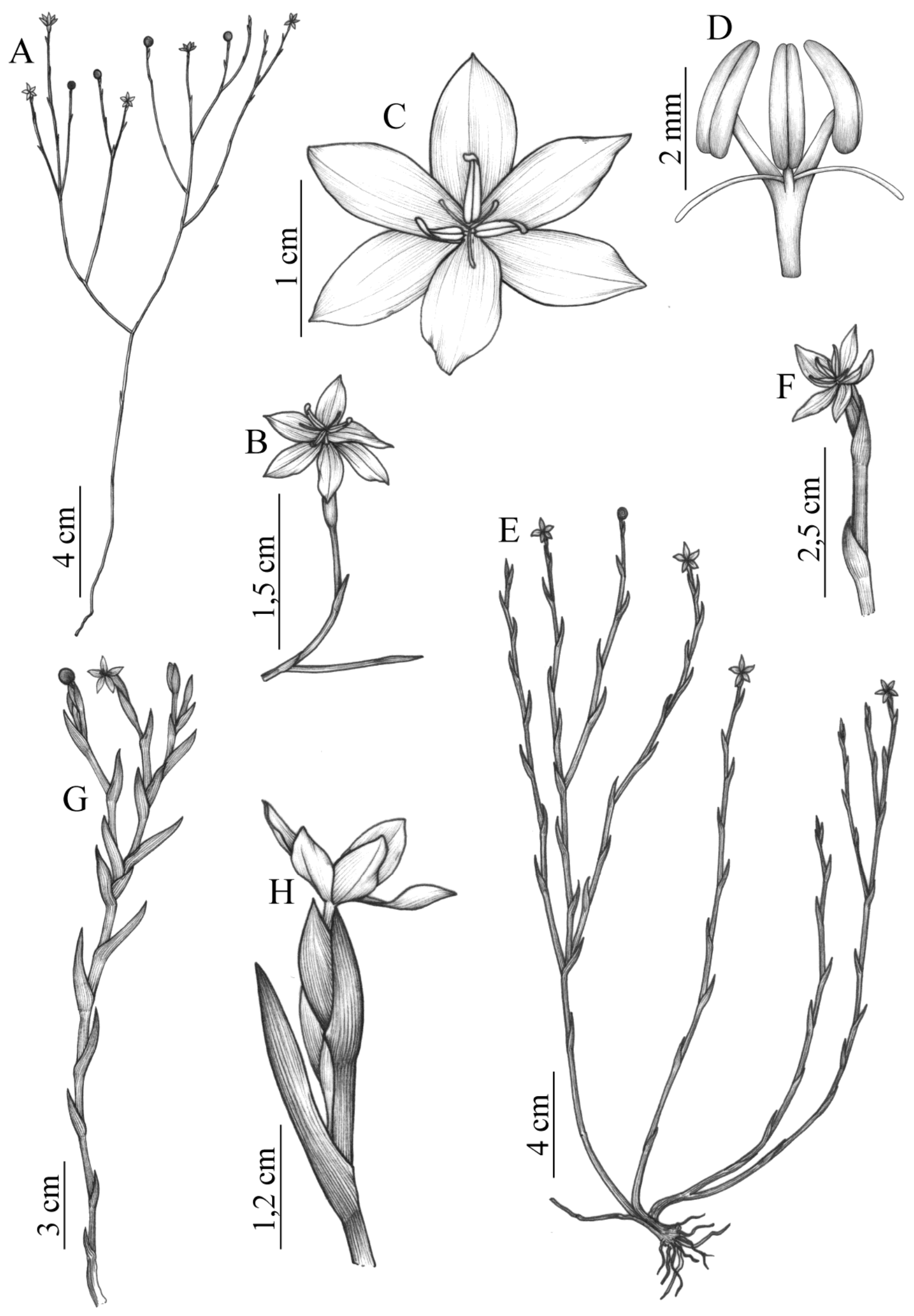

Figura 15. A-H. Sisyrinchium vaginatum: A, E, G- hábito; B, F, H- inflorescência; C- flor, vista frontal; D- estames e estiletes. (A, B- Santos 33 HUEFS; C, D- Oliveira 112 HUEFS; E, F- Hind H50903 CEPEC; G- Freitas 26 HUEFS; H- Melo 3327 HUEFS). 
0,5 cm compr., base cilíndrica, região mediano-apical globosa, ramos trífidos, cristas longo-triangulares, ápice filiforme, as laterais ca. 0,2 cm compr., a central $0,13-0,15 \mathrm{~cm}$ compr. Cápsulas oblongas, $1-1,5 \times 0,5$ $1 \mathrm{~cm}$; sementes ca. $0,2 \times 0,1 \mathrm{~cm}$.

Restrita à Cadeia do Espinhaço, do norte de Minas Gerais ao norte da Chapada Diamantina, na Bahia (Chukr \& Giulietti 2008). E6: campo rupestre, em altitude entre 1400 e $1700 \mathrm{~m}$. Floresce e frutifica de setembro a março.

Material selecionado - Palmeiras, PARNA, $12^{\circ} 42^{\prime} \mathrm{S}$, 41³1'W, 4 mar. 2006, A.A. Conceição 1742 (HUEFS). Mucugê, Morro do Beco, $12^{\circ} 45^{\prime}$ 'S, $41^{\circ} 30^{\prime} \mathrm{W}, 15$ set. 2006, A.A. Conceição et al. 1839 (HUEFS).

Trimezia brevicaulis caracteriza-se pelo porte pequeno (20-33 cm alt.), o menor dentre as espécies do gênero na Bahia, a presença de uma bráctea pequena (2-4 cm compr.), sempre excedida pelo pedúnculo do ripídio, e pelos estiletes com ramos trífidos e cristas longo-triangulares de ápice filiforme. Chukr \& Giulietti (2008) indicaram que a espécie apresenta escapo densamente piloso, característica que não foi observada nos espécimes da Bahia, as quais exibem escapo glabro. Pela morfologia vegetativa, assemelhase a $T$. caulosa e $T$. martinicensis, diferenciando-se delas principalmente por seus atributos florais. Trimezia brevicaulis possui estiletes com ramos trífidos, com cristas longo-triangulares, diferentemente de $T$. caulosa, onde estes são trífidos e truncados, levemente franjados, e de $T$. martinicensis, que apresenta estiletes duplamente bífidos.

7.2. Trimezia cathartica (Klatt) Niederl., Bol. Mens. Mus. Prod. Argent. 3, 31: 332. 1890.

Figuras 17E-I, 18 e 27H, I.

Nome popular: robalo.

Ervas 0,4-1,2 m alt.; cormo 2,5-5 × 1-2,5 cm. Folhas $1-5$ por planta, $12-67 \times 2-5 \mathrm{~cm}$, cilíndricas, eretas. Escapo 12,5-52 cm compr., ápice portando duas brácteas alternas, lanceoladas, a primeira $5-24,5 \mathrm{~cm}$ compr., a segunda 3-6,5 cm compr., algumas vezes separadas entre si por um entrenó de 2,5-13 cm compr., distantes 8-26 cm da inflorescência. Ripídios 1 ou 2; pedúnculo 16-59 cm compr.; espatas 2-3,5 × 1-1,3 cm. Flores amarelas; tépalas externas obovais, 2,5-3,5 × 3 $3,6 \mathrm{~cm}$, patentes, ápice obtuso, com tricomas filamentosos, base com estrias castanho-vináceas; tépalas internas oboval-oblongas, $2-3,3 \times 0,5-0,6 \mathrm{~cm}$, com estrias castanho-vináceas por toda a sua extensão; filetes amarelos, 0,5-1 cm compr., anteras esverdeadas, oblongas, 0,5-0,7 cm compr.; ovário 0,8-1 × 0,2-0,3 cm, estiletes amarelos, 1,3-1,5 cm compr., unidos até ca. 0,8 cm compr., cilíndricos na base, região mediano-apical alargada, ramos trífidos, cristas estreito-triangulares, ápice arredondado, as laterais 0,13-0,2 cm compr., a central $0,05-0,08 \mathrm{~cm}$ compr. Cápsulas oblongas, $0,8-1 \times 0,3-$ $0,5 \mathrm{~cm}$; sementes $0,1-0,4 \times$ ca. $0,1 \mathrm{~cm}$.

Ocorre nos estados de Minas Gerais, Bahia e Goiás (Chukr \& Giulietti 2008). E2, E6, F6, G2: campo

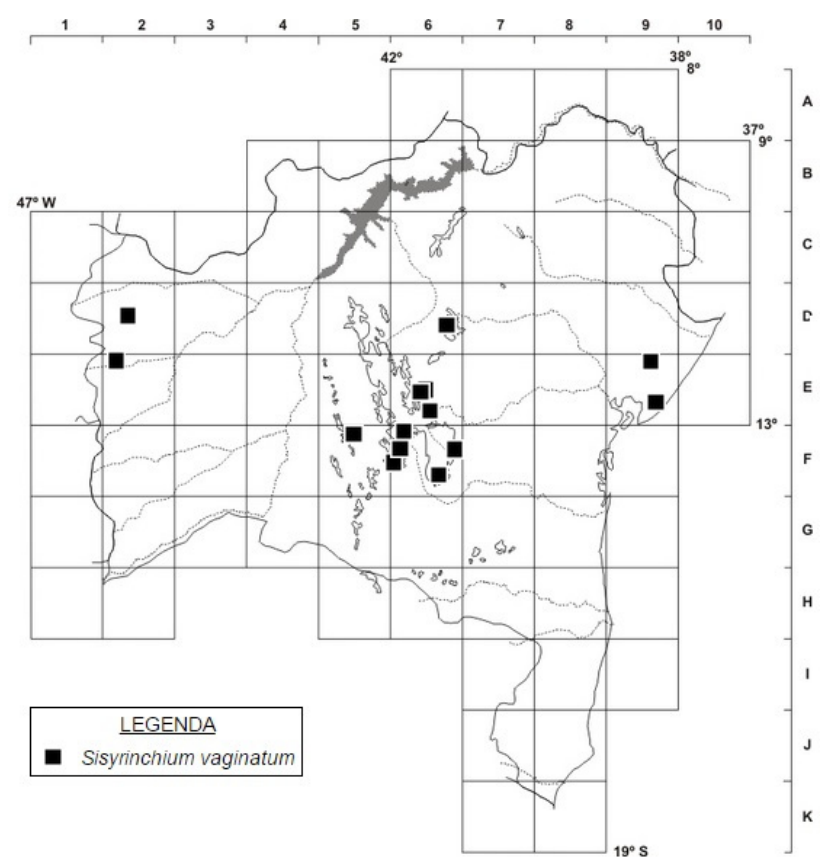

Figura 16. Mapa de distribuição de Sisyrinchium vaginatum no estado da Bahia.

rupestre, campos gerais com caatinga, campo sujo e cerrado, na Chapada Diamantina, em altitudes de 900 a $1800 \mathrm{~m}$. Floresce e frutifica o ano todo.

Material selecionado - Abaíra, Catolés, Campo de Ouro Fino, 13¹5'27'S, 4153'57''W, 29 dez. 2013, P.N. Oliveira 109 (HUEFS); Barra da Estiva, estrada Barra da Estiva-Ituaçu,

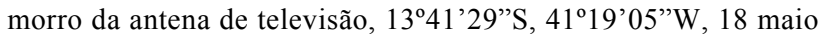
1999, V.C. Souza et al. 22694 (ESA); Cocos, fazenda Trijunção, estrada para a fazenda Olhos d'Água, $14^{\circ} 52^{\prime}$ 'S, $45^{\circ} 56^{\prime} \mathrm{W}, 11 \mathrm{dez}$. 2001, B.M.T. Walter et al. 4936 (SPF); Lençóis, Morro do Pai Inácio, Platô Intermediário, 27 ago. 1996, A.A. Conceição \& A.A. Grillo 140 (CEPEC, SPF); Luiz Eduardo Magalhães, fazenda Savaí, ca. $40 \mathrm{~km}$ da cidade, $12^{\circ} 13^{\prime} 27^{\prime \prime} \mathrm{S}, 45^{\circ} 49^{\prime} 59^{\prime \prime} \mathrm{W}$, 22 set. 2003, B.A. Anjos et al. 105 (ALCB) Palmeiras, Parque Nacional da Chapada Diamantina, Serra da Fumaça, 12³6'08"S, 41'29'18”'W, 20 mar. 2012, G. Almeida-Silva \& F.G. Moreira 196 (HUEFS); Piatã, estrada Piatã-Ribeirão, 1307'15"S, 4149'34”'W, 1 nov. 1996, H.P. Bautista et al. PCD 3877 (SPF); Mucugê, Guiné, $12^{\circ} 51^{\prime}$ 'S, $41^{\circ} 30^{\prime} \mathrm{W}, 21$ out. 2002, E.C. Smidt 297 (HUEFS); Rio de Contas, Pico das Almas, vertente leste, campo acima do extremo NW do Campo do Queiroz, 1331's, 41 ${ }^{\circ} 58^{\prime}$ 'W, 22 dez. 1988, R.M. Harley et al. 27421 (CEPEC, K, SPF).

Trimezia cathartica caracteriza-se por apresentar folhas cilíndricas, escapo com duas brácteas alternas na região apical, e estiletes com ramos trífidos e cristas estreito-triangulares. Muitas vezes, é confundida com $T$. juncifolia em coleções de herbário, devido às folhas cilíndricas e à morfologia floral similar, mas difere facilmente desta por seu escapo áfilo. Apresenta grande variação fenotípica no comprimento de folhas e escapos. Em Rio de Contas, ocorrem tanto indivíduos com folhas de 11$32 \mathrm{~cm}$ compr. (e.g., Harley 54527), quanto indivíduos com folhas até $64 \mathrm{~cm}$ (e.g., Côrtes 80). 

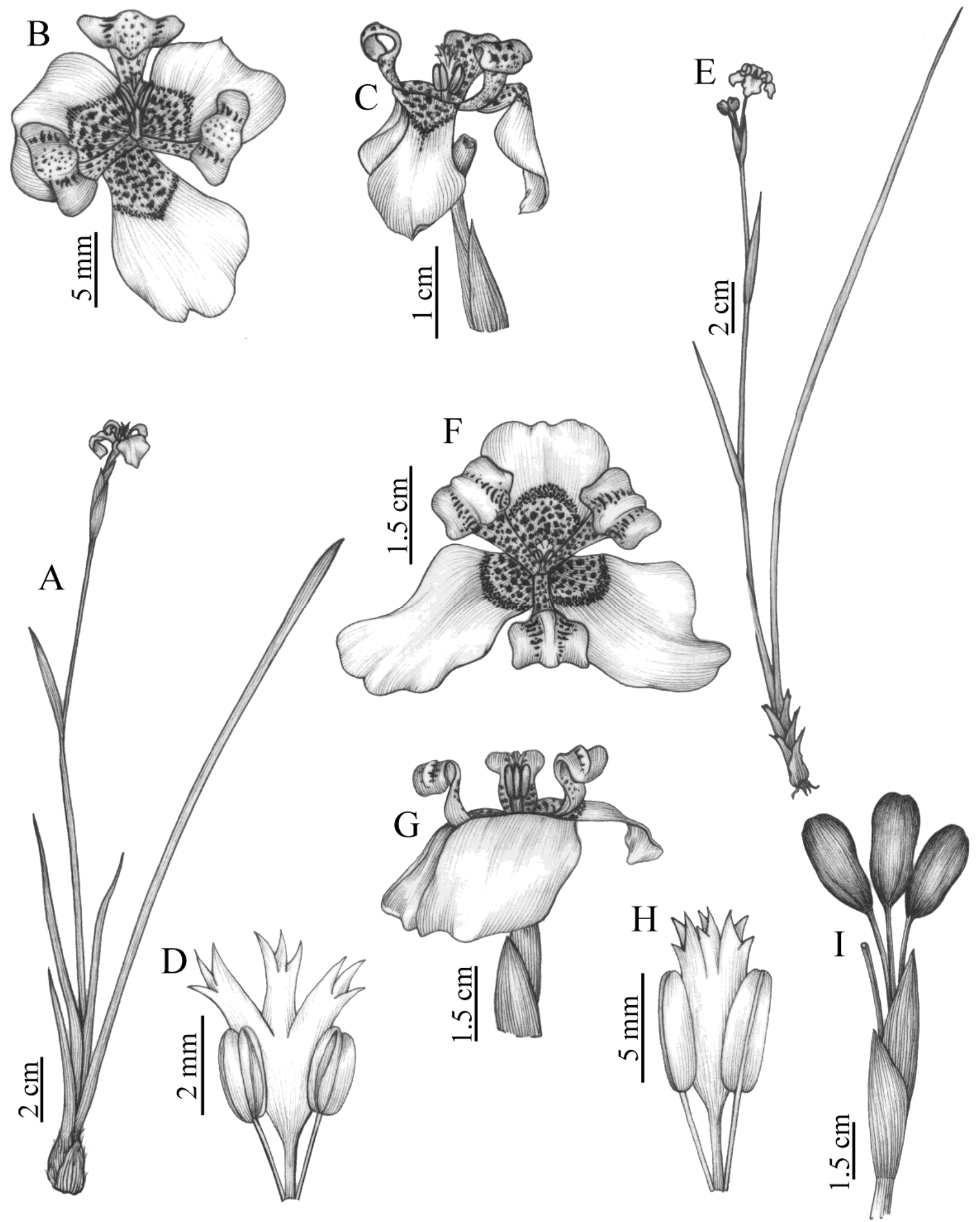

Figura 17. A-D. Trimezia brevicaulis: A- hábito; B- flor, vista frontal; C- flor, vista lateral; D- estames e estiletes. E-I- T. cathartica: E- hábito; F- flor, vista frontal; G- flor, vista lateral; H- estames e estiletes; I- ripídio com frutos maduros. (A-D- Conceição 1742 HUEFS; E- Harley 27421 CEPEC; F-H- Oliveira 109 HUEFS; I- Conceição 140 SPF).

7.3. Trimezia caulosa Ravenna, Wrightia 7(2): 94. linear-ensiformes, membranáceas, nervura mediana 1982.

Figuras 18, 19A-D e 28A-C.

Ervas $0,4-1,2 \mathrm{~m}$ alt., cormo $1-2 \times 0,5-2 \mathrm{~cm}$. Folhas $1-7$ por planta, $8-120 \times 0,4-1,5 \mathrm{~cm}$, lineares ou proeminente. Escapo 3,5-26 cm compr., ápice portando uma bráctea menor que o comprimento do pedúnculo do ripídio, linear-ensiforme, 3-45 × 0,5-1,5 $\mathrm{cm}$, foliácea. Ripídios 1 ou 2; pedúnculo $11-55 \mathrm{~cm}$ 
compr.; espatas 2,2-3,5 × 0,5-1 cm. Flores amarelas; tépalas externas obovais, $1,8-2,3 \times 0,5-1 \mathrm{~cm}$, eretas, côncavas, ápice trilabiado, região mediano-apical revoluta, região basal com estrias castanhas; tépalas internas oboval-oblongas, $1,2-1,5 \times 0,6-0,8 \mathrm{~cm}$, eretas, com estrias castanhas em toda a sua extensão, ápice truncado; filetes amarelos, 0,3-0,6 cm compr., anteras amarelas, oblongas, $0,3-0,4 \mathrm{~cm}$ compr.; ovário ca. 0,5 $\times 0,1-0,2 \mathrm{~cm}$, estiletes amarelos, 0,7-1 cm compr., unidos até $0,6-0,8 \mathrm{~cm}$ compr., base cilíndrica, região mediano-apical globosa, ramos trífidos, cristas truncadas, levemente franjadas, as laterais ca. $0,1 \mathrm{~cm}$ compr., a central ca. $0,3 \mathrm{~mm}$ compr. Cápsulas oblongas, $0,6-1,2 \times 0,2-0,3 \mathrm{~cm}$; sementes $0,2-0,4 \times$ $0,2-0,3 \mathrm{~cm}$.

Endêmica do Litoral Sul da Bahia, em região de mata atlântica, mas com distribuição mais ampla do que a originalmente fornecida por Ravenna (1982). F/G8, G8, H8, I8: floresta ombrófila, floresta de tabuleiros e mata higrófila, em altitude de 40 a $100 \mathrm{~m}$. Floresce e frutifica de julho a janeiro, com as flores se abrindo no período da manhã e fechando por volta das 14:00 horas.

Material selecionado - Camamu, fazenda Brahma, 19 dez. 1985, T.S. Santos 3979 (CEPEC, RB, SPF); Ilhéus, estrada IlhéusItacaré, ramal fazenda Ponta Grossa, em direção à Lagoa Encantada, 14³6'01'S, 38¹1'24”'W, 14 fev. 2014, P.N. Oliveira 115 (HUEFS); Itacaré, ca, $8 \mathrm{~km} \mathrm{SW}$ de Itacaré, rodovia ItacaréUbaitaba, 14'20'S, 39 03'W, 31 jan. 1977, R.M. Harley 18432 (CEPEC, MBM, SPF); Santa Cruz Cabrália, Reserva Biológica Pau-Brasil, 15 set. 1971, T.S. Santos 1924 (isótipo CEPEC); Porto Seguro, rodovia BR-367, a $16 \mathrm{~km} \mathrm{~W}$ de Porto Seguro, próximo à Estação Ecológica do Pau-Brasil, 3 nov. 1978, A. Euponino 368 (parátipo CEPEC, SPF); Una, fazenda Bolandeira, 15²3'14”'S, 3905'46”'W, 21 out. 2011, E. Matos 3345 (HUEFS).

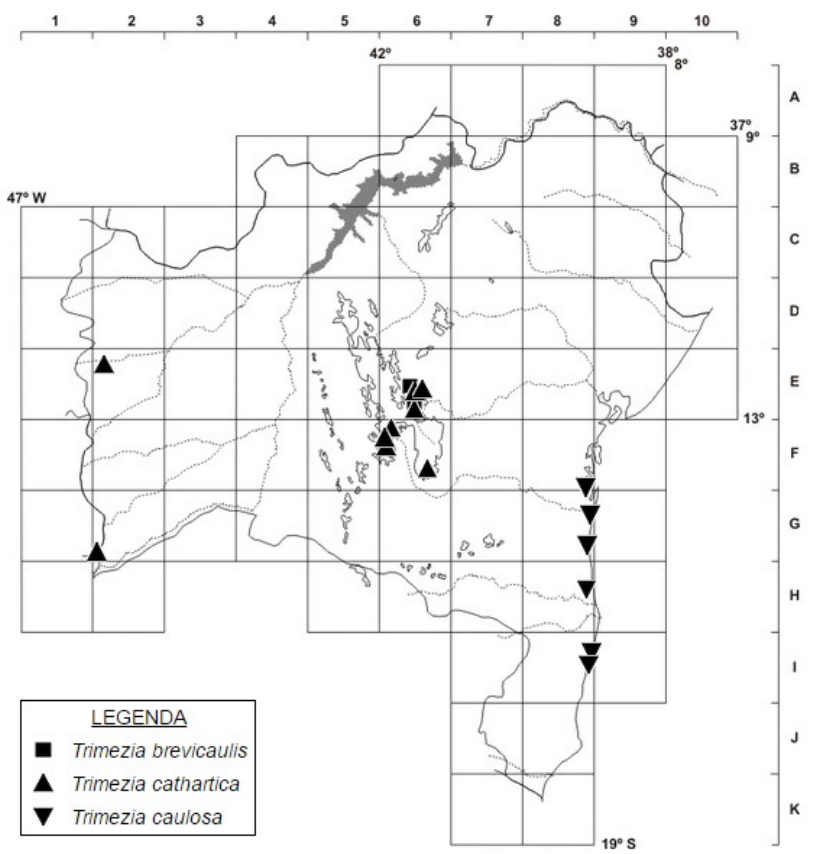

Figura 18. Mapa de distribuição de Trimezia brevicaulis, T. cathartica e T. caulosa no estado da Bahia.
Ravenna (1982), ao descrever Trimezia caulosa caracterizou o ramo florífero como sendo cilíndrico (teres). Entretanto, Chukr \& Giulietti (2001), ao analisarem o isótipo T.S. Santos 1924 (CEPEC) e o parátipo Espunino 368 (CEPEC), consideraram que a espécie apresentava filotaxia equitante e escapo achatado, transferindo a mesma para o gênero Neomarica. Em contrapartida, Gil (2012), em revisão do gênero, indicou que o escapo cilíndrico é conspícuo, como descrito por Ravenna, e que os estudos filogenéticos com a tribo Trimezieae suportam a inclusão da espécie em Trimezia, posicionamento aceito no presente trabalho. A espécie caracteriza-se por possuir uma bráctea inserida no escapo, com comprimento menor que o pedúnculo do ripídio e flores amarelas, com tépalas eretas e côncavas na porção basal, com forma semelhante à de uma taça, e região mediano-apical revoluta. Apresenta grande variação fenotípica quanto ao porte dos indivíduos, além do comprimento de folhas, escapo e bráctea. Os indivíduos de maior porte foram encontrados ao sul da Bahia, nos municípios de Porto Seguro e Santa Cruz Cabrália, com folhas de 70-120 $\mathrm{cm}$ de comprimento, enquanto os materiais de menor porte estão concentrados nos municípios de Ilhéus, Itacaré, Una e Camamu, com folhas de 11-45 cm de comprimento.

\subsection{Trimezia juncifolia (Klatt) Benth. \& Hook.f.,} Gen. Pl. [Bentham \& Hooker f.] 3(2): 690. 1883.

Figuras 19, 20 e 28D.

Ervas $0,25-0,57 \mathrm{~m}$ alt.; cormo $1-2 \times 1-1,5 \mathrm{~cm}$. Folhas 1 ou 2 por planta, $10-52 \times 0,3-0,5 \mathrm{~cm}$, cilíndricas, eretas, rígidas. Escapo $12-55 \mathrm{~cm}$ compr., áfilo. Ripídio 1; espatas $2-3 \times 0,5-1 \mathrm{~cm}$. Flores amarelas a alaranjadas; tépalas externas obovalelípticas, 2,3-3,5 $\times 1-2 \mathrm{~cm}$, patentes, base com tricomas capitados e estrias transversais castanhovináceas; tépalas internas oboval-oblongas, $1-2,1 \times$ $0,4-1 \mathrm{~cm}$, eretas, ápice obtuso, estrias transversais castanho-vináceas em toda a sua extensão; filetes amarelos, ca. 0,5 cm compr., anteras amarelas ou verdes, oblongas, ca, $0,75 \mathrm{~cm}$ compr.; ovário $0,4-1 \times$ 0,15-0,25 cm, estiletes amarelos, ca. $1,4 \mathrm{~cm}$ compr., unidos até $0,5-1 \mathrm{~cm}$ compr., com região basal cilíndrica, região mediano-apical alargada, ramos trífidos, cristas curto-triangulares, ápice agudo, as laterais ca. 0,2 cm compr., a central ca. $0,05 \mathrm{~mm}$ compr. Cápsulas ovoides ou oboval-oblongas, 1-2 $\times$ $0,5-1,5 \mathrm{~cm}$; sementes $2,5-3 \times 1-3 \mathrm{~mm}$.

Amplamente distribuída nos estados de Goiás, Mato Grosso, Mato Grosso do Sul, Minas Gerais e mais raramente em São Paulo e Paraná (Chukr \& Giulietti 2008; Eggers et al. 2016), sendo este o seu primeiro registro para a Bahia, no oeste do estado. F2: cerrado. Floresce em outubro.

Material examinado - Correntina, vereda próximo ao Rio das Éguas, $13^{\circ} 30^{\prime}$ 'S $, 45^{\circ} 35^{\prime} \mathrm{W}, 17$ out. 1989, R.C. Mendonça et al. 1562 (UB). 


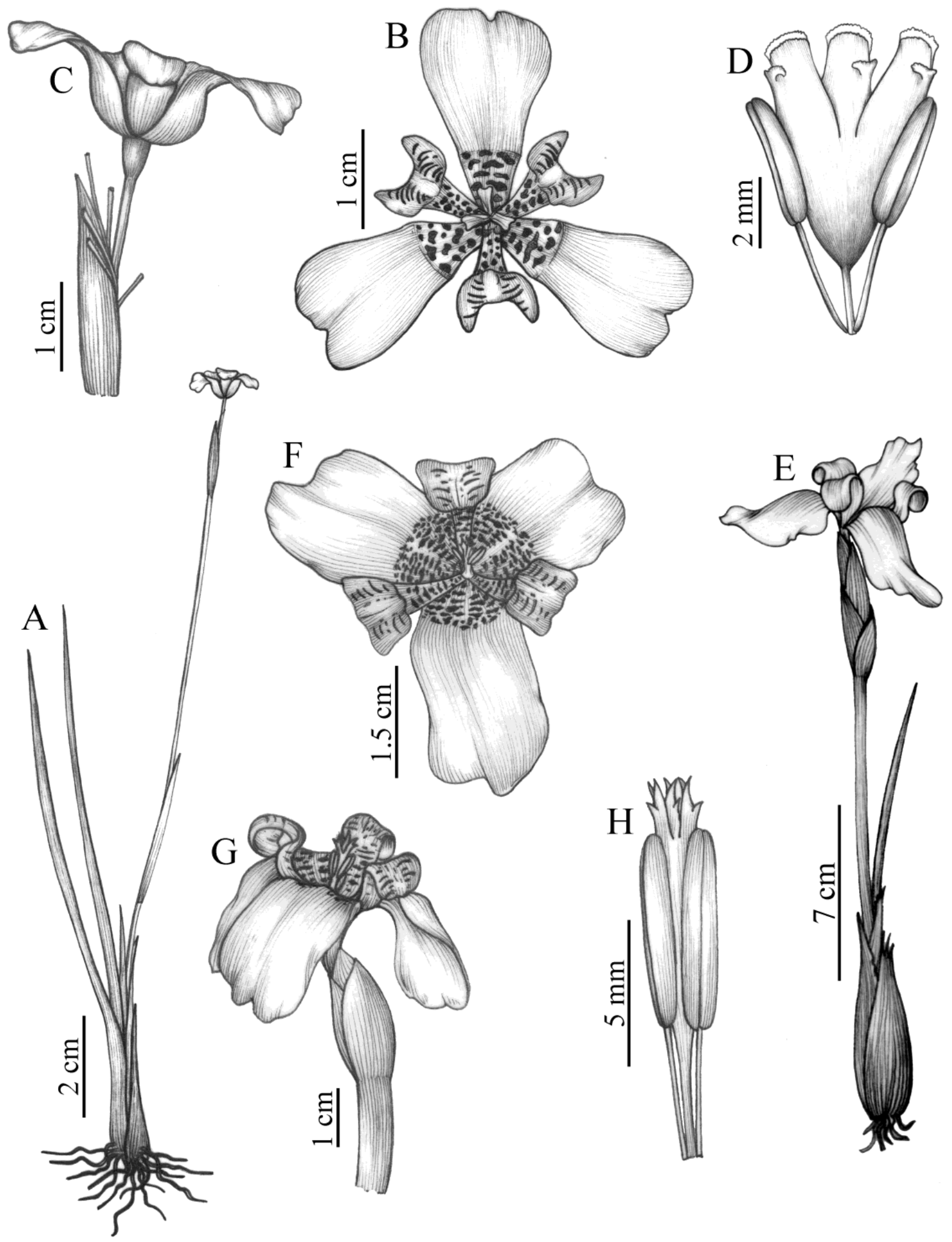

Figura 19. A-D. Trimezia caulosa: A- hábito; B- flor, vista frontal; C- flor, vista lateral; D- estames e estiletes. E-H- T. juncifolia: E- hábito; F- flor, vista frontal; G- flor, vista lateral; H- estames e estiletes. (A-D- Oliveira 115 HUEFS; E, F- Mendonça 1562 UB; G-I- van den Berg 1262 HUEFS).

Material adicional - BRASIL. GOIÁS: Pirenópolis, Ponto 9, Serra dos Pirineus, $15 \mathrm{~km}$ de estrada a direta de Cocalzinho, 1547'47'S, 4849'51'W, 11 fev. 2004, C. van den Berg 1262 (HUEFS). MINAS GERAIS: São Roque de Minas, Parque Nacional da Serra da Canastra, estrada São Roque de Minas-Sacramento, ca. de $2 \mathrm{~km}$ da nascente do rio São Francisco, 15 dez. 1998, M.A. Farinaccio \& E.M. Campos Filho 233 (SPF); Santana do Riacho, Serra do Cipó, rodovia Belo Horizonte-Conceição do Mato Dentro, 
km 131, 16 jan. 1987, N.S. Chukr \& A.P. Godoy s.n. (MBM 267001, SPF 46971); SÃO PAULO: Itirapina, próximo ao pedágio, Represa do Broa, 22 ${ }^{\circ} 10^{\prime} 52^{\prime}$ 'S, $47^{\circ} 52^{\prime} 48^{\prime \prime} \mathrm{W}, 7$ dez. 1994, K.D. Barreto et al. 3348 (ESA).

Trimezia juncifolia distingue-se pelas folhas cilíndricas, de onde lhe advém o epíteto específico, além do escapo áfilo e as flores alaranjadas, caracteres que a diferenciam de $T$. cathartica, espécie mais semelhante morfologicamente. De acordo com os espécimes analisados, é a espécie de Trimezia com menor frequência na Bahia, com apenas uma coleta no estado, em área de cerrado. As medidas das flores, frutos e sementes foram feitas a partir dos materiais adicionais.

7.5. Trimezia martinicensis (Jacq.) Herb., Edwards's Bot. Reg. misc. 88. 1844.

$=$ Trimezia connata Ravenna, Wrightia 7: 91. 1982.

Figuras 20, 21A-D, e 28E, F.

Nome popular: íris-miúda.

Ervas $0,3-0,5 \mathrm{~m}$ alt; cormo $1-2 \times 0,5-1,5 \mathrm{~cm}$. Folhas $1-7$ por planta, $12-63 \times 0,3-1 \mathrm{~cm}$, lineares, membranáceas, nervura mediana proeminente. Escapo 5-45 cm compr., ápice portando uma bráctea maior ou aproximadamente igual ao comprimento do pedúnculo do ripídio, linear-ensiforme, 9-50 × 0,3-1 cm, foliácea, nervura mediana proeminente. Ripídios 1-3; pedúnculo 7-40 cm compr.; espatas $1-1,5 \times 0,3-0,5$ $\mathrm{cm}$. Flores amarelas; tépalas externas obovais a elíptico-ovais, $1,7-2 \times 0,6-0,7 \mathrm{~cm}$, eretas, côncavas, ápice emarginado com tricomas filamentosos, região basal com estrias castanhas, tépalas internas oblongas, $1,2-1,4 \times 0,3-0,5 \mathrm{~cm}$, eretas, ápice obtuso, acuminado, com tricomas filamentosos, estrias castanhas em toda a sua extensão; filetes amarelos, 0,4-0,6 cm compr., anteras castanhas, oblongas, $0,3-0,4 \mathrm{~cm}$ compr.; ovário $0,3-0,4 \times 0,1-0,2 \mathrm{~cm}$, estiletes amarelos, ca. $0,8 \mathrm{~cm}$ compr., unidos até ca. $0,3 \mathrm{~cm}$ compr., base cilíndrica, região mediano-apical globosa, ramos duplamente bífidos, cristas curto-triangulares, ápice agudo, laterais e centrais ca. $0,1 \mathrm{~mm}$ compr. Cápsulas oblongas, $0,7-$ $2 \times 0,3-0,5 \mathrm{~cm}$; sementes $0,2-0,4 \times 0,2-0,3 \mathrm{~cm}$.

Apresenta a maior distribuição geográfica dentre as espécies do gênero, ocorrendo na América Central, Brasil e Venezuela (Chukr \& Giulietti 2008). No Brasil, é indicada para o estado do Amazonas e, na região leste brasileira, do Piauí a Santa Catarina (Chukr \& Giulietti 2008; Eggers et al 2016), podendo ocorrer como planta invasora, principalmente em gramados (Capellari Jr. 2005). C6, D6, E8, E9, E10, F6, F8, F8/9, G5, G8, H8: campo rupestre, caatinga, cerrado, floresta atlântica, floresta estacional semidecidual, mata ciliar e restinga, em altitudes até $1120 \mathrm{~m}$, geralmente a pleno sol, formando grandes populações em locais antropizados, próximos à beira de estradas. Floresce e frutifica o ano todo, com as flores se abrindo pela manhã e se fechando por volta das 14:00 horas.

Material selecionado - Abaíra, Serra em Catolés de Cima, 30 maio 1994, F. França et al. 1047 (HUEFS, SPF); Amargosa, fazenda Timbó-Palmeirinha, área 6, centro Sapucaia, $13^{\circ} 10^{\prime} \mathrm{S}$, 3909'W, 17 mar. 2007, J.L. Paixão et al. 1117 (HUEFS); Cairu, Morro do São Paulo, 13²4’38”S, 3854'53”W, 27 out. 1996, M.L. Guedes \& M. Acioly 4826 (ALCB); Camaçari, às margens do rio Capivara, 12²41'S, 39²9'W, 10 ago. 1999, M.L. Guedes \& F.A. Mendonça 6479 (ALCB); Camamu, fazenda Brahma, próximo a $14^{\circ} 09^{\prime} 05^{\prime}$ 'S, 39²1'04”'W, 2 fev. 2006, A. Gil et al. 182 (UEC); Conde, Fazenda do Bu, Trilha da Reflora, $12^{\circ} 0$ '27'S, 37\%42'08'W, 13 ago. 1996, M.C. Ferreira et al. 1022 (RB); Elísio Medrado, Projeto Gambá, Reserva do Jequitibá, estrada de acesso da captação de água, 1252'S, 39²8'W, 23 set. 2003, C. van den Berg 1009 (HUEFS); Entre Rios, Pau de Umbigo, em frente à estrada da

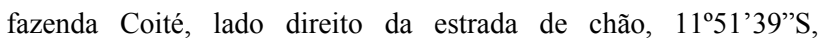
$38^{\circ} 01^{\prime} 09^{\prime \prime} \mathrm{W}, 8$ out. 2014, P.N. Oliveira 119 (HUEFS); Feira de Santana, Campus da UEFS, $12^{\circ} 58^{\prime} \mathrm{S}, 38^{\circ} 58^{\prime} \mathrm{W}, 7$ jun. 2001, L.P. Queiroz 6632 (HUEFS); Ibirapitanga, rodovia BR-330, trecho BR101-Ubatã, a $10 \mathrm{~km}$ do entroncamento para Ibirapitanga, 4 maio 1979, S.A. Mori \& T.S. Santos 11772 (RB); Igrapiúna, povoado Laranjeiras, 13'54'19'S, 39¹2'28'W, 17 jul. 2010, M.L. Guedes et al. 17252 (ALCB); Ilhéus, estrada Itacaré, ca. $6 \mathrm{~km}$ da ponte da beira da estrada, $14^{\circ} 47^{\prime}$ S, $39^{\circ} 12^{\prime} \mathrm{W}, 22$ maio 2007, M.M. SilvaCastro et al. 1202 (HUEFS); Itacaré, ca. $8 \mathrm{~km}$ SW de Itacaré, rodovia Itacaré-Ubaitaba, $14^{\circ} 18^{\prime} 32^{\prime}$ 'S, 39 02 ' $15^{\prime}$ 'W, 14 fev. 2014, P.N. Oliveira et al. 117 (HUEFS); Ituberá, assentamento Josidei Hipólito, Km 15 da rodovia Ituberá-Gandu, 30 jun. 2002, L.A. Mattos-Silva \& B.R. Santos 4551 (ALCB, CEPEC, UESC); Licínio de Almeida, estrada para Caetité, 1436'32"S, 42³1'55”W, 3 nov. 2006, A. Rapini \& R. Souza-Silva 1319 (HUEFS); Morro do Chapéu, rodovia BA-426, Km 6 no sentido Morro do Chapéu/Jacobina, fazenda do Sr. Joaquim Coutinho, 12 ago. 1979, A.J. Ribeiro 45 (CEPEC); Salvador, Dunas de Itapuã, 1256'S, $38^{\circ} 21^{\prime}$ 'W, jan. 1980, L.R. Noblick 1616 (ESA, HUEFS); Serrinha, próximo à Torre da Embratel, povoado Barra do Vento, $11^{\circ} 37^{\prime} 45^{\prime}$ "S, $39^{\circ} 04^{\prime} 75^{\prime}$ W, 5 ago. 2014, P.N. Oliveira et al. 121 (HUEFS); Ubirataia, mata próxima à Torre, entre o povoado de Mineiros e Algodão, 1353'29”'S, 3941'04”'W, 21 jul. 2013, L.Y.S. Aona et al.

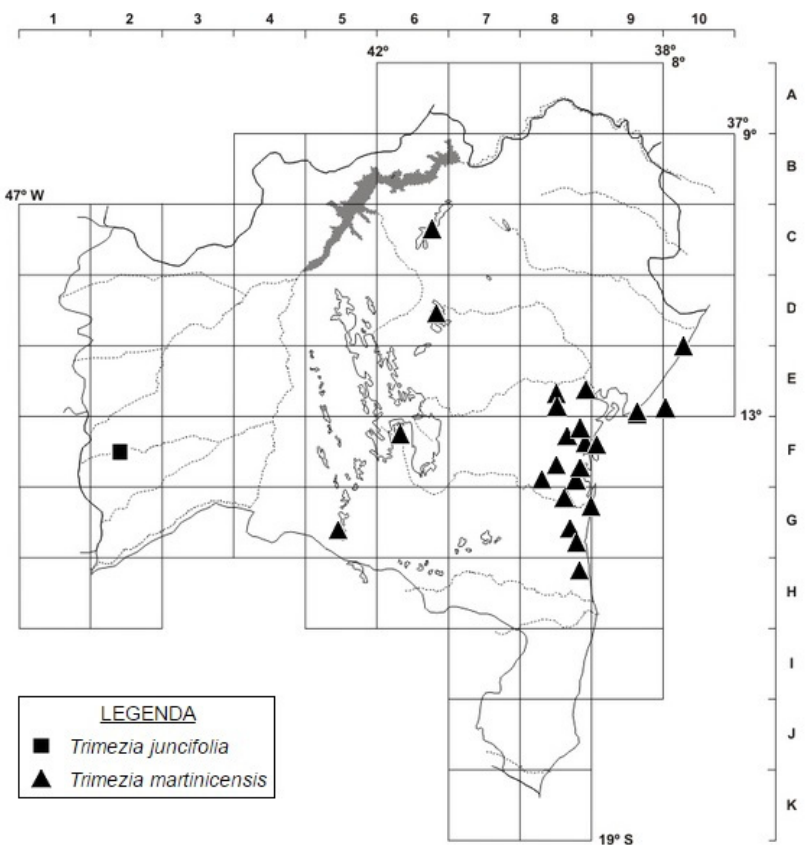

Figura 20. Mapa de distribuição de Trimezia juncifolia e T. martinicensis no estado da Bahia. 
2862 (HUEFS, RB); Umburanas, Serra do Curral Feio (Serra da Empreitada), Cachoeirinha, à beira do rio Tabuleiro, ca. $10 \mathrm{~km} \mathrm{NW}$ de Delfino, na estrada que sai pelo depósito de lixo, $10^{\circ} 21^{\prime} \mathrm{S}$,

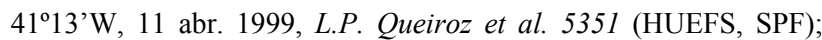
Una, Reserva Biológica de Una, Piedade, 1510'36”S, 3908'38”'W, 15 ago. 1998, A. Martini \& D.G. Santos 38 (CEPEC, UESC); Uruçuca, Distrito de Serra Grande, arredores da Sede do Distrito, 1-12 jul. 1991, A.M. Carvalho et al. 3501 (CEPEC); Valença, entroncamento da rodovia BA-542 com a BR-101, 13²16'49'S, 39¹9'50"W, 4 set. 2006, A.M. Amorim \& W.D. Rocha 6267 (CEPEC); Wenceslau Guimarães, Reserva Estadual, próximo ao Pico do Urubu, 2 abr. 1993, L.A.M. Silva \& S.C. Sant'Ana 2937 (CEPEC).

Trimezia martinicensis é a espécie-tipo do gênero e pode ser reconhecida pela presença de uma única bráctea, sendo esta maior ou aproximadamente igual ao comprimento do pedúnculo do ripídio, e pelas flores amarelas com tépalas eretas e côncavas, conferindo à flor um aspecto globoso. Apresenta considerável variação fenotípica relacionada ao porte dos indivíduos e ao comprimento das folhas, com espécimes robustos, portando folhas de 33-40 $\mathrm{cm}$ de comprimento (e.g., Carvalho 3223), e outros delicados, portando folhas de 18-24 cm de comprimento (e.g., Melo 3445 e Queiroz 5351). É semelhante vegetativamente a T. brevicaulis e T. caulosa, pois as três espécies possuem uma única bráctea, de onde partem as inflorescências pedunculadas. Elas diferem pela presença de uma bráctea geralmente com comprimento maior ou aproximadamente igual ao do pedúnculo do ripídio e os estiletes duplamente bífidos em $T$. martinicensis, enquanto em $T$. brevicaulis e $T$. caulosa, a bráctea apresenta comprimento menor que o pedúnculo do ripídio e os estiletes são trífidos e longo-triangulares em $T$. brevicaulis e trífidos e truncados em $T$. caulosa.

Ravenna (1982) descreveu Trimezia connata a partir de material de Morro do Chapéu (Ribeiro 45, CEPEC), caracterizando-a com tépalas externas fortemente aderidas entre si por apículos. Após análise do holótipo e de outros materiais identificados pelo autor da espécie, não foram encontradas diferenças morfológicas em relação a $T$. martinicensis, principalmente em relação às tépalas externas, nas quais não se evidenciaram os apículos, nem nos estiletes. Esta análise concorda com Chukr \& Giulietti (2008), que propuseram a sinonimização de $T$. connata e $T$. martinicensis, posição não adotada na Flora do Brasil (Eggers et al. 2016), que aceita $T$. connata.

7.6. Trimezia sincorana Ravenna, Wrightia 7(2): 90. 1982.

Figuras 21E-H, 22 e 28G, H.

Ervas 0,4-2,5 m alt.; cormo $2-5 \times 2-2,5 \mathrm{~cm}$. Folhas $2-6$ por planta, $25-180 \times 0,5-2 \mathrm{~cm}$, lineares, coriáceas, nervura mediana proeminente. Escapo 11$50 \mathrm{~cm}$ compr., portando várias brácteas, subcoriáceas, 2-7 por planta, a primeira linear-ensiforme, 4,5-25 $\times$
0,8- $1 \mathrm{~cm}$, as demais linear-ensiformes a falcadas, 1,5$9,5 \times 0,5-1 \mathrm{~cm}$, separadas por entrenós de 6,3-27 cm compr. Ripídios 4-6; pedúnculo 6,5-38 cm compr.; espatas 1,5- 3,6 × 0,4-1 cm. Flores amarelas; tépalas externas oboval-elípticas, 1,6-3 × 1-2,4 cm, base com estrias castanho-vináceas e tricomas capitados; tépalas internas oboval-oblongas, $1,5-1,8 \times 0,5-0,7 \mathrm{~cm}$, com estrias vináceas em toda a sua extensão; filetes castanhos, 0,3-0,4 cm compr., anteras castanhas, ca. $0,4 \mathrm{~cm}$ compr; ovário $0,3-0,4 \times 0,1-0,2 \mathrm{~cm}$, estiletes amarelos, 0,8-1,1 cm compr., unidos até $0,5 \mathrm{~cm}$ compr., base cilíndrica, região mediano-apical globosa, ramos trífidos, cristas longo-triangulares, ápice acuminado, as laterais ca. $1 \mathrm{~mm}$ compr., a central ca. $0,5 \mathrm{~mm}$ compr. Cápsulas oblongas, $1,4-2 \times 0,5-1 \mathrm{~cm}$; sementes ca. $0,2 \mathrm{~cm} \times 0,2-0,3 \mathrm{~cm}$.

Presente nos estados da Bahia e Minas Gerais (Chukr \& Giulietti 2008). C6, D3, D6/7, D7, E6, E7, F6, J8: campo rupestre, caatinga, cerrado, mata ciliar, mata de encosta e mata higrófila, em altitudes de 515 a $1163 \mathrm{~m}$. Floresce e frutifica o ano todo, com as flores se abrindo pela manhã.

Material selecionado - Abaíra, estrada Catolés-Barra, 10-11 km de Catolés, 12 mar. 1992, B. Stannard et al. H51891 (CEPEC, HUEFS, SPF); Andaraí, caminho para a antiga estrada para Xique-Xique do Igatú, 1252'15”S, 41¹8’25”W, 14 fev. 1997, $L$. Passos et al. PCD 5655 (CEPEC, HUEFS); Itaetê, Chapadinha, 12'33'01'S, 41'23'33”'W, 21, fev. 2004, R. Funch 121 (HUEFS); Itamaraju, fazenda Pau-Brasil, ca. $5 \mathrm{~km}$ a NW de Itamaraju, 19 set. 1978, S. Mori et al. 10729 (CEPEC); Itaberaba, Serra do

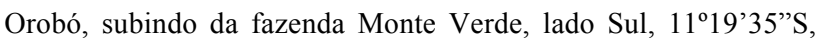
4411'31'W, 13 mar. 1999, R.M. Harley et al. 53506 (HUEFS);

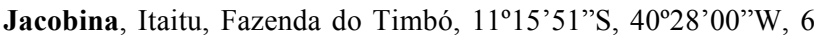
set. 1999, Melo et al. 3002 (HUEFS); Lençóis, Chapadinha,

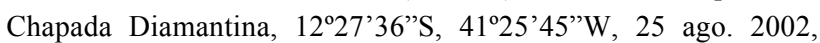
M.J.G. Andrade \& M.E.R. Junqueira 126 (HUEFS); Morro do Chapéu, Cachoeira do Ferro Doido, alto da cachoeira,

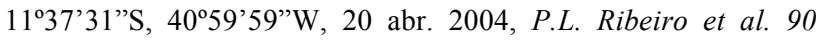
(HUEFS); Mucugê, primeira entrada à esquerda, próxima à

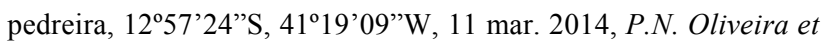
al. 118 (HUEFS); Palmeiras, Morro do Pai Inácio, 12²7'20"S, 4128'15”W, 25 out. 1994, A.M. Amorim et al. PCD 953 (CEPEC, HUEFS, SPF); Rio de Contas, $8 \mathrm{~km} \mathrm{E}$ da cidade, na estrada para Juciape, 1336'S, 4145'W, 25 nov. 1988, R.M. Harley et al. 26999 (CEPEC, HUEFS, K, SPF); Ruy Barbosa, trilha para o Pátio das Orquídeas, $12^{\circ} 18^{\prime} 14$ "S, 40²8'58”'W, 28 jul. 2004, L.P. Queiroz et al. 9396 (HUEFS); Seabra, Serra do Bebedor, a $40 \mathrm{~km}$ de Seabra, 15 nov. 1983, J.C. Lima 314 (CEPEC, HUEFS, RB); Sento Sé, entre Almas de Cima e Minas do Mimoso, 10¹9'18'S, 41'23'48' W, 1 maio 2002, K.R.B. Leite et al. 165 (HUEFS).

Trimezia sincorana caracteriza-se por apresentar folhas coriáceas, com nervura mediana proeminente, e escapo portando de duas a sete brácteas, que se associam ao pedúnculo dos ripídios num crescimento monopodial em ziguezague, sendo as últimas linearensiformes ou falcadas. Com base em características morfológicas, Chukr \& Giulietti (2008) consideraram $T$. sincorana como subespécie de $T$. spathata Baker, Trimezia spathata subsp. sincorana (Ravenna) Chukr, 


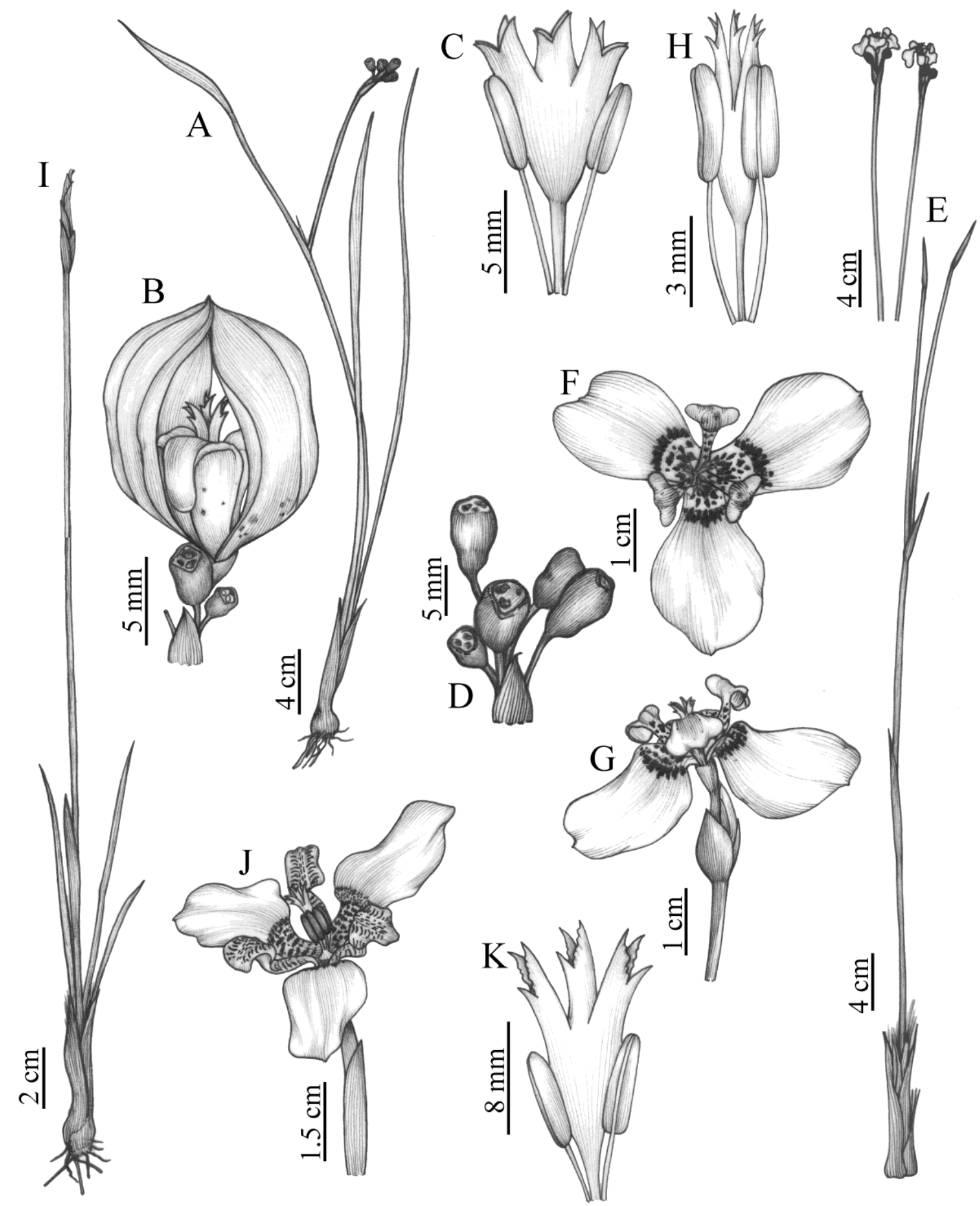

Figura 21. A-D. Trimezia martinicensis: A- hábito; B- flor, vista lateral; C- estames e estiletes; D- frutos. E-H- T. sincorana: E- hábito; Fflor, vista frontal; G- flor, vista lateral; H- estames e estiletes. I-K. T. violacea: I- hábito; J- flor, vista lateral; K- estames e estiletes. (A, DOliveira 117 HUEFS; B, C- Oliveira 119 HUEFS; E- Harley 26999 (CEPEC); F, G- Melo 3002 HUEFS; H- Andrade 126 HUEFS; I- Harley 27647 CEPEC; J-K- Garnev s.n. HUEFS 13721).

diferenciando-se das outras subespécies pelo porte maior, folhas em tonalidade verde-escura, coriáceas, nervura mediana proeminente e número de brácteas variando entre duas a sete. Contudo, estudos filogenéticos com a tribo Trimezieae (Lovo et al. 2012) indicaram que esses táxons não estão proximamente relacionados e devem ser considerados em espécies distintas, posicionamento adotado aqui. 
Trimezia sincorana apresenta grande variação fenotípica no comprimento das folhas e brácteas. Indivíduos com porte maior apresentam mais brácteas e inflorescências, conferindo um aspecto mais laxo à planta. Por exemplo, o material Queiroz 9396 apresentou indivíduos maiores, com folhas de 75-100 $\mathrm{cm}$ de comprimento e escapo com cinco brácteas, enquanto o material Cardoso 410 apresentou indivíduos delicados, com folhas de $25-30 \mathrm{~cm}$ de comprimento e escapo com duas brácteas.

7.7. Trimezia violacea (Klatt) Ravenna, Rev. Inst. Munic. Bot. [Buenos Aires] 2: 60.1962 [1964].

Figuras 21I-K, 22 e 28I.

Ervas 0,6-1 m alt.; cormo $2-3 \times 0,4-0,6 \mathrm{~cm}$. Folhas $1-5$ por planta, $43-65 \times 0,2-0,5 \mathrm{~cm}$, lineares, nervura mediana proeminente. Escapo $54-90 \mathrm{~cm}$, áfilo. Ripídio 1; espatas 2-3,5 × 0,6-1 cm. Flores lilás; tépalas externas oboval-elípticas, 2,7-4,5 × ca. 2 $\mathrm{cm}$, base ereta, com tricomas capitados e estrias transversais violeta, porção apical reflexa; tépalas internas oblongo-obovais, 2,8-3 $\times$ ca. $1 \mathrm{~cm}$, estrias violeta em toda a sua extensão, mancha amarelada na concavidade interna, ápice obtuso; filetes amarelos, 0,5-0,8 cm compr., anteras negras, oblongas, 0,8-0,9 cm compr.; ovário $0,5-0,8 \times 0,1-0,2 \mathrm{~cm}$, estiletes violetas, ca. 1,5 cm compr., unidos até 1,0-1,3 cm compr., região mediano-apical alargada, ramos trífidos, cristas curto-triangulares, ápice agudo, as laterais ca. 0,3 cm compr., levemente franjadas, a central ca. 0,2 $\mathrm{mm}$ compr. Cápsulas oboval-elipsoides, 1,2-1,8 $\times$ $0,7-0,9 \mathrm{~cm}$; sementes $0,3-0,4 \times 0,2-0,3 \mathrm{~cm}$.

Ocorre nos estados da Bahia e Minas Gerais (Chukr \& Giulietti 2008), sendo indicada também para Goiás e Distrito Federal (Eggers et al. 2016). F6: campo

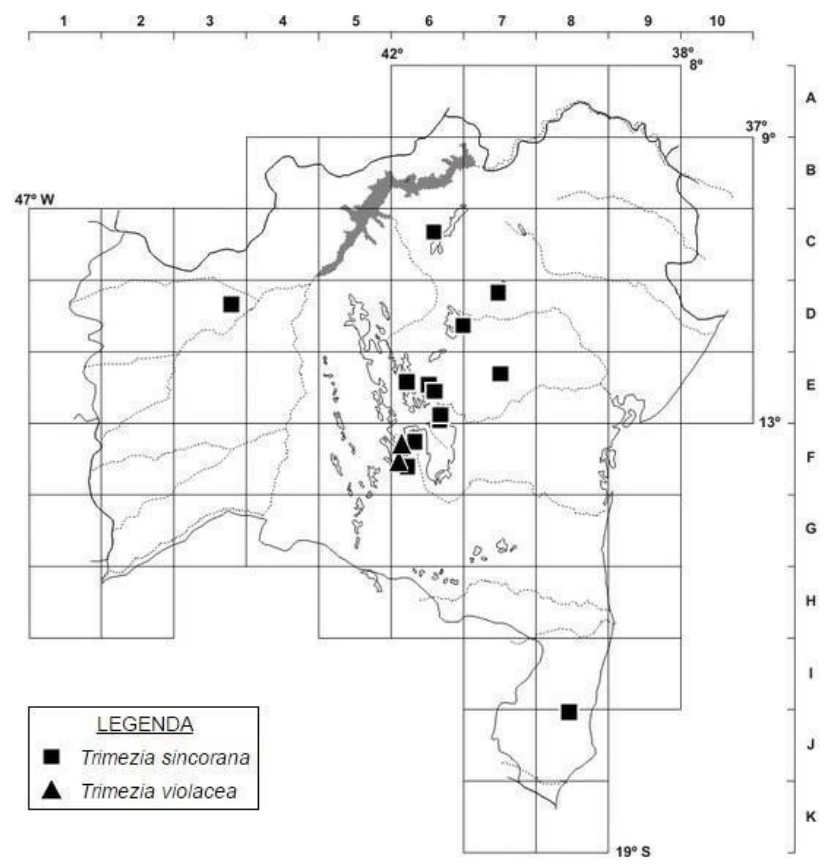

Figura 22. Mapa de distribuição de Trimezia sincorana e T. violacea no estado daBahia. rupestre, na região sul da Chapada Diamantina, em altitudes acima de $1000 \mathrm{~m}$. Floresce e frutifica em dezembro.

Material examinado - Abaíra, Distrito de Catolés, dez. 1992, W. Ganev s.n. (HUEFS 13721); Rio de Contas, Pico das Almas, vertente leste, Junco, $13^{\circ} 32$ 'S, 41 ${ }^{\circ} 53^{\prime}$ 'W, 21 dez. 1988, R.M. Harley \& B. Stannard 27647 (CEPEC, SPF).

Trimezia violacea é facilmente identificável por apresentar folhas lineares, escapo áfilo e flores de cor lilás, caráter pouco comum no gênero. Existem somente duas coletas no estado, não sendo recoletada desde 1992. Suas populações possuem poucos indivíduos, o que levou Ravenna (1977) a considerá-la em vias de extinção. O pequeno número de catafilos fibrosos quando comparado ao das demais espécies de Trimezia sugere um período de vida relativamente mais curto ou a não formação da parte aérea em todos os anos, o que pode contribuir para o risco de extinção da espécie.

\section{Agradecimentos}

À Universidade Estadual de Feira de Santana (UEFS), pela infraestrutura disponibilizada para a execução deste trabalho; aos curadores dos herbários, pelo acesso às coleções; à Carla de Lima, pela ilustração, e ao Lucas Marinho, pela montagem das pranchas de ilustração; ao $\mathrm{CNPq}$, pelas bolsas de produtividade concedidas a AMG e RPO (PQ Senior e PQ1D, respectivamente) e pela bolsa de MSc para a primeira autora. As autoras também agradecem à FAPESB, pelo apoio financeiro ao projeto Flora da Bahia (FAPESB APR 162/2007), e ao CNPq, pelo apoio à Flora da Bahia (processos 562278/2010-9 e 483909/2012-2), Reflora (563858/2010-5) e PPBIO/ Semiárido.

\section{REFERÊNCIAS}

Alves, L.I.F.; Lima, S.A.A. \& Felix, L.P. 2011. Chromosome characterization and variability in some Iridaceae from Northeastern Brazil. Genetics and Molecular Biology 34(2): 259-267.

APG IV. 2016. An update of the Angiosperm Phylogeny Group classification for the orders and families of flowering plants. Botanical Journal of the Linnean Society 181(1): 1-20.

Aublet, J.B.C.F. 1775. Histoire des Plantes de la Guiane Françoise. Vol. 1. P.F. Didot Paris.

Capellari Jr., L. 2000. Revisão Taxonômica do Gênero Neomarica Sprague (Tribo Mariceae, Subfamília Iridoideae, Iridaceae). Tese de Doutorado em Biologia Vegetal, Instituto de Biologia da Universidade Estadual de Campinas.

Capellari Jr., L. 2005. Iridaceae da planície litorânea de Picinguaba, Ubatuba, São Paulo. Hoehnea 32: 207-213.

Chukr, N.S. 1988. A Família Iridaceae na Serra do Cipó, Minas Gerais (Brasil). Dissertação de Mestrado. Instituto Biociências da Universidade de São Paulo. 


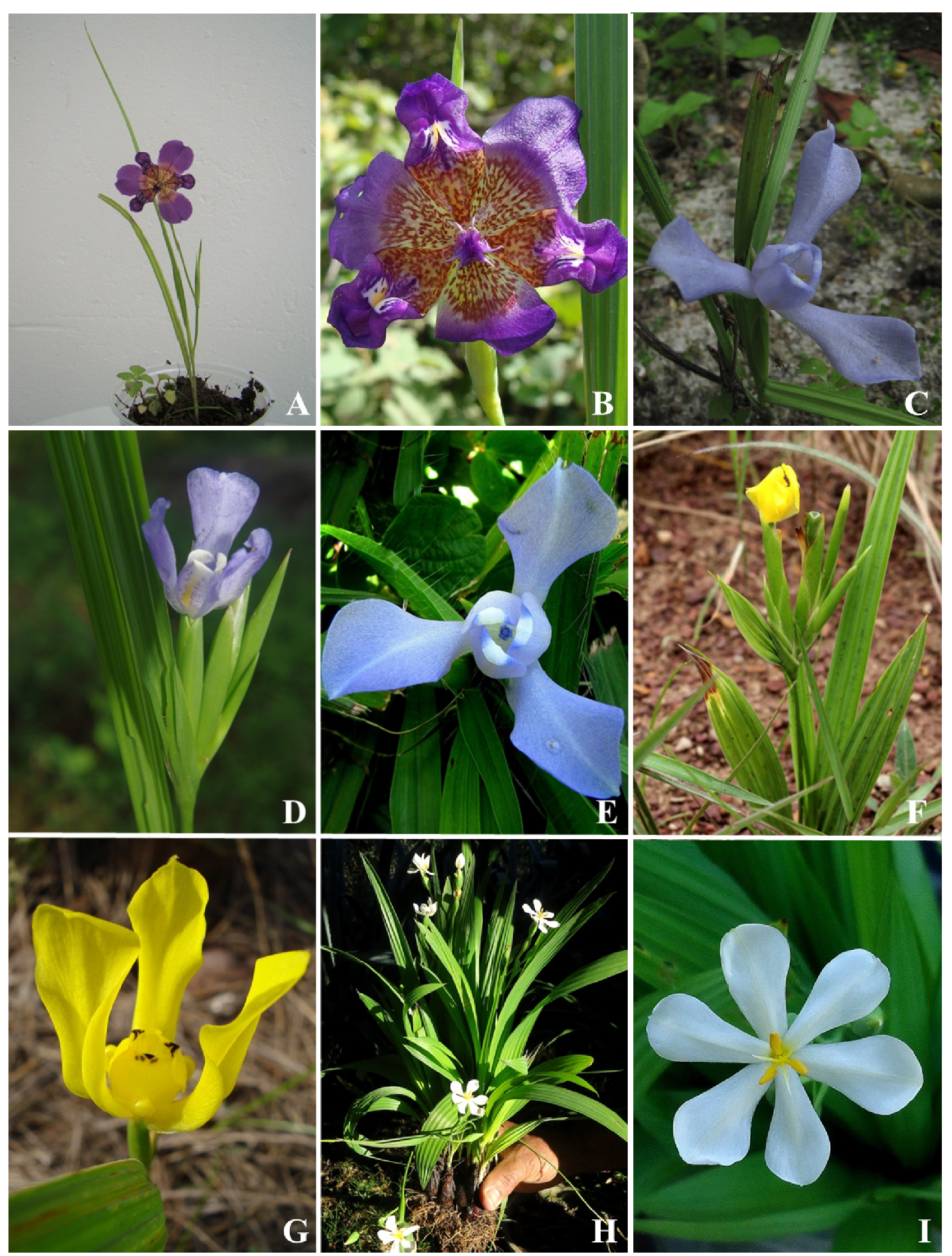

Figura 23. A, B. Alophia drummondii: A- hábito em cultivo; B- flor, vista frontal. C-E. Cipura paludosa: C- hábito; D- inflorescência com flor, vista lateral; E- flor, vista frontal. F, G. C. xanthomelas: F- hábito; G- flor, vista lateral. H, I. Eleutherine bulbosa: H- hábito; I- flor, vista frontal. (Fotos: A- Pamela N. Oliveira; B- Ana Maria Giulietti; C, H, I- Alex Popovkin; D, G- C.F. Hall; E, F- Maurício Mercadante). 


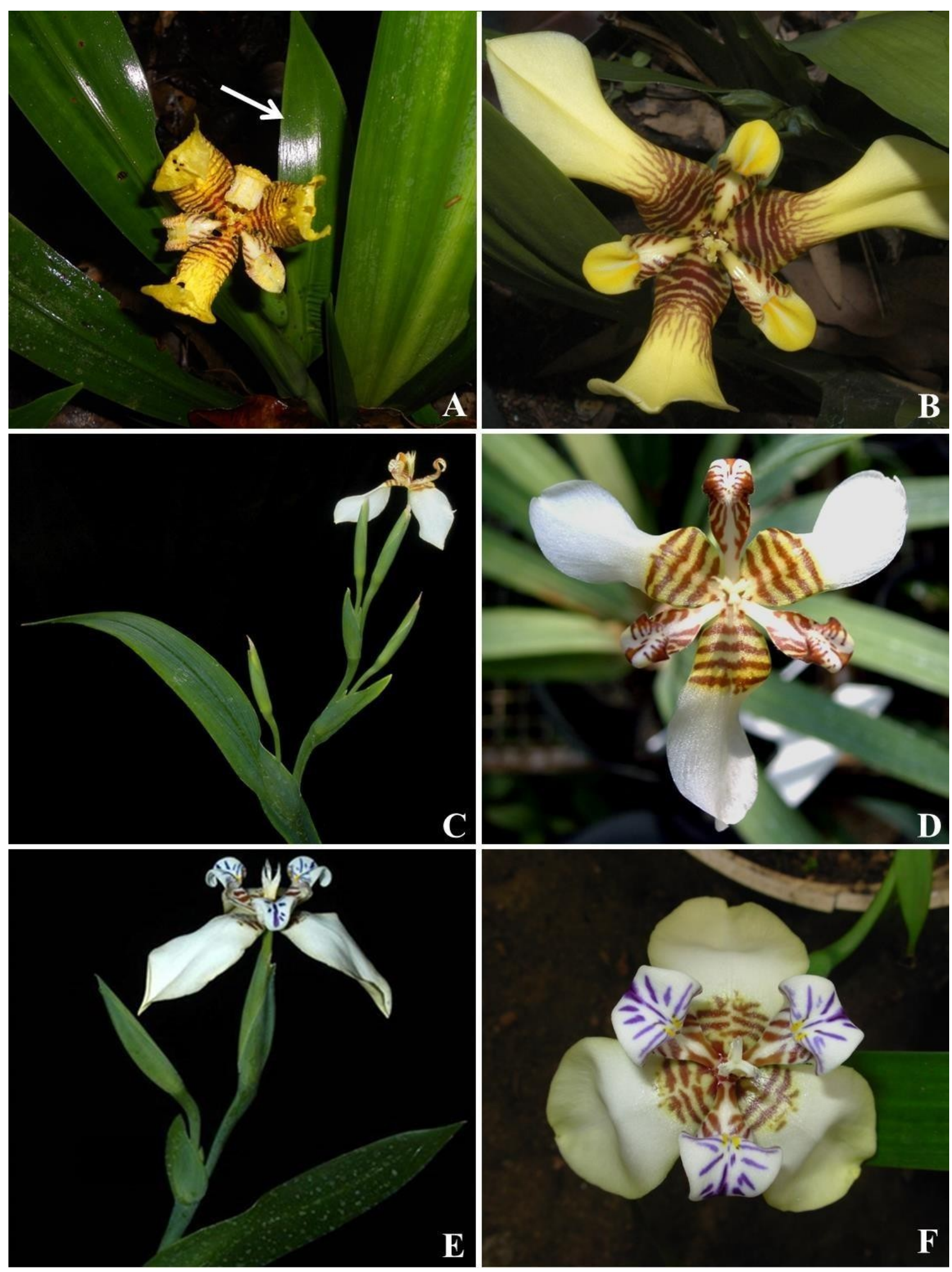

Figura 24. A, B. Neomarica brachypus: A- hábito, com seta indicando a segunda bráctea, com conspícua projeção alada; B- flor, vista frontal. C, D. N. castanemaculata: C- inflorescência; D- flor, vista frontal. E, F. N. eburnea: E- inflorescência; F- flor, vista frontal. (Fotos: A- Lucas Marinho; B, C, E- Volker Bittrich; D, F- André Gil). 


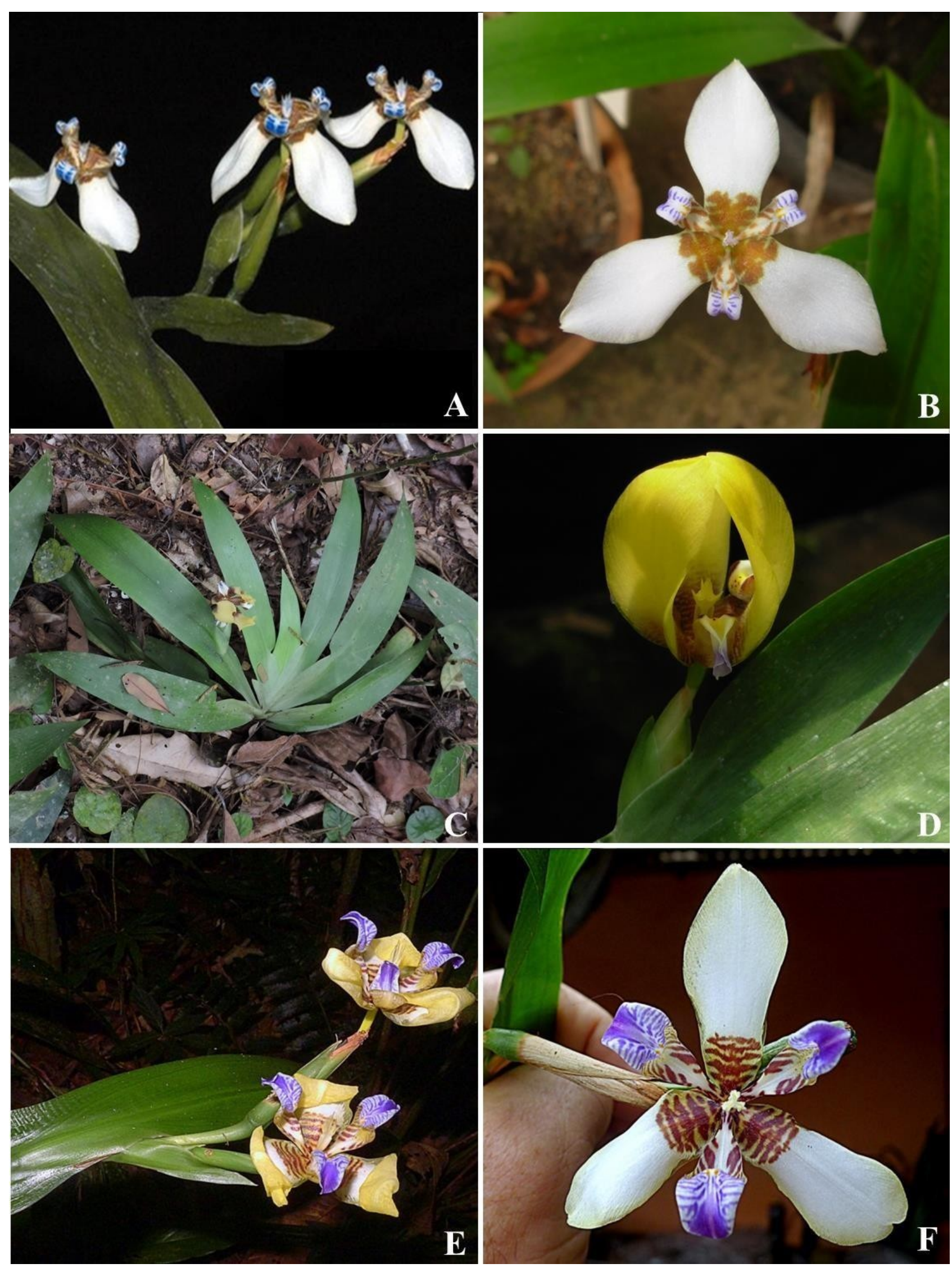

Figura 25. A, B. Neomarica floscella: A- inflorescência; B- flor em vista frontal. C, D. $N$. involuta: C- hábito; D- flor em vista lateral. E, F. N. portosecurensis: E- inflorescência; F- flor em vista frontal. (Fotos: A- Volker Bittrich; B-D- André Gil; E, F- Alex Popovkin). 

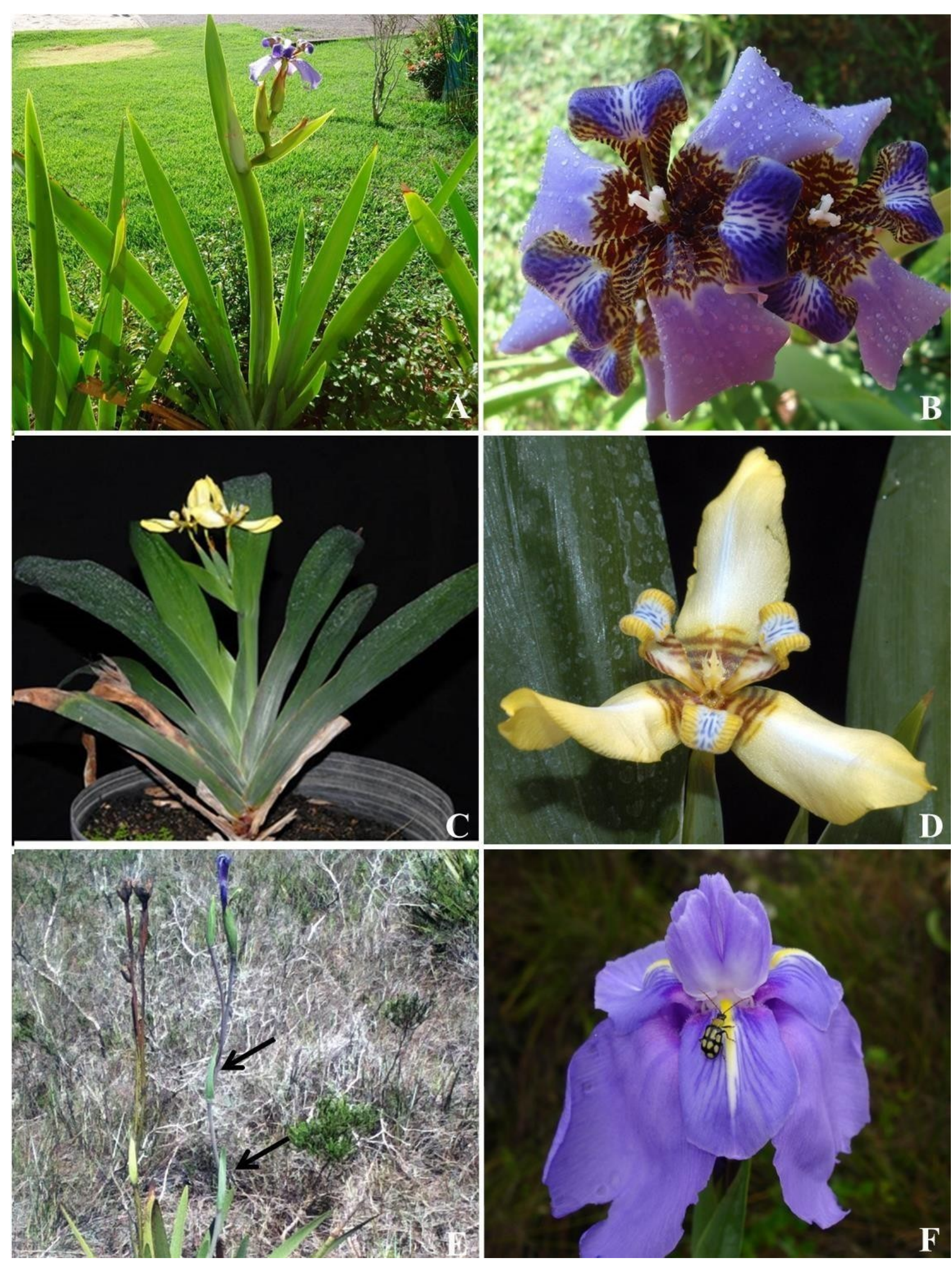

Figura 26. A, B. Neomarica sabinei: A- hábito em cultivo; B- flor em vista frontal. C, D. N. unca: C- hábito em cultivo; D- flor em vista lateral. E, F. Pseudiris speciosa: E- hábito, com setas indicando as brácteas do escapo; F- flor, vista lateral. (Fotos: A, B- P.N. Oliveira; B, C- André Gil; E- Hibert Huaylla; F- Abel Conceição). 

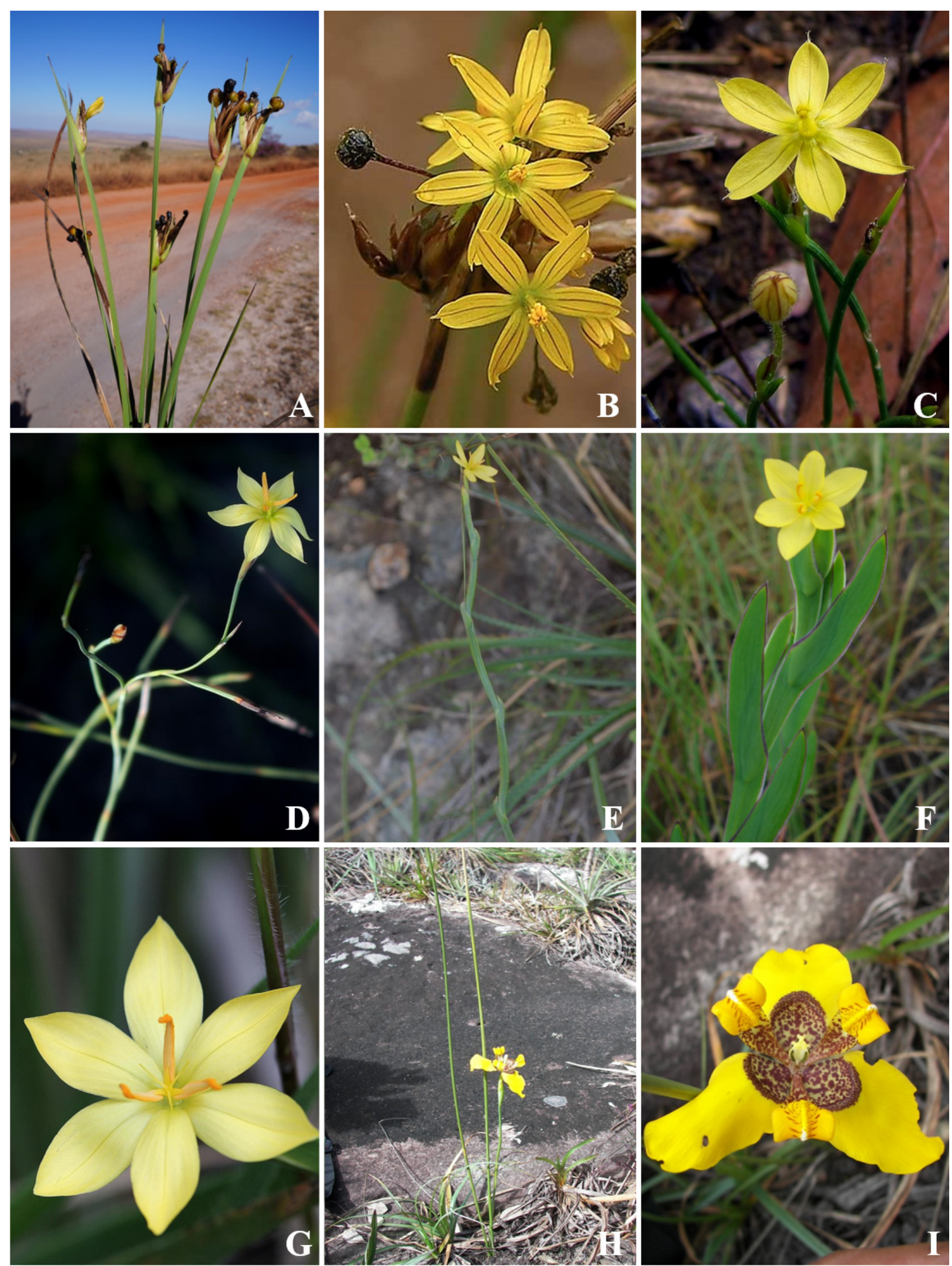

Figura 27. A, B. Sisyrinchium commutatum: A- hábito; B- inflorescência. C. S. luzula: flor; D-G. S. vaginatum: D-F- hábito; G- flor, vista frontal. H, I. Trimezia cathartica: H- hábito; I- flor, vista lateral. (Fotos: A- Efigênia Melo; B- Mauro Peixoto; C, D, G- Maurício Mercadante; E- Ivan Abreu; F- Abel Conceição; H- Hibert Huaylla; I- Pâmela N. Oliveira). 


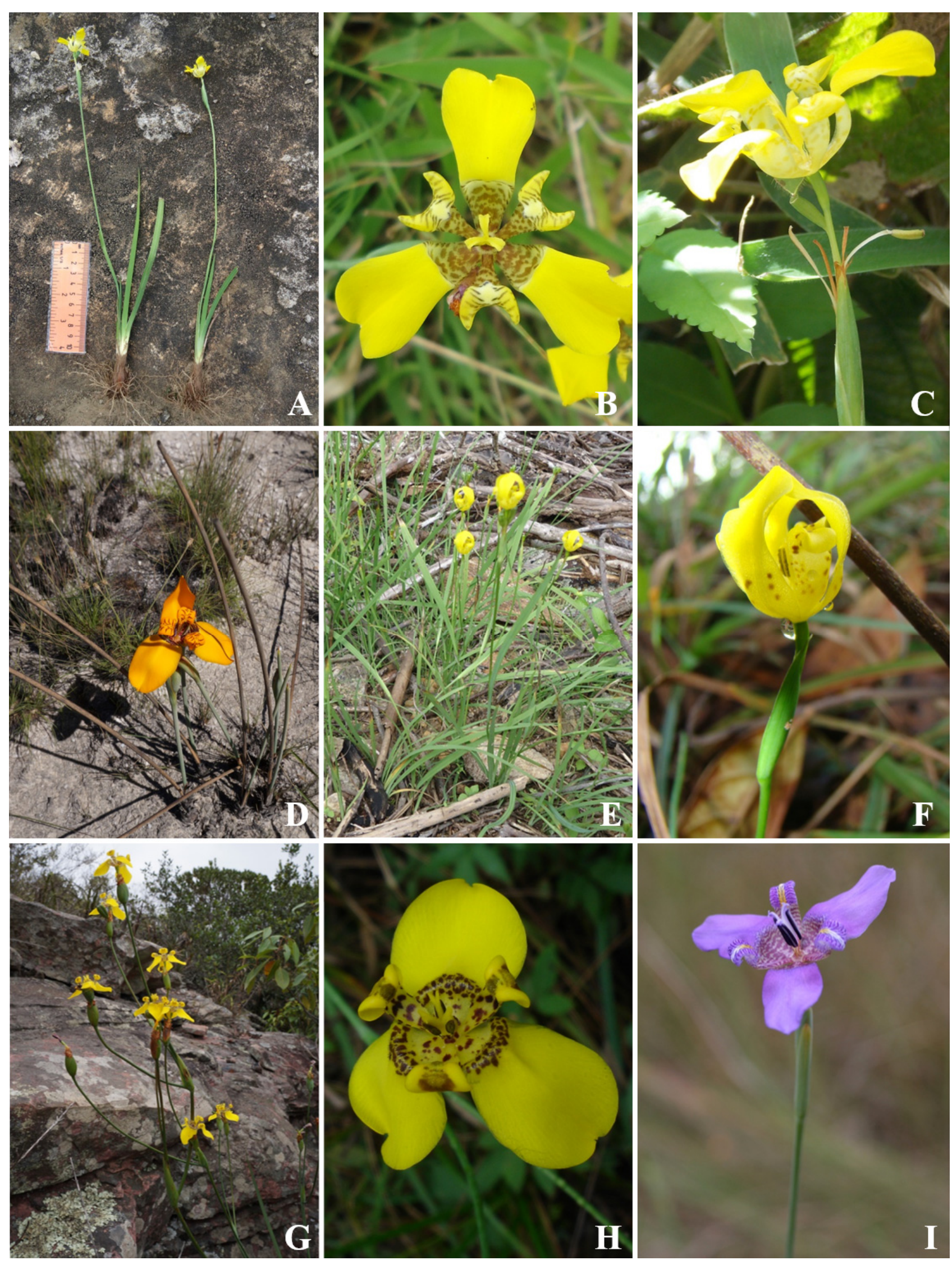

Figura 28. A-C. Trimezia caulosa: A- hábito; B- flor, vista frontal; C- flor, vista lateral. D. T. juncifolia: hábito; E, F. T. martinicensis: E- hábito; F- flor, vista lateral. G, H. T. sincorana: G- inflorescência; H- flor. I. T. violacea: flor. (Fotos: A, B, E, F- Pâmela N. Oliveira; C, G- Efigênia Melo; D- Maurício Mercadante; H- Abel Conceição; I- Richard Winkworth). 
Chukr, N.S. 1992. Flora da Serra do Cipó, Minas Gerais: Iridaceae Boletim de Botânica da Universidade de São Paulo 13: 111131.

Chukr, N.S. \& Capellari Jr., L. 2003. Iridaceae. In: M.G.L. Wanderley, G.J. Shepherd, T.S. Melhem, A.M. Giulietti \& M. Kirizawa (eds), Flora Fanerogâmica do Estado de São Paulo. Vol. 3. RiMa, São Paulo, p. 45-62.

Chukr, N.S. \& Giulietti, A.M. 2001. New combinations in the genus Neomarica (Iridaceae) and its segregation from Trimezia on the basis of morphological features. Novon 11: 376-380.

Chukr, N.S. \& Giulietti, A.M. 2008. Revisão de Trimezia Salisb. ex Herb. (Iridaceae) para o Brasil. Sitientibus série Ciências Biológicas 8: 15-58.

Dias, E.B.A. 2010. Iridaceae. In: T.B. Cavalcanti \& M.F. Batista (orgs), Flora do Distrito Federal, Brasil. Vol. 8. Embrapa Recursos Genéticos e Biotecnologia, Brasília, p. 79-100.

Eggers, L. 2008. A família Iridaceae no Parque Estadual de Itapuã, Viamão, Rio Grande do Sul, Brasil. Revista Brasileira de Biociências 6(3): 167-175.

Eggers, L.; Chukr, N.; Lovo, J. \& Gil, A. 2016. Iridaceae. In: Lista de Espécies da Flora do Brasil. Jardim Botânico do Rio de Janeiro. Disponível em http://floradobrasil.jbrj.gov.br/2010/ FB000136. Acesso em 1 maio 2016.

Gil, A.S.B. 2012. Revisão Taxonômica e Estudos Filogenéticos do Gênero Neomarica s.l. (Iridaceae). Tese de Doutorado em Biologia Vegetal. Universidade Estadual de Campinas.

Gil, A.S.B.; Chukr, N.S.; Giulietti, A.M. \& Amaral, M.C.E. 2008. Pseudiris speciosa, a new genus and species of Trimezieae (Iridoideae, Iridaceae) from Chapada Diamantina, Brazil. Proceedings of the California Academy of Sciences, series 4, 59: 723-729.

Gil, A.S.B.; Chukr, N.S.; Giulietti, A.M. \& Amaral, M.C.E. 2009. Seven new combinations in the genus Neomarica (Trimezieae - Iridaceae). Harvard Papers in Botany 14(2):9799.

Gil, A.S.B.; Bittrich, V. \& Amaral, M.C.E. 2014. Two new species of Neomarica Sprague (Trimezieae - Iridaceae) from Bahia state, northeastern Brazil. Phytotaxa 164: 47-57.
Goldblatt, P. \& Henrich, J.E. 1987. Notes on Cipura (Iridaceae) in South and Central America, and a new specie from Venezuela. Annals of the Missouri Botanical Garden 74: 333-340.

Goldblatt, P. \& Henrich, J.E. 1991. Calydorea Herbert (IridaceaeTigridieae): notes of this New Word genus and reduction to synonymy of Salpingostylis, Cardiostigma, Itysa and Catila. Annals of the Missouri Botanical Garden 78(2): 504-511.

Goldblatt, P. \& Manning, J.C. 2008. The Iris Family: natural history \& classification. Timber Press, Portland.

Goldblatt, P.; Rodriguez, A.; Powell, M.P.; Davies, T.J.; Manning, J.C.; Bank, M. \& Savolainen, V. 2008. Iridaceae 'Out of Australasia'? Phylogeny, biogeography, and divergence time based on plastid DNA sequences. Systematic Botany 33(3): 495-508.

Lindley, J. 1826. A report upon new or rare plants which have flowered in the garden of the Horticultural Society at Chiswick, from its first formation to March 1824. Transactions of the Horticultural Society of London 6: 62-100.

Lorenzi, H. \& Souza, H.M. 1999. Plantas Ornamentais no Brasil: arbustivas, herbáceas e trepadeiras. 2 ed. Instituto Plantarum de Estudos da Flora. Nova Odessa

Lovo, J.; Winkworth, R.C. \& Mello-Silva, R. 2012. New insights into Trimezieae (Iridaceae) phylogeny: what do molecular data tell us? Annals of Botany 110: 689-702.

Oliveira, P.N.; Gil, A.S.B.; Giulietti, A.M.; Oliveira, R.P. \& Amaral, M.C.E. 2016. Neomarica castaneomaculata and $N$. involuta (Iridaceae): two new endemic species from the Atlantic Forest, Brazil. Phytotaxa 286(2): 89-98

Ravenna, P.F. 1977. Neotropical species threatened and endangered by human activity in Iridaceae, Amaryllidaceae and allied bulbous families. In: G.T. Prance \& T.S. Elias (eds), Extinction is Forever. The New York Botanical Garden, New York, p. 257-263.

Ravenna, P.F. 1982. New species and miscellaneous notes in the genus Trimezia (Iridaceae). Wrightia 7(2): 90-95.

Takeuchi, C.; Affonso, P. \& Chukr, N.S. 2008. Levantamento de Iridaceae Juss. no Núcleo Curucutu, Parque Estadual as Serra do Mar, São Paulo. Revista do Instituto Florestal 20(1): 51-63.

\section{LISTA DE EXSICATAS}

Almeida, E.F. 20 (7.6); Almeida, J. 34 (4.6), 180 (4.4); Almeida-Silva, G. 84 (6.4.), 140 (7.2), 145 (5.1.), 196 (7.2), 307 (5.1.); Alves, R.J.V. 4201 (5.1.); Amorim, A.M. 808 (4.4), 4164, 4413 (4.5), 4479 (4.1.), 6267 (7.5), 6443 (4.6), 6506 (4.5), 6575 (4.1.); Andrade, M.J.G. 126 (7.6); Aona, L.Y.S. 2862 (7.5); Assis, E.L.M. 1059 (7.6); Atkins, S. 4880 (6.4.); Azevedo, C. 295 (6.4.); Barreto, K.D. 3348 (7.4); Bautista, H.P. 1233 (7.6), 3877 (7.2), 3954, 4363 (6.4.); Belém, R.P. 2242 (7.5), 3332 (4.7); Borba, E.L. 1841 (5.1.); Borges, R.A.X. 499 (4.1.), 731 (4.8); Brito, J.C. 29 (5.1.); Britto, K.B. 28 (7.6), 36 (7.5); Campos, G.S. 65 (4.7); Cardoso, D. 410 (7.6), 434, 1381 (5.1.), 1426 (4.3.); Carvalho, A.M. 259 (7.3), 308 (7.5), 953, 1056 (7.6), 1601 (4.7), 1981, 2391 (7.6), 3223 (7.5), 3354,3383 (4.4), 3501 (7.5), 3554, 4560 (4.4), 6366 (7.2); Carvalho, G.M. 158 (7.3), 266, 401 (4.6); Carvalho-Sobrinho, J.G. 436 (1.1); Castro, J. 7 (6.4.); Cavalcanti, G. 4 (1.1); Cavalcanti, T.B. 2430 (7.3); Cavalo, G.P. 765 (2.1); Cerati, T.M. 313 (6.4.); Chautems, A. 223 (7.3); Chukr, N.S. 799 (5.1.); Colaço, M. 174 (1.1); Conceição, A.A. 140 (7.2), 769 (5.1.), 844 (7.1), 1690, 1736 (6.4.), 1742 (7.1), 2853 (6.4.), 3129 (7.2), 3271 (6.4.), 3283 (6.2.) 4111 (6.3.); Conceição, S.F. 275 (7.6); Coradin, L. 7708 (7.6); Cordeiro, I. 7539 (6.3.); Cortês, A.L. 62 (2.2), 80 (7.2); Costa, C. 909 (7.5); Costa, G. 10 (6.2.), 95, 130 (6.4.); Cotrim, A. 1653 (6.4.); Daneu, L. 217 (4.6); Davidse, G. 11784 (1.1); Eupunino, A. 16 (7.3), 51 (4.6), 189 (4.7), 275 (7.3), 324 (4.6), 368 (7.3), 477 (4.6); Farinaccio, M.A. 233 (7.4); Farney, C. 299 (4.2); Félix, L.P. 6830 (7.6); Fernandes, B. 1840 (4.2.); Ferreira, M.C. 1022 (7.5); Fiaschi, P. 1912 (4.1.), 2360 (7.5), 2655 (4.6); Fonseca, M.R. 1263 (2.2); Fonseca, W. 267 (7.6); Forzza, R.C. 1323 (7.6); França, F. 1047 (7.5), 2760 (6.1.), 4804 (7.5), 3260 (2.1); Freitas, M. 26 (6.4.); Funch, R. 121 (7.6), 679 (6.4.), 702 (7.2); Furlan, A. 275, 424, 1960 (7.6); Ganev, W. 1808 (6.4.), s.n. HUEFS 13721 (7.6); Gil, A. 156 (4.6), 157 (4.7), 161 (4.3.), 178, 179 (7.3), 180 (4.4), 182 (7.5), 185 (4.7), 186 (4.3.); Giulietti, A.M. 1520 (6.3.), 1542 (7.2), 2065 (2.2), 2551 (4.7); Gonçalves, L.M.C. 171 (6.1.); Gonçalves, J.M. 103 (6.4.); Grillo, 
A.A. 103 (6.2.); Guedes, M.L. 726 (7.6), 4861 (6.4.), 7815 (1.1), 9836 (6.1.), 10748 (6.4.), 10901, 11040 (1.1), 12891 (7.6), 14066 (1.1), 15102 (6.4.), 15133 (2.2), 17473 (4.7), 17624 (6.4.); Hage, J.L. 1738 (2.2); Harley, R.M. 14323 (7.6), 15093 (7.2), 15190, 15479 (6.4.), 15634 (7.2), 15763 (6.3.), 15764 (7.2), 15845, 15846 (6.2.), 15864, 16073, 16809 (6.4.), 17283 (4.7), 17477 (7.5), 17591,17936 (4.7), 18432 (7.3), 18680 (7.6), 18978 (1.1), 20590 (7.6), 20843, 21320 (6.4.), 22451 (7.6), 22576 (6.4.), 25733 (7.2), 25981, 26255, 26326 (6.4.), 26364 (7.2), 26395, 26504, 26655 (6.4.), 26919 (6.3.), 27283 (4.7), 27302 (7.2), 27338, 27401 (6.4.), 27402 (6.3.), 27421 (7.2), 27647 (7.6), 50390 (6.4.), 50904, 51091 (7.2), 51891 (7.6), 52067 (6.4.), 53506 (7.6), 54527 (7.2), 55234,55235 (6.4.), 55719 (3.1.); Hatschbach, G. 39562 (1.1), 47473, 48346 (7.6), 66036 (2.1), 66150, 69990, 75337 (4.7), 75401 (7.6), 78782 (2.1); Hatschbach, J.M.S. 68415 (7.3); Hind, D.J.N. 50028 (7.2), 50898, 50903 (6.4.), 50904 (7.2), 50939 (6.4.); Jardim, J.G. 754 (7.6), 1241 (4.1.), 1809 (7.5), 2536 (7.1), 2565 (6.4.), 2566 (7.2), 3979 (4.4), 4030 (4.8), 4095 (7.3), 4488, 4827 (4.1.); Jesus, N.G. 1482 (4.7); Koehler, S. 17 (7.6); Laessoe, T. 52305 (7.2), 52550, 52552, 52564 (6.4.); Leite, K.R.B. 82 (4.4), 165 (7.6), 227 (6.1.); Lima, J.C. 314 (7.6); Lopes, M.M.M. 600, 745, 1051 (4.5); Lovo, J. 72, 385 (7.6); Lughadha, E.C. 51050 (2.2); Maas, P.J.M. 6978 (7.3), 7002 (4.6); Machado, M. 124 (2.1); Marinho, L.C. 466 (6.4.) Martinelli, G. 5354 (7.6); Martini, A. 38 (7.5); Matos, E. 3345,3346 (7.3); Matos, E.N. 217, 402, 1004 (4.7); Mattos-Silva, L.A. 493 (7.5), 1633 (7.6), 1735 (7.3), 1997 (4.7), 2937 (7.5), 3244,3517 , 3596 (7.3), 4116, 4139 (4.1.), 4551 (7.5), 4738 (7.3), 16122 (7.6), 17477 (7.5), 26999 (7.6); Meireles. J.E. 699 (7.6); Melo, E. 1660 (5.1.), 1735 (6.4.), 3002 (7.6), 3327 (6.4.), 3329, 3445 (7.5), 4716 (1.1), 5366 (6.4.), 6197 (1.1), 7929 (6.4.), 8584 (4.3.), 9416 (1.1), 15120 (6.4.); Melo-de-Pinna, G.F. 134, 135 (7.6); Mendonça, R.C. 1562 (7.4); Miranda, E.B. 963 (1.1); Moraes, M.D. 506 (7.2); Mori, S.A. 9543 (1.1), 9656 (4.7), 10048 (6.1.), 10159 (7.5), 10729 (7.6), 10849 (4.6), 10973 (4.7), 11772 (7.5), 13204 (7.6); Neves, S.P.S. 190 (7.2), 441 (6.2.); Noblick, L.R. 1616 (7.5), 1259 (6.4.), 2554 (7.5), 4257 (6.4.); Nonato, F.R. 864 (7.6); Nunes. T.S. 338 (7.6), 966 (1.1), 1412 (4.7); Oliveira, P.N. 108 (6.2), 109 (7.2), 112 (6.4), 113 (4.7.), 114 (4.6), 115 (7.3), 116 (4.4.), 117 (7.5), 118 (7.6.), 119 (7.5.), 120 (2.1.), 122 (1.1); Oliveira, R.P. 503 (2.1); Orlandi, R.P. 711 (7.6); Paixão, J.L. 1117 (7.5); Passos, L. 4959 (7.2), 5655 (7.6); Paula-Souza, J. 5075 (7.2), 9924 (1.1); Perdiz, R.O. 284 (4.5); Pinheiro, R.S. 1474 (7.3), 1823 (4.4), 2107 (4.7); Pirani, J.R. 51470 (6.4.), 7484 (6.1.); Pirani, L.R. 5404 (7.6); Popovkin, A.V. 153, 237 (7.5), 614 (2.1), 1122 (3.1.); Queiroz, L.P. 70,343 (1.1), 403 (7.5), 656 (7.6), 1141 (4.7), 3496 (7.6), 4387 (6.2.), 4962 (7.2), 5132 (7.3), 5351 (7.5), 6460 (4.7), 6632 (7.5), 7693, 9330, 9396, 9746, 9771 (7.6), 12303 (1.1), 12307 (7.5), 13150 (7.6), 14443 (2.1); Rapini, A. 1319 (7.5), 1521, 2018 (6.4.); Ravenna, P. 3349 (4.8); Ribeiro, A.J. 45 (7.5), 47 (6.2.); Ribeiro, P.L. 90 (7.6); Ribeiro-Filho, A.A. 214 (5.1.); Roque, N. 3472 (6.1.); Saavedra, M.M. 929 (7.5); Sano, P.T. 14876 (7.2); Santana, J.S. 42 (4.7); Sant'Ana, S.C. 870 (4.4); Santos, A.K.A. 33 (6.4.); Santos, F.S. 78 (4.6), 268 (4.7), 284 (3.1.), 430 (7.3); Santos, T.S. 1924 (7.3), 1954 (4.6), 2731 (4.7), 3979 (7.3), 4386 (4.7); Sellow s.n. HUEFS 112416 (6.4.); Senna, L.R. 74 (6.4.); Silva, N.C.B. 56 (6.4.); Silva-Castro, M.M. 1202 (7.5); Smidt, E.C. 219 (6.4.), 257 (5.1.), 297 (7.2), 347, 348,349 (5.1.), 604 (7.6); Souza, E.B. 1582 (1.1); Souza, E.R. 71 (7.6); Souza, V.C. 22661 (6.4.), 23003 (2.2), 5214 (7.6), 22682, 22694 (7.2), 22893 (7.6), 30726 (7.5); Stannard, B. 51099 (6.4.), 51774 (2.2), 51891 (7.6), 6888 (6.4.); Stradmann, M.T.S. 436 (7.2), 535 (4.7); Thomas, W.W. 9973 (4.7), 11230 (4.8), 13402 (4.4); Vageler, H. 948 (4.7); van den Berg, C. 949 (4.2.), 1009 (7.5), 1262 (7.4); Vanilda, M. 166 (4.7); Vinha, S.G. 71 (7.5), 166 (4.7), 219 (7.5); Viollati, L.G. 248 (2.2); Walter, B.M.T. (7.2); Xavier, A.B. 230 (6.4.). 